Reagan, M.K., Pearce, J.A., Petronotis, K., and the Expedition 352 Scientists, 2015

Proceedings of the International Ocean Discovery Program Volume 352

publications.iodp.org

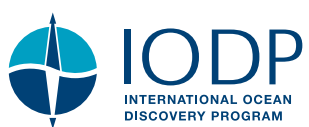

\title{
Contents
}

doi:10.14379/iodp.proc.352.101.2015

\section{Expedition 352 summary $^{1}$}

CrossMark \& click for updates

M.K. Reagan, J.A. Pearce, K. Petronotis, R. Almeev, A.A. Avery, C. Carvallo, T. Chapman, G.L. Christeson, E.C. Ferré, M. Godard, D.E. Heaton, M. Kirchenbaur, W. Kurz, S. Kutterolf, H.Y. Li, Y. Li, K. Michibayashi, S. Morgan, W.R. Nelson, J. Prytulak, M. Python, A.H.F. Robertson, J.G. Ryan, W.W. Sager, T. Sakuyama, J.W. Shervais, K. Shimizu, and S.A. Whattam ${ }^{2}$

Keywords: International Ocean Discovery Program, IODP, JOIDES Resolution, Expedition 352, Izu-Bonin-Mariana fore arc, Site U1439, Site U1440, Site U1441, Site U1442, subduction initiation, magma genesis, ophiolites, basalt, boninite, high-magnesium andesite, volcanic rocks, dikes, drill core

\author{
1 Abstract \\ 2 Background \\ 8 Scientific objectives \\ 9 Principal results \\ 23 Preliminary scientific assessment \\ 31 References
}

\begin{abstract}
The objectives for International Ocean Discovery Program Expedition 352 were to drill through the entire volcanic sequence of the Bonin fore arc to

1. Obtain a high-fidelity record of magmatic evolution during subduction initiation and early arc development,

2. Test the hypothesis that fore-arc basalt lies beneath boninite and understand chemical gradients within these units and across the transition,

3. Use drilling results to understand how mantle melting processes evolve during and after subduction initiation, and

4. Test the hypothesis that the fore-arc lithosphere created during subduction initiation is the birthplace of suprasubduction zone ophiolites.
\end{abstract}

Expedition 352 successfully cored $1.22 \mathrm{~km}$ of igneous basement and $0.46 \mathrm{~km}$ of overlying sediment, providing diverse, stratigraphically controlled suites of fore-arc basalt (FAB) and boninites related to seafloor spreading and earliest arc development. FAB and related rocks were recovered at the two deeper water sites (U1440 and U1441) and boninites and related rocks were recovered at the two sites (U1439 and U1442) drilled upslope to the west. FAB lavas and dikes are depleted in high-field strength trace elements such as $\mathrm{Ti}$ and $\mathrm{Zr}$ relative to mid-ocean-ridge basalt but have relatively diverse concentrations of trace elements because of variation in degrees of melting, and potentially, the amount of subducted fluids involved in their genesis. FAB are relatively differentiated, and average degree of differentiation increases with depth, which is consistent with crystal fractionation in a persistent magma chamber system beneath a spreading center. Holes U1439C and U1442A yielded entirely boninite differentiation series lavas that generally become more primitive and have lower $\mathrm{TiO}_{2}$ concentrations upward. The presence of dikes at the base of the sections at Sites U1439 and U1440 provides evidence that boninitic and FAB lavas are both underlain by their own conduit systems and, therefore, that FAB and boninite group lavas are likely offset more horizontally than vertically. We thus propose that seafloor spreading related to subduction initiation migrated from east to west after subduction initiation and during early arc development. Initial spreading was likely rapid, and an axial magma chamber was present. Melting was largely decompressional during this period, but subducted fluids affected some melting. As subduction continued and spreading migrated to the west, the embryonic mantle wedge became more depleted and the influence of subducted constituents dramatically increased, causing the oceanic crust to be boninitic rather than tholeiitic. The general decrease in fractionation upward in the boninite holes reflects the eventual disappearance of persistent magma chambers, either because spreading rate was decreasing with distance from the trench or because spreading was succeeded by off-axis magmatism trenchward of the ridge. The extreme depletion of the sources for all boninitic lavas was likely related to the incorporation of mantle residues from FAB generation. This mantle depletion continued during generation of lower silica boninitic magmas, exhausting clinopyroxene from the mantle such that the capping high-silica, low-titanium boninites were generated from harzburgite.

Additional results of the cruise include recovery of Eocene to recent deep-sea sediment that records variation in sedimentation rates with time resulting from variations in climate, the position of the carbonate compensation depth, and local structural control. Three phases of highly explosive volcanism (latest Pliocene to Pleistocene, late Miocene to earliest Pliocene, and Oligocene) were identified, represented by 132 graded air fall tephra layers. Structures found in the cores and reflected in seismic profiles show that this

\footnotetext{
${ }^{1}$ Reagan, M.K., Pearce, J.A., Petronotis, K., Almeev, R., Avery, A.A., Carvallo, C., Chapman, T., Christeson, G.L., Ferré, E.C., Godard, M., Heaton, D.E., Kirchenbaur, M., Kurz, W., Kutterolf, S., Li, H.Y., Li, Y., Michibayashi, K., Morgan, S., Nelson, W.R., Prytulak, J., Python, M., Robertson, A.H.F., Ryan, J.G., Sager, W.W., Sakuyama, T., Shervais, J.W., Shimizu, K., and Whattam, S.A., 2015. Expedition 352 summary. In Reagan, M.K., Pearce, J.A., Petronotis, K., and the Expedition 352 Scientists, Izu-Bonin-Mariana Fore Arc. Proceedings of the International Ocean Discovery Program, 352: College Station, TX (International Ocean Discovery Program). http://dx.doi.org/10.14379/iodp.proc.352.101.2015

2 Expedition 352 Scientists' addresses.

MS 352-101: Published 29 September 2015
} 
area had periods of normal, reverse, and strike-slip faulting. Finally, basement rock $P$-wave velocities were shown to be slower than those observed during logging of normal ocean crust sites.

\section{Background Izu-Bonin-Mariana system}

The Izu-Bonin-Mariana (IBM) system is the type locality for studying oceanic crustal accretion immediately following subduction initiation. It is sufficiently old that it carries a full record of the evolution of crustal accretion from the start of subduction to the start of normal arc volcanism and sufficiently young that the key features have not been excessively disturbed by subsequent erosion or deformation. Intraoceanic arcs are built on oceanic crust and are sites of formation of juvenile continental crust (Rudnick, 1995; Tatsumi and Stern, 2006). Most active intraoceanic arcs are located in the western Pacific. Among these, the IBM system stands out as a natural scientific target. This predominantly submarine convergent plate boundary is the result of $\sim 52 \mathrm{My}$ of subduction (Ishizuka et al., 2011; Reagan et al., 2013) of the Pacific plate beneath the eastern margin of the Philippine Sea plate. Stretching for $2800 \mathrm{~km}$ from the Izu Peninsula, Japan, to Guam, USA, the IBM system (summarized in Stern et al., 2003) has been extensively surveyed and has become an important natural laboratory for International Ocean Discovery Program (IODP) expeditions (Figure F1) aimed at understanding subduction initiation, arc evolution, and continental crust formation. A scientific advantage of studying the IBM system is its broad background of scientific investigation resulting from its designation as a focus site by the US National Science Foundation MARGINSSubduction Factory experiment and similar efforts in Japan. We know when subduction and arc construction began at the IBM system, even if the precise paleogeography is controversial, and there is a good time-space record of crustal development.

\section{Petrologic evolution}

The petrologic evolution of early stage magmatism in the IBM arc has been reconstructed mainly based on volcanic sections that are exposed on the fore-arc islands (Bonin Islands and Mariana Islands) and that have been recovered from Deep Sea Drilling Project (DSDP) and Ocean Drilling Program (ODP) fore-arc drill sites. Re-

Figure F1. Regional map of the Izu-Bonin-Mariana (IBM) system showing the location of sites from Expeditions 350, 351, and 352.

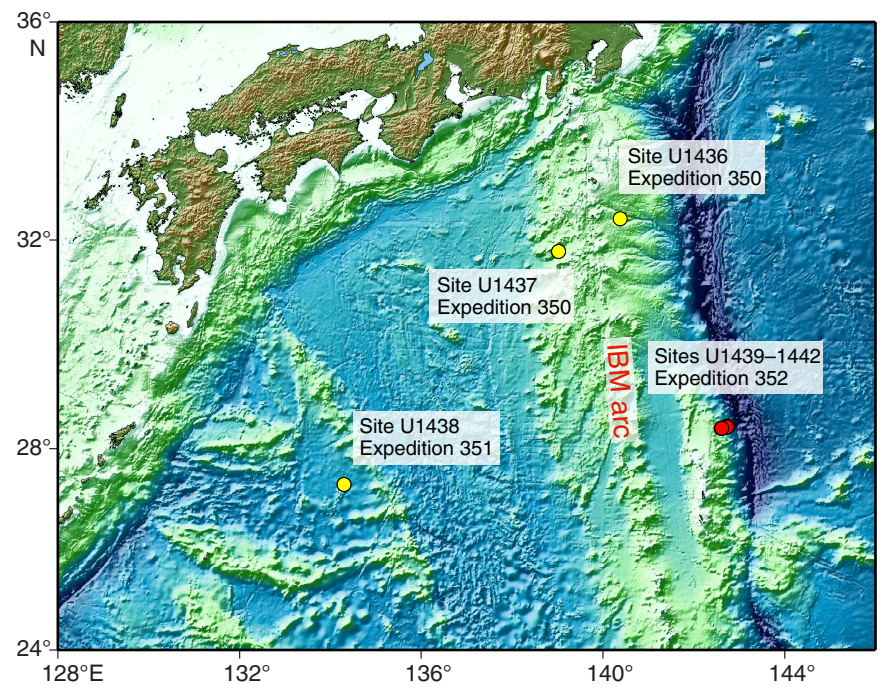

cent dredging and submersible studies have provided additional information. Consequently, we were able to predict the sequence of magmas likely to characterize the drill site and its surrounding region, which developed after subduction initiation and prior to establishment of a stable magmatic arc to the west by the late Eocene. The physical evolution of the fore arc and its associated lavas reflects the reorganization of mantle convection and slab-derived fluid flow in response to the changing behavior of the sinking Pacific plate. This evolution, from initial seafloor spreading and eruption of mid-ocean-ridge basalt (MORB)-like tholeiites to eruption of boninites to fixing of the magmatic arc $\sim 150 \mathrm{~km}$ west of the trench (separated by a broad, dead fore arc), took 7-8 million years (Ishizuka et al., 2011). The process is reflected in the succession of igneous rocks of the Bonin Ridge, which is described in greater detail below and depicted in the time-space diagram (Figure F2).

\section{Early subduction-related volcanism}

Diving and dredging on the fore-arc slope east of the Bonin Ridge and south of Guam recovered basaltic rocks from stratigraphic levels below boninite. These basalts have chemical compositions that are similar to those of normal MORB (N-MORB). However, they are not identical, and hence the term "fore-arc basalt (FAB)" was coined by Reagan et al. (2010) to highlight their distinctive setting and to emphasize that, in detail, FAB is a different magma type from MORB. Most of the reliable ${ }^{40} \mathrm{Ar} /{ }^{39} \mathrm{Ar}$ ages and $\mathrm{U}-$ $\mathrm{Pb}$ zircon ages of FAB are identical within error in both locations and indicate that FAB magmatism occurred at $~ 51-52 \mathrm{Ma}$, preceding boninite eruption by 2-4 million years (Ishizuka et al., 2011; Reagan et al., 2013). Lavas with compositions transitional between FAB and boninites from DSDP Leg 60 Site 458 in the Mariana fore arc were dated at $49 \mathrm{Ma}$ (Cosca et al., 1998). FAB and related gabbros are thought to relate to the first magmas produced as the IBM subduction zone began to form (Reagan et al., 2010).

Geochemical data show that FAB magmas have light rare earth element-depleted rare earth element (REE) patterns, indicating derivation from a moderately depleted lherzolitic upper mantle, similar to that responsible for generating MORB (Figure F3). FAB in the IBM, however, has low Ti/V (14-16), a diagnostic ratio (Shervais, 1982) that distinguishes FAB from subducting Pacific MORB ( Ti/V = 26-32) and from Philippine Sea back-arc lavas ( Ti/V = 1725) (Figure F4). Chemically and petrographically, Bonin Ridge FAB is indistinguishable from Mariana FAB. This implies that FAB tholeiitic magmatism was associated with fore-arc spreading along the length of the IBM arc. Low concentrations of incompatible elements and low trace element ratios such as Ti/V imply that FAB magmas were derived from more depleted mantle and/or were larger degree mantle melts than typical Philippine Sea MORB (Reagan et al., 2010).

$\mathrm{Pb}$ isotopic compositions of FAB from the Bonin fore arc show that they are, like other IBM arc and back-arc magmas, derived from a mantle with Indian Ocean characteristics, as demonstrated by high $\Delta 8 / 4 \mathrm{~Pb}$ compared to Pacific MORB (Ishizuka et al., 2011). Isotopic characteristics indicate some differences between the mantle sources of Philippine Sea MORB and FAB, including distinctly higher ${ }^{87} \mathrm{Sr} /{ }^{86} \mathrm{Sr}$ and ${ }^{206} \mathrm{~Pb} /{ }^{204} \mathrm{~Pb}$ (Figure F5), which may imply the presence of lithospheric mantle with inherited enrichment (Parkinson et al., 1998). Most significantly, incompatible trace elements derived from subducted crust do not unambiguously affect the source region of most $\mathrm{FAB}$, although some $\mathrm{FAB}$ lavas from the Mariana fore arc have $\mathrm{Pb}$ isotopic compositions consistent with a weak influence of subducted Pacific crust (Reagan et al., 2010). Differences in 
Figure F2. Compilation of ${ }^{40} \mathrm{Ar} /{ }^{39} \mathrm{Ar}, \mathrm{K} / \mathrm{Ar}$, and U-Pb zircon dating results for Eocene igneous rocks from the IBM fore arc, modified after Ishizuka et al. (2011). Expedition 352 focuses on the detailed stratigraphy of the 7-8 My period between subduction initiation and the start of "normal" arc volcanism. Data sources: Meijer et al. (1982), Cosca et al. (1998), Reagan et al. (2008, 2013), Kaneoka et al. (1970), Ishizuka et al. (2006, 2011). HMA = high-magnesium andesite.

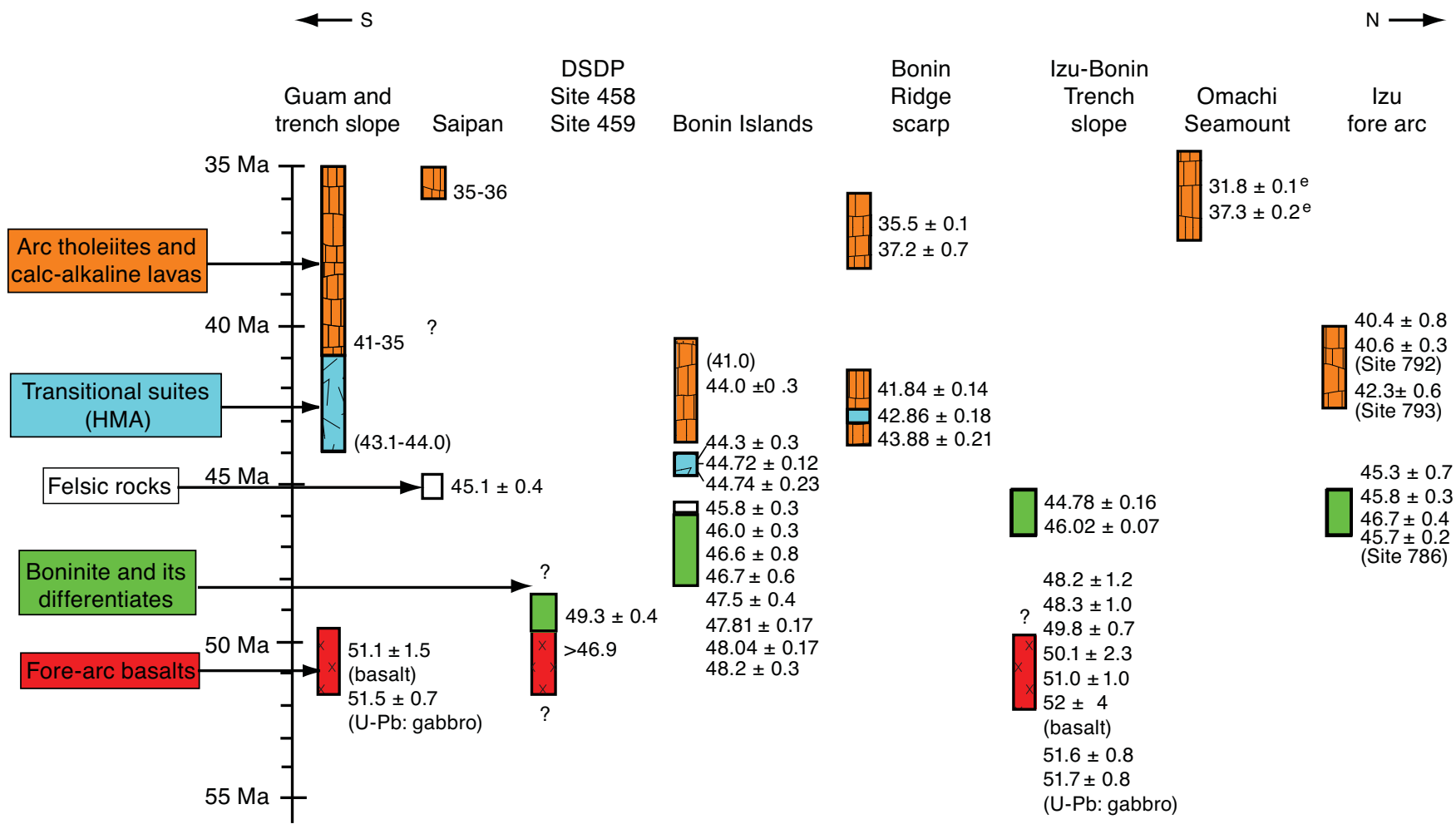

Figure F3. Variations in REE patterns in the Bonin fore arc following subduction initiation. Note the recently discovered MORB-like patterns of the first volcanic products, the fore-arc basalt, and the contrast with the later Ushaped boninite patterns. Expedition 352 research will obtain complete information on gradations within and between these units. Plot taken from Ishizuka et al. $(2006,2011)$.

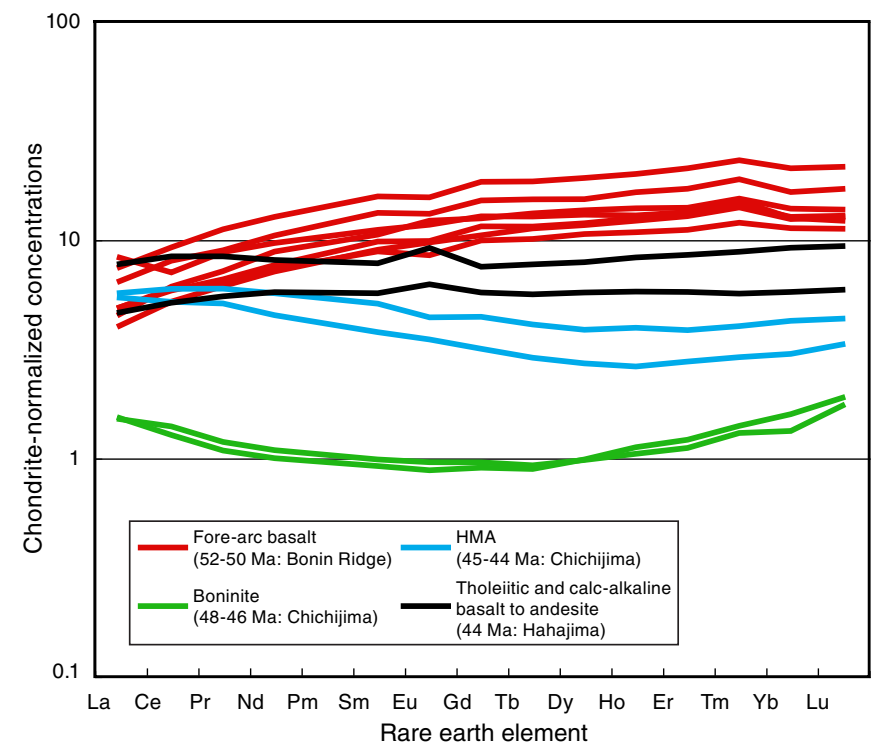

isotopic and trace element characteristics between IBM FAB and MORB including that from the Philippine plate strongly imply that FAB do not represent preexisting ocean basin or back-arc basin crust trapped prior to subduction initiation, as originally concluded
Figure F4. V-Ti systematics (Shervais, 1982) for the lavas erupted following subduction initiation. Note that the earliest lavas to erupt following subduction initiation are distinct from MORB and from later boninites. These are, however, isolated outcrops. Plot taken from Ishizuka et al. $(2006,2011)$.

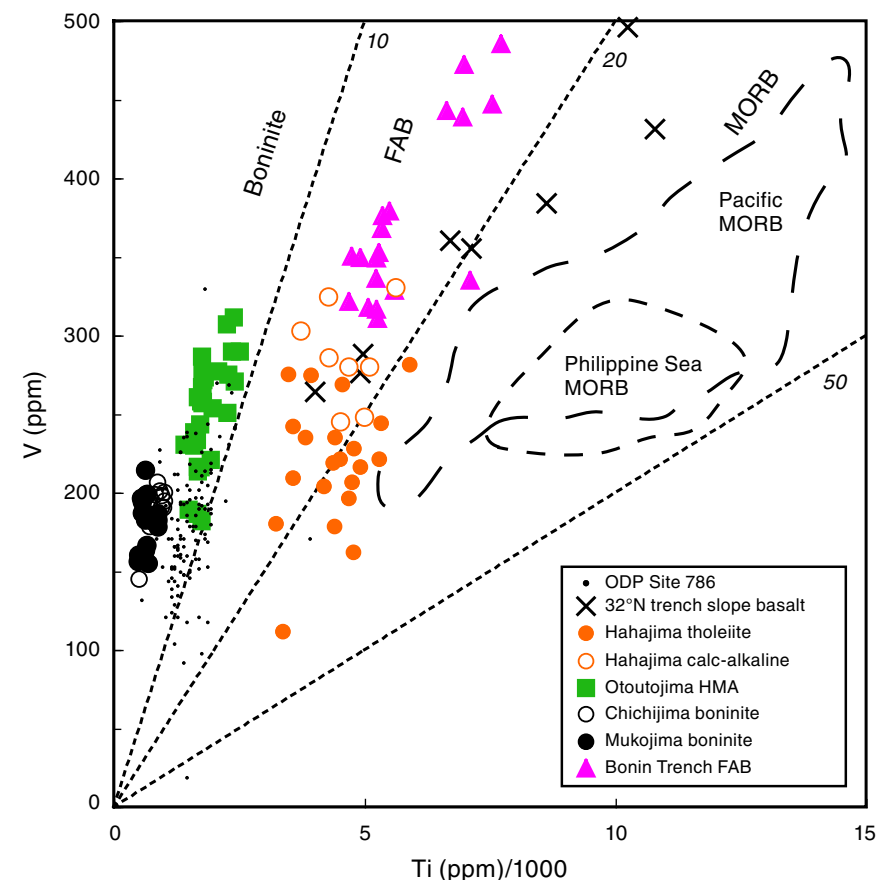

by Johnson and Fryer (1990) and DeBari et al. (1999) for MORB-like tholeiites recovered from the Mariana and Izu inner trench walls. 
Figure F5. Isotopic compositions highlight the complex variations in lava chemistry following subduction initiation. A complete stratigraphy will enable better interpretation of these data in terms of variations in mantle sources and subduction components following subduction initiation. Data from Ishizuka et al. $(2006,2011) . K P R=$ Kyushu-Palau Ridge, NHRL = Northern Hemisphere reference line. Solid line = Quaternary Izu-Bonin front compositions, dashed line $=$ Oligocene arc (KPR) compositions.
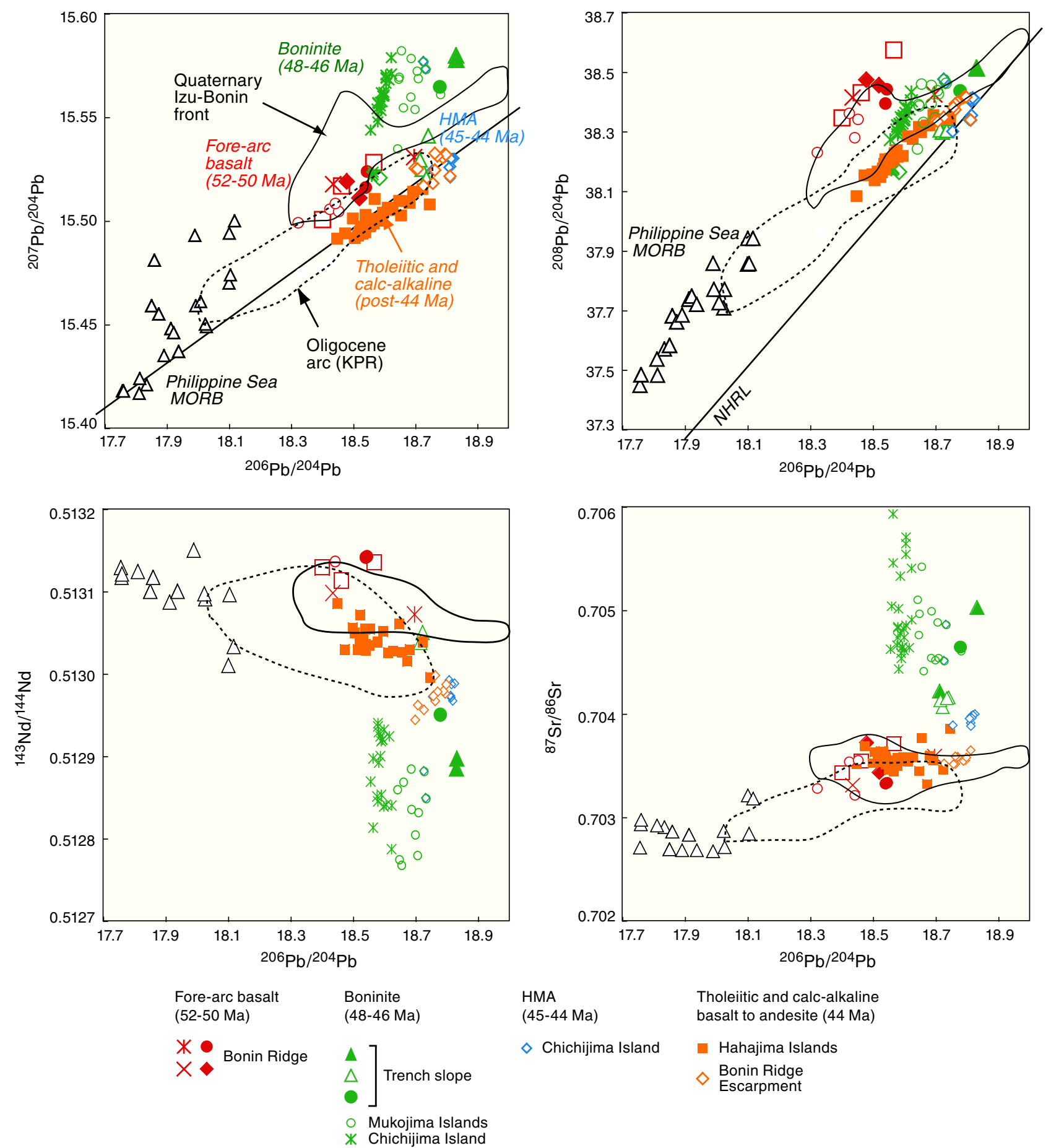

HMA (45-44 Ma)

$\diamond$ Chichijima Island basalt to andesite (44 Ma)

- Hahajima Islands

$\diamond \begin{aligned} & \text { Bonin Ridge } \\ & \text { Escarpment }\end{aligned}$
Lavas with compositions that transition upward between FAB and boninite were recovered at Sites 458 and 459 in the Mariana fore arc and illustrate that FAB and boninite are genetically linked (Reagan et al., 2010). The oldest of these lavas have REE patterns similar to those of MORB but are more enriched in silica and have higher concentrations of "fluid-soluble" elements such as $\mathrm{K}, \mathrm{Rb}, \mathrm{U}$, and $\mathrm{Pb}$ than $\mathrm{FAB}$. These lavas also have $\mathrm{Pb}$ isotopic compositions that are more similar to lavas from the Pacific than to those from the Indian plate, supporting the contention that subducted fluids were involved in their genesis. The youngest lavas at Site 458 are strongly depleted in REE, somewhat resembling boninites but less magnesian and more calcic.

Boninite volcanism follows FAB volcanism as an integral part of the evolution of the nascent subduction zone. The type locality of 
boninite is in the Bonin (Ogasawara) Islands, an uplifted segment of the IBM fore arc. Boninites are better exposed on the Bonin Islands than anywhere else in the world, particularly on the island of Chichijima. ${ }^{40} \mathrm{Ar} /{ }^{39} \mathrm{Ar}$ dating indicates that boninitic volcanism on Chichijima took place briefly during the Eocene, between 46 and $48 \mathrm{Ma}$ (Ishizuka et al., 2006). A slightly younger volcanic succession is exposed along the Bonin Ridge, including $44.74 \pm 0.23$ Ma boniniteseries lavas from the Mikazukiyama Formation, the youngest volcanic sequence on Chichijima, and $44.0 \pm 0.3 \mathrm{Ma}$ tholeiitic to calcalkaline andesite from Hahajima. Four submersible Shinkai 6500 dives on the Bonin Ridge Escarpment mapped an elongate constructional volcanic ridge atop the escarpment and recovered fresh andesitic clasts from debris flows along the northern segment of the ridge; they also recovered high-magnesium andesite lava blocks from the escarpment northwest of Chichijima. Three samples of andesite collected from the Bonin Ridge Escarpment range in age from $41.84 \pm 0.14$ to $43.88 \pm 0.21 \mathrm{Ma}$ (Ishizuka et al., 2006).

Boninites from the Bonin Islands are characterized by high $\mathrm{MgO}$ at given $\mathrm{SiO}_{2}$ concentrations, low high-field strength elements, low $\mathrm{Sm} / \mathrm{Zr}$, low REE, and a U-shaped REE pattern (Figure F3). These are "low-calcium boninites" (Crawford et al., 1989) and can be explained by low-pressure melting of depleted harzburgite that was strongly affected by slab flux. These boninites are isotopically characterized by high $\Delta 7 / 4 \mathrm{~Pb}$, high ${ }^{87} \mathrm{Sr} /{ }^{86} \mathrm{Sr}$, and low ${ }^{143} \mathrm{Nd} /{ }^{144} \mathrm{Nd}$ relative to local MORB and FAB sources (Figure F5). In contrast to the FAB mantle source, which was not much affected by subduction-related fluids or melts, the boninite magma source manifests a major contribution from subducted pelagic sediment and oceanic crust. The boninites are also distinct from $~ 44$ Ma lavas exposed on Hahajima Island and recovered by Shinkai 6500 diving on the Bonin Ridge Escarpment (Ishizuka et al., 2006). Younger boninite-series lavas from the Mikazukiyama Formation on Chichijima and the Bonin Ridge Escarpment are more similar to relatively enriched, less Ca depleted boninitic lavas from ODP Site 786 in the Izu-Bonin fore arc (Pearce et al., 1992) and Guam (Hickey-Vargas and Reagan, 1987), including having higher $\mathrm{Sm} / \mathrm{Zr}$ at a given $\mathrm{Zr}$ content and higher REE and Ti concentrations compared to Chichijima boninite (cf. Taylor et al., 1994). These younger boninite-series lavas are isotopically distinct from the boninites (Figure F5) because they have a lower proportion of subducted versus mantle constituents.

Post-45 Ma, tholeiitic to calc-alkaline andesites from the Bonin Ridge and $~ 45$ Ma rhyolites from Saipan (Reagan et al., 2008) exhibit strong characteristics of arc magmas: they are depleted in $\mathrm{Nb}$ and enriched in fluid-mobile elements such as $\mathrm{Sr}, \mathrm{Ba}, \mathrm{U}$, and $\mathrm{Pb}$. These characteristics indicate that, by $45 \mathrm{Ma}$, near-normal configurations of mantle flow and melting, as well as subduction-related fluid formation and metasomatism, were established for this part of the IBM arc. The Bonin Ridge Escarpment, Mikazukiyama Formation, and Hahajima andesites thus represent a transitional stage from the waning stages of fore-arc spreading (represented by FAB and perhaps boninites) and the stable, mature arc that developed in the late Eocene. These orthopyroxene-bearing, high-magnesium tholeiitic to calc-alkaline andesites erupted along the Bonin Ridge Escarpment as the arc magmatic axis localized and retreated from the trench. Post-45 Ma andesites (and basalts) do not show the influence of pelagic sediment melt from the slab (Figure F5). Instead, the mantle source seems to have only been affected by hydrous fluid derived mainly from subducted altered oceanic crust.

Overall, the geochemical and isotopic characteristics of the IBM arc along its entire length appear to have evolved in tandem with the formation of a new subduction zone and a new mantle flow regime:
1. Initial decompression melting with little to no slab flux, producing MORB-like basalt and fore-arc spreading (51-52 Ma),

2. Mixing of fluids or melts from subducted sediments and oceanic crust into an extremely depleted (harzburgitic) mantle to generate boninites (49-45 Ma), and

3. Continued influx of hydrous fluid input into increasingly fertile lherzolitic mantle to generate tholeiitic and calc-alkaline magma (post-45 Ma), marking the time when a mature, stable arc magmatic system was finally established (Ishizuka et al., 2006, 2011).

Note however that although we have established a general volcanic stratigraphy for the IBM fore arc, it is a composite stratigraphy based on dredging, submersible grab sampling, and coring at widely spaced localities. There is no reference stratigraphic section to check this subduction initiation stratigraphy and, in particular, to identify the nature of the boundaries between the units and demonstrate that units have not been missed. Defining this stratigraphic section is the aim of this expedition.

\section{Tectonic evolution}

It has been generally accepted (Bloomer et al., 1995; Pearce et al., 1999; Stern, 2004; Hall et al., 2003) that the IBM subduction zone began as part of a hemispheric-scale foundering of old, dense lithosphere in the western Pacific (Figure F6). The beginning of large-scale lithospheric subsidence, not true subduction but its precursor, is constrained to predate the 51-52 Ma age of igneous basement of the IBM fore arc (Bloomer et al., 1995; Cosca et al., 1998; Ishizuka et al., 2006). The sequence of initial magmatic products is similar everywhere the fore arc has been sampled, implying a dramatic episode of asthenospheric upwelling and melting associated with magmatism and seafloor spreading over a zone that was perhaps hundreds of kilometers broad and thousands of kilometers long. It is clear from the extensive geochronology for IBM fore-arc rocks that this episode took place $\sim 52$ million years ago and was followed by a period of shallow hydrous melting through $\sim 44-45$ million years ago (Figure F2). Expedition 352 drilling sampled these parts of the tectonic history of the IBM arc.

Interestingly, these time-space trends in IBM fore-arc composition can be found in many ophiolite terranes. The world's largest ophiolite, the Semail ophiolite of Oman/United Arab Emirates, has long been known to exhibit a stratigraphy of FAB-like tholeiites overlain by depleted arc tholeiites (e.g., Alabaster et al., 1982), and recent discoveries of boninites in the upper part of the sequence (Ishikawa et al., 2002) confirm the full trend from tholeiite to boninites. Other large, complete ophiolites with complex fore-arctype stratigraphies involving tholeiites and boninites include the Troodos Massif of Cyprus, the Pindos Mountains in Greece, the Bay of Islands ophiolite in Newfoundland (Canada), and numerous others distributed through most of the world's mountain belts (e.g., Pearce et al., 1984; Dilek and Flower, 2003). Many of these stratigraphies are economically significant, with associated volcanogenic massive deposits and/or podiform chromite mineralization.

The presence of boninites is in itself an important tectonic indicator, requiring a combination of shallow melting, high water content, and depleted mantle. Boninites are defined by the International Union of Geological Sciences (IUGS) to have $>52 \mathrm{wt} \%$ silica, $<0.5 \mathrm{wt} \% \mathrm{TiO}_{2}$, and $>8 \mathrm{wt} \% \mathrm{MgO}$ and can usefully be distinguished from basalts on a diagram of Ti8 versus $\mathrm{Si} 8$, where Ti8 and $\mathrm{Si} 8$ refer to the oxide concentrations at $8 \mathrm{wt} \% \mathrm{MgO}$ (Pearce and Robinson, 2010). On this projection (Figure F7), the earliest lavas are basalts (FAB) that plot in the MORB field. Later lavas ( 48-44 $\mathrm{Ma})$ plot as boninites before compositions eventually become basal- 
Figure F6. Interpretation of tectonic evolution of the Bonin Ridge in Ishizuka (2006) based on the concept of Stern and Bloomer (1992). According to this model, subduction initiation is followed by sinking of the slab with slab-parallel subduction and hence normal arc volcanism only beginning later. Later discoveries of fore-arc basalt in the Mariana and Bonin fore arcs (Reagan et al., 2010; Ishizuka et al., 2011) have pushed back to 52-45 Ma the period addressed by this expedition in an attempt to test this model in detail. BRE $=$ Bonin Ridge Escarpment.

Infant arc (52-45 Ma)

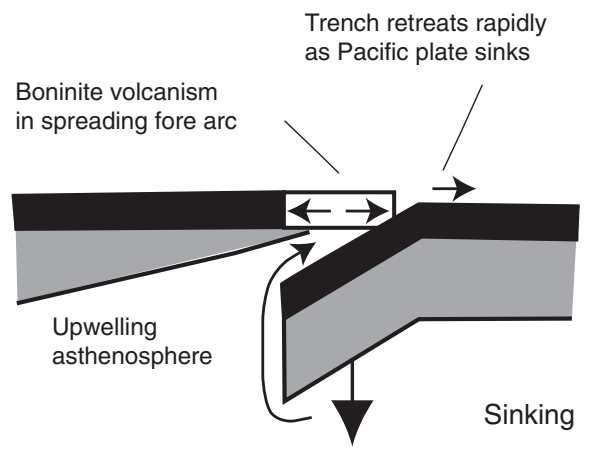

Transitional arc (45-41 Ma)

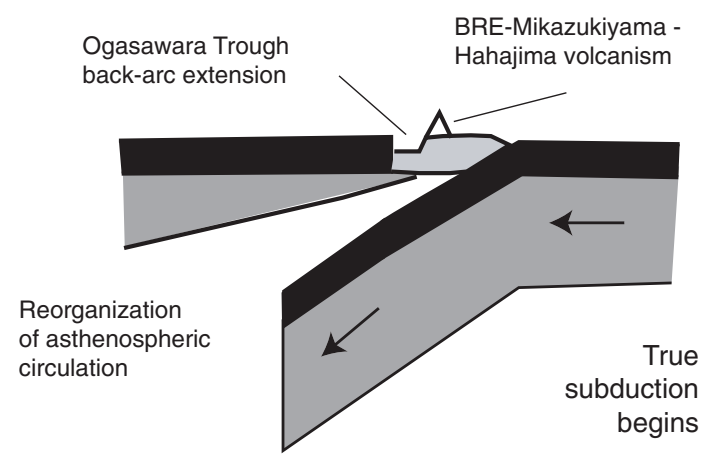

Mature arc (41 Ma to present)

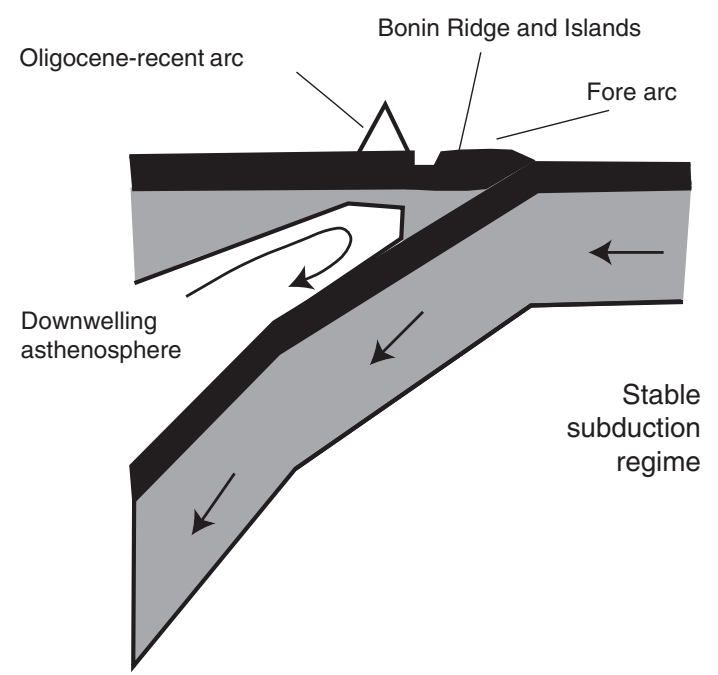

tic again with eruptions at, for example, Hahajima. This appears to be a characteristic of subduction initiation but to properly interpret its tectonic significance we need the full lava stratigraphy to know
Figure F7. Basalt and boninite composition defined in terms of Ti8 and Si8. Yellow field $=$ compositional field of boninite as defined by IUGS. Red line $=$ Pearce and Robinson's (2010) definition of the compositional boundary between basalt and boninite. Basaltic vs. boninitic character is further defined in this figure as a function of the age of the lava following subduction initiation in the Bonin fore arc. FAB erupts first and at the end, but otherwise boninites dominate. Boninites are characteristic of subduction initiation, and the full stratigraphy would enable their tectonic significance to be explained better. Data are from Pearce et al. (1999), Reagan et al. (2010), and Ishizuka et al. (2011). IAB = island arc basalt, $\mathrm{Chi}=$ Chichijima.

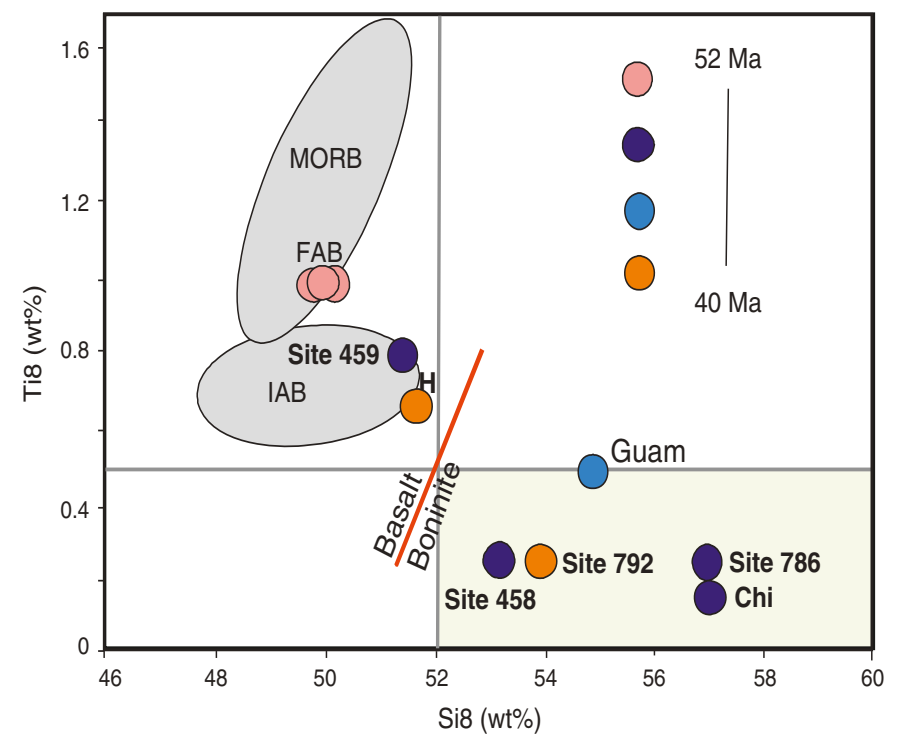

whether the basalt-boninite transition is gradational or episodic or has both magma sources available simultaneously. Drill core would also enhance the opportunity to obtain glass samples that can be analyzed for volatile and fluid-mobile element concentrations.

After a brief period of spreading, lavas began to build atop the newly formed crust and retreat from the trench, at the same time changing composition, perhaps first from FAB to boninite and then from boninite to calc-alkaline and tholeiitic arc magmas. The timing and rate of the migration of the magmatic locus away from the trench remains uncertain, but it is clear that the locus of magmatism reached the location of the first magmatic arc on Guam and the edge of the Ogasawara escarpment within $\sim 8$ million years. This left vast tracts of infant arc crust "stranded" to form the IBM fore arc, which cooled and remained "frozen" in its primitive state. Understanding the formation of fore-arc crust is clearly critical for understanding the formation of subduction zones (and the magmatic responses), growth of arcs, evolution of continental crust, and origins of ophiolites.

\section{Structure and thickness of fore-arc crust}

The most detailed trench-orthogonal published images of IBM fore-arc crustal structure near the Expedition 352 region come from a seismic refraction/reflection study by Kamimura et al. (2002) located some distance north of Sites U1439-U1442. While recognizing that the actual crustal structure for the drill sites might be slightly different than that shown, we infer from this study that the crust beneath the drill sites is $6-8 \mathrm{~km}$ thick-slightly thicker than normal oceanic crust. In detail, the crust beneath this part of the fore arc can be divided into five layers. The first layer $\left(V_{\mathrm{P}}=1.8-2.0\right.$ $\mathrm{km} / \mathrm{s}$ ) is mostly composed of thin sediment; this layer is very variable, and Sites U1439-U1442 were originally chosen to have at least 
$100 \mathrm{~m}$ of sediment in order to facilitate drilling and casing operations of the uppermost part of the holes. The second layer $\left(V_{\mathrm{P}}=\right.$ $2.6-3.3 \mathrm{~km} / \mathrm{s}$ ) is $1-2 \mathrm{~km}$ thick and probably consists of fractured volcanic rocks and dikes; this information contributed to our precruise estimate of $1.25 \pm 0.25 \mathrm{~km}$ as the likely lava thickness that we needed to drill in order to reach the sheeted dikes.

\section{Choice of drill sites}

The Bonin fore arc was chosen because it had the advantage of being in the same region as Chichijima (Bonin Island), the type locality for the key boninite rock type. It is part of a complete ophiolite section that has been sampled by dredging and diving (Ishizuka et al., 2011) and has full site survey data (Kodaira et al., 2010, pers. comm., 2013).

Two important hypotheses to be tested by drilling have been (1) that subduction initiation produces a consistent volcanic stratigraphy of (from oldest to youngest) FAB, transitional lavas, low-calcium boninites, enriched high-magnesium andesite and related rocks, and normal arc volcanic rocks (Reagan et al., 2010) and (2) that this sequence was originally stacked vertically before erosion and therefore represents an in situ analog for sections through many suprasubduction zone (SSZ) ophiolites. Sites U1439-U1442 (Figure F8) were chosen to maximize the likelihood of testing these hypothesis because the sheeted dike/FAB contact was approximately located during Shinkai 6500 diving in 2009 along the inner wall of the Bonin Trench, near a location where the drill could spud into a sediment pond and sample the lower part of the fore-arc volcanic succession.

Figure F9 summarizes the distribution of rocks sampled during three expeditions: YK04-05, the first manned submersible (Shinkai 6500) diving survey of the western escarpment of the Bonin Ridge (Ishizuka et al., 2006); R/V Hakuho-maru KH07-2, which dredged 19 stations along the length of Bonin Ridge; and YK09-06 in the proposed Site U1439-U1442 area (Ishizuka et al., 2011). They show that, in particular,

1. Overall, there is an ophiolite-like sequence in the inner trench wall of lavas, dikes, gabbros, and peridotites;

2. Of the lavas and dikes, MORB-like tholeiites occupy the deepest part of the trench-side slope of the ridge (i.e., the easternmost part of the ridge). These are chemically indistinguishable from FAB as defined by Reagan et al. (2010) from the Mariana fore arc;

3. Boninites crop out to the west and upslope of the FAB/MORB outcrops; and

4. Younger tholeiitic/calc-alkaline basalt to rhyolite crop out on the western Bonin Ridge and are especially well exposed on the western escarpment.

The 2009 diving survey using the Shinkai 6500 examined and better established the igneous fore-arc stratigraphy exposed on the trench-side slope of the Bonin Ridge (YK09-06 cruise: 24 May-10 June 2009; Ishizuka et al., 2011). The northernmost dive area near $28^{\circ} 25^{\prime} \mathrm{N}$ for this survey (Dives 1149, 1150, 1153, and 1154) was located near the drill sites (Figure F8).

The deepest dive (1149) sampled gabbro and basalt/dolerite and appears to have traversed the boundary between the two units. The lower slope traversed during Dive 1149 is composed of fractured gabbro, whereas pillow lavas were observed in the uppermost part of this dive at $\sim 6000 \mathrm{~m}$ water depth. Dives 1153 and 1154 surveyed upslope of Dive 1149 between 6000 and $5200 \mathrm{~m}$ water depth. These two dives found outcrops of gabbro and dolerite, as well as fractured basalt lava cut by dikes. The contact between basalt and dolerite
Figure F8. Expedition 352 sites and locations of Shinkai 6500 dives discussed in the text.

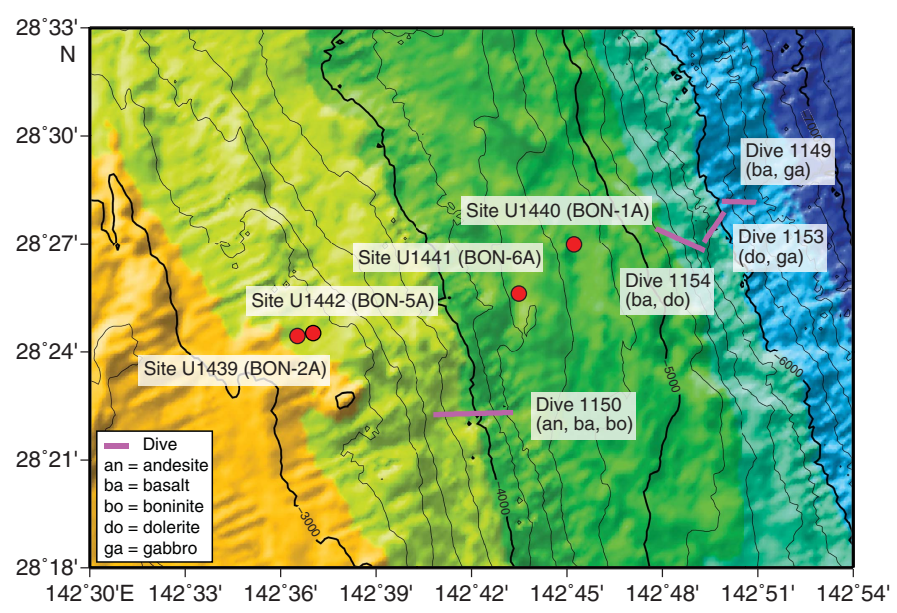

Figure F9. Rock types recovered from dredging and diving expeditions to the Bonin fore arc, showing its ophiolitic structure (after Ishizuka et al., 2011). Stars = Sites U1439-U1442, boxes $=$ areas chosen for more detailed site survey dives.

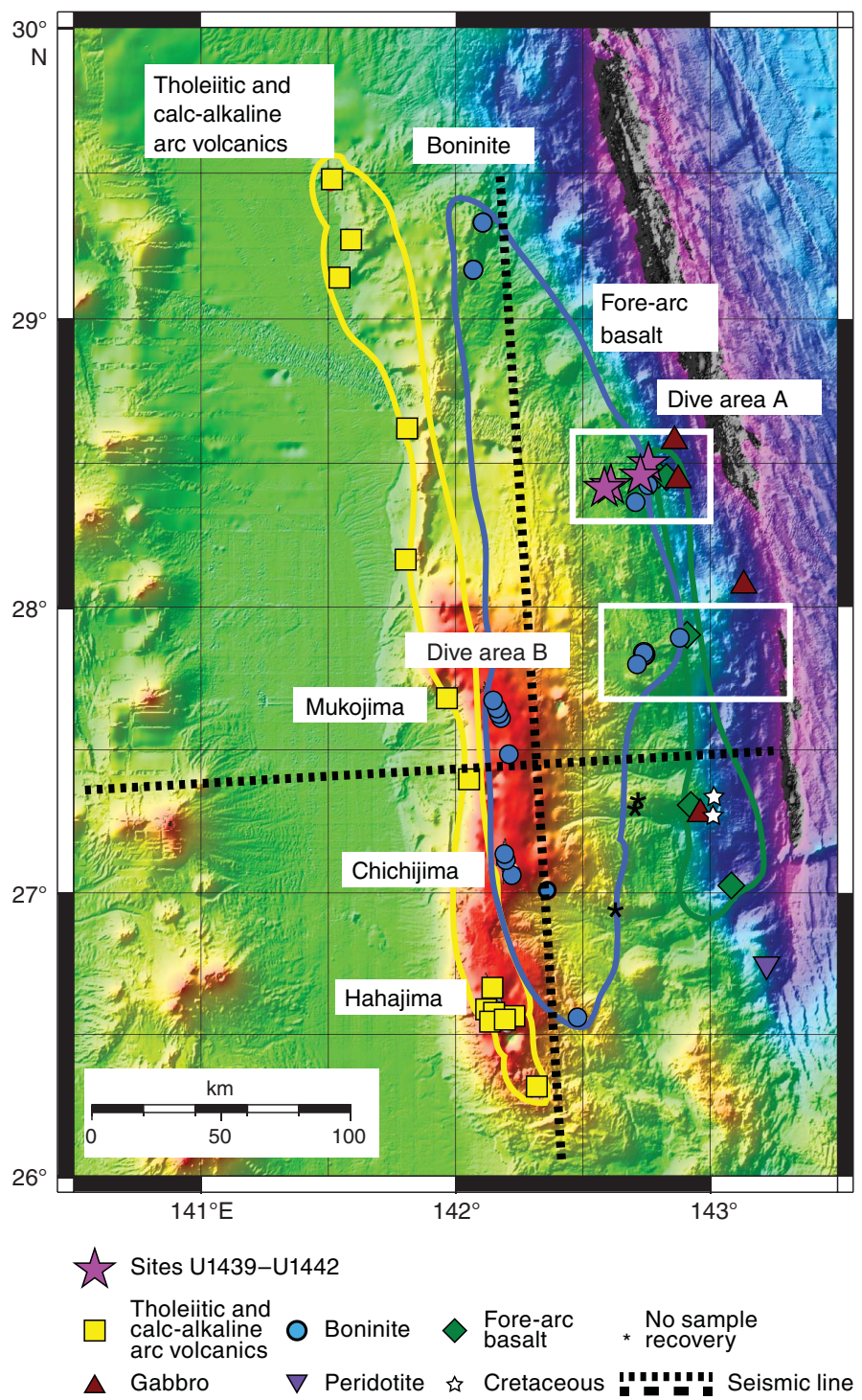


Figure F10. Schematic cross-section (not to scale) for the Bonin fore-arc drill site area.

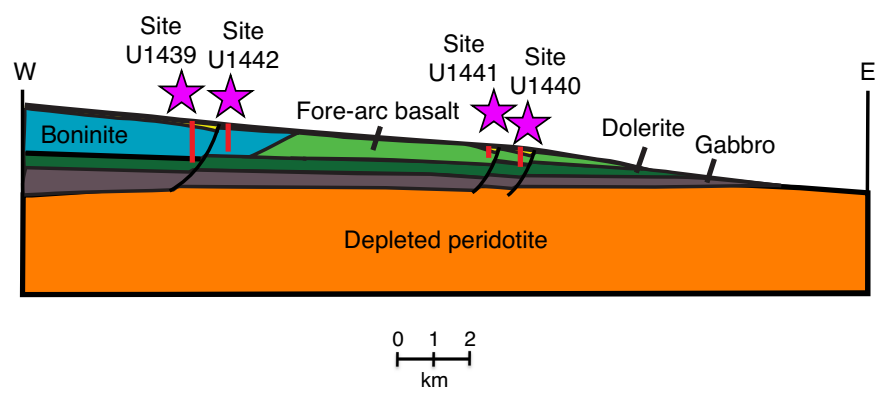

was thought to be $\sim 5400 \mathrm{~m}$ based on these results, and Site U1440 was chosen to drill through this contact (Figure F10). The shallowest dive $(1150 ; 4600$ to $3700 \mathrm{~m})$ recovered volcanic breccia and conglomerate with boninite. Thus, the boundary between boninite and basalt was estimated to lie at $\sim 4000 \mathrm{~m}$ water depth. Site U1439 was chosen to drill through the transition zone from boninite to basalt. The resulting drilling has shown that this boundary might be geographically limited and lie to the east.

\section{Scientific objectives}

\section{Obtain a high-fidelity record of magmatic evolution during sub- duction initiation by coring volcanic rocks down to underlying in- trusive rocks, including radiometric and biostratigraphic ages.}

Recent advances in studying the IBM fore arc document important vertical compositional variations within the volcanic sections. We know that the IBM fore arc exposes rocks that formed after this subduction zone began at $~ 52$ Ma (Stern and Bloomer, 1992; Ishizuka et al., 2011). Reagan et al. (2010) documented that the volcanic succession exposed in the inner trench wall of the southernmost Mariana fore arc comprises a volcanic succession that changes from MORB-like tholeiites at the base (FAB) through increasingly arc-like basalts to boninites near the top. They inferred that the 450-700 m sections cored at Sites 458 and 459 in the Mariana fore arc sampled the transition between the FAB and boninite successions. Similar successions are common in ophiolites, many of which are increasingly recognized as fossil fore arcs (Stern et al., 2012; see below). The significance of this simple succession has not hitherto been appreciated because of a lack of direct information on fore-arc volcanic stratigraphy, mainly because this was not a priority for dredging and diving. The results of Reagan et al. (2010) provide the first reconstruction of this stratigraphy, and this dredging and diving in the Bonin fore arc was undertaken to see whether a similar magmatic stratigraphy was present there. In the area, the results of Ishizuka et al. (2011) support the conclusions of Reagan et al. (2010). Drilling and coring of the volcanic succession at or near Sites U1439-U1442 will provide a crucial test of this hypothesis by providing a more continuous section. It is also important to further constrain the rates at which the fore-arc magmatic succession was emplaced. Evidence so far available indicates that this sequence takes 7-8 million years to form during subduction initiation, after which magmatic activity retreats $\sim 200 \mathrm{~km}$ to the ultimate position of the arc magmatic front. Recovered cores should provide more material for $\mathrm{U}-\mathrm{Pb}$ zircon, ${ }^{40} \mathrm{Ar} /{ }^{39} \mathrm{Ar}$, and biostratigraphic age determinations.

\section{Use the results of Objective 1 to test the hypothesis that fore-arc basalt lies beneath boninites and to understand chemical gradi- ents within these units and across their transitions.}

We expect to find a thick section of FAB at the base of the Bonin fore-arc volcanic succession and a thinner sequence of arc-like and boninitic lavas at the top. To understand the significance of these vertical variations, we need to know how the transition from one magma type to the next takes place: is it a step-function, or is there a slow transition from one magma type to the next? If it is a transition, we need to know whether it is continuous, gradual, and progressive or whether it is accomplished by alternations of one magma type with another. Within the main FAB sequence, we need to know whether there is any evidence that the subduction component increases with stratigraphic height and thus time. A key related question is whether the boninites vary in any systematic way upsection, for example from high-calcium boninite at the base to low-calcium boninite near the top. The nature of these transitions and variations provide important constraints for how mantle and subducted sources and processes changed with time as subduction initiation progressed.

\section{Use drilling results to understand how mantle melting processes evolve during and after subduction initiation.}

Assuming that we are able to accomplish Objectives 1 and 2, we will use the results to better understand how the mantle responds to subduction initiation. For example, a thick basal FAB succession indicates that adiabatic decompression is the most important process at the very beginning of subduction initiation in the IBM system, and an upper section of boninites indicates that flux melting was important just before the transition into normal arc magmatism. Whatever information is obtained from the cores will be used to construct geodynamic and petrologic models of this transition.

\section{Test the hypothesis that the fore-arc lithosphere created during subduction initiation is the birthplace of suprasubduction zone ophiolites.}

Much has rightly been made of the highly successful efforts of IODP and its precursors in establishing the architecture and crustal accretion processes associated with mid-ocean ridges of varying spreading rates and linking these to ophiolites. As discussed earlier, however, it now appears that most ophiolites form when subduction begins, and that they are preserved as fore-arc crust until they are obducted. One testable hypothesis is that ophiolites that formed during subduction initiation can be recognized by a volcanic stratigraphy that varies from MORB-like at the base to arc-like or boninitic near the top, similar to the sequence that we expected to recover from the IBM fore arc. Most ophiolites are not well enough preserved or studied to infer volcanic chemostratigraphies, but some are and have volcanic stratigraphies that are similar to those of the IBM fore arc (e.g., Mesozoic ophiolites such as Pindos, Mirdita, Semail, and Troodos and Ordovician ophiolites of the northeast Appalachians and Norwegian Caledonides). Results from Bonin fore-arc drilling will allow us to prepare a more detailed volcanic chemostratigraphy expected for subduction initiation, which will in turn allow more detailed comparisons with these ophiolites. 


\section{Principal results Site U1439 summary}

\section{Operations}

After a $457 \mathrm{nmi}$ transit from Yokohama, Japan, the vessel arrived at Site U1439 (proposed Site BON-2A; Figure F8). The vessel stabilized over the site at $0324 \mathrm{~h}$ (all times reported are ship local time, UTC +9 h) on 6 August 2014. Because of the short initial period planned at this site, no seafloor-positioning beacon was deployed, and GPS was used for positioning the ship. A seafloor beacon was subsequently deployed once the vessel returned to Site U1439 on 26 August.

Site U1439 consists of three holes. Hole U1439A was cored using the advanced piston corer (APC)/extended core barrel (XCB) system to 199.4 meters below seafloor (mbsf) (Table T1). Nonmagnetic core barrels were used for Cores $352-\mathrm{U} 1439 \mathrm{~A}-1 \mathrm{H}$ to $10 \mathrm{H}$. Core orientation was performed using the FlexIT tool on Cores $2 \mathrm{H}$ through $9 \mathrm{H}$. Temperature measurements were taken with the advanced piston corer temperature tool (APCT-3) on Cores $4 \mathrm{H}, 6 \mathrm{H}$, $8 \mathrm{H}$, and $10 \mathrm{H}$. Basement was tagged with the XCB system for the purpose of identifying where in the volcanic stratigraphy this section belongs. Ten APC cores were taken over a $92.3 \mathrm{~m}$ interval and recovered $84.3 \mathrm{~m}(91 \%)$. Thirteen $\mathrm{XCB}$ cores were taken over a $107.1 \mathrm{~m}$ interval and recovered $86.4 \mathrm{~m}(81 \%)$. Overall recovery in
Hole U1439A was $86 \%$. The total time spent on Hole U1439A was $59.75 \mathrm{~h}$.

The vessel was offset 20 m east on 8 August, and Hole U1439B was drilled without coring to $42.2 \mathrm{mbsf}$ for a jet-in test in advance of deploying casing beneath a reentry cone in Hole U1439C. After the completion of the jet-in test, the drill string was raised to $100 \mathrm{~m}$ above the seafloor, and at $2030 \mathrm{~h}$ on 8 August the vessel moved to Site U1440 using the dynamic positioning system.

After completion of operations at Site U1440, the vessel moved back to Site U1439 on 26 August. A reentry system was prepared, and $178.5 \mathrm{~m}$ of 10.75 inch casing was assembled and landed in the reentry cone in the moonpool. A drilling bottom-hole assembly (BHA), including a mud motor, underreamer, and bit, was picked up and installed. The casing with the reentry system attached was lowered to the bottom, drilled into the seafloor, and released on $27 \mathrm{Au}-$ gust. Hole U1439C was cored with the rotary core barrel (RCB) system to $544.3 \mathrm{mbsf}$ (Table T1). Coring was terminated on 8 September as a result of poor hole conditions. A total of 45 rotary cores were taken over a $362.3 \mathrm{~m}$ interval and recovered $107.8 \mathrm{~m}$ (30\%). An additional $1.5 \mathrm{~m}$ of material was recovered during hole cleaning operations. The hole was logged to $\sim 400 \mathrm{mbsf}$ with the triple combination-Magnetic Susceptibility Sonde (triple combo-MSS) and Formation MicroScanner (FMS)-sonic tool strings. The total time spent in Hole U1439C was 382.75 h. The total time spent at Site

Table T1. Operations summary, Expedition 352. APC = advanced piston corer, XCB = extended core barrel, RCB = rotary core barrel. $-=$ no data. Download table in .csv format.

\begin{tabular}{|c|c|c|c|c|c|c|c|c|}
\hline Hole & Latitude & Longitude & $\begin{array}{c}\text { Water } \\
\text { depth }(\mathrm{m})\end{array}$ & $\begin{array}{c}\text { Total } \\
\text { penetration }(\mathrm{m})\end{array}$ & $\begin{array}{c}\text { Drilled } \\
\text { interval }(\mathrm{m})\end{array}$ & $\begin{array}{c}\text { Cored } \\
\text { interval }(\mathrm{m})\end{array}$ & $\begin{array}{l}\text { Core } \\
\text { recovered }(\mathrm{m})\end{array}$ & $\begin{array}{c}\text { Recovery } \\
(\%)\end{array}$ \\
\hline U1439A & $28^{\circ} 24.4487^{\prime} \mathrm{N}$ & $142^{\circ} 36.5120^{\prime} \mathrm{E}$ & 3128.1 & 199.4 & - & 199.4 & 170.7 & 86 \\
\hline U1439B & $28^{\circ} 24.4478^{\prime} \mathrm{N}$ & $142^{\circ} 36.5244^{\prime} \mathrm{E}$ & 3128.2 & 42.2 & 42.2 & - & - & - \\
\hline \multirow[t]{2}{*}{ U1439C } & $28^{\circ} 24.4491^{\prime} \mathrm{N}$ & $142^{\circ} 36.5368^{\prime} \mathrm{E}$ & 3129.2 & 544.3 & 182.0 & 362.3 & 107.8 & 30 \\
\hline & & Site U1439 totals: & & 785.9 & 224.2 & 561.7 & 278.5 & 50 \\
\hline U1440A & $28^{\circ} 26.9890^{\prime} \mathrm{N}$ & $142^{\circ} 45.2243^{\prime} \mathrm{E}$ & 4775.2 & 106.1 & - & 106.1 & 96.6 & 91 \\
\hline \multirow{2}{*}{ U1440B } & $28^{\circ} 26.9976^{\prime} \mathrm{N}$ & $142^{\circ} 45.2244^{\prime} \mathrm{E}$ & 4775.2 & 383.6 & 102.3 & 281.3 & 34.7 & 12 \\
\hline & & Site U1440 totals: & & 489.7 & 102.3 & 387.4 & 131.3 & 34 \\
\hline \multirow[t]{2}{*}{ U1441A } & $28^{\circ} 25.6379^{\prime} \mathrm{N}$ & $142^{\circ} 43.5390^{\prime} \mathrm{E}$ & 4446.9 & 205.7 & - & 205.7 & 50.7 & 25 \\
\hline & & Site U1441 totals: & & 205.7 & - & 205.7 & 50.7 & 25 \\
\hline \multirow[t]{3}{*}{ U1442A } & $28^{\circ} 24.5784^{\prime} \mathrm{N}$ & $142^{\circ} 37.3368^{\prime} \mathrm{E}$ & 3162.0 & 529.8 & - & 529.8 & 100.7 & 19 \\
\hline & & Site U1442 totals: & & 529.8 & - & 529.8 & 100.7 & 19 \\
\hline & & Expedition 352 totals: & - & 2011.1 & 326.5 & 1684.6 & 561.2 & 33 \\
\hline
\end{tabular}

\begin{tabular}{|c|c|c|c|c|c|c|c|c|c|c|}
\hline Hole & $\begin{array}{c}\text { Total } \\
\text { cores }(N)\end{array}$ & $\begin{array}{c}\text { APC } \\
\text { cores }(N)\end{array}$ & $\begin{array}{c}\mathrm{XCB} \\
\text { cores }(N)\end{array}$ & $\begin{array}{c}\text { RCB } \\
\text { cores }(N)\end{array}$ & $\begin{array}{c}\text { Ghost } \\
\text { cores }(N)\end{array}$ & $\begin{array}{l}\text { Start date } \\
(2014)\end{array}$ & $\begin{array}{l}\text { Start time } \\
\text { UTC (h) }\end{array}$ & $\begin{array}{l}\text { End date } \\
\text { (2014) }\end{array}$ & $\begin{array}{l}\text { End time } \\
\text { UTC (h) }\end{array}$ & $\begin{array}{c}\text { Time on } \\
\text { hole (days) }\end{array}$ \\
\hline U1439A & 23 & 10 & 13 & 0 & 0 & 5 Aug & 1824 & 8 Aug & 0620 & 2.5 \\
\hline U1439B & - & - & - & - & - & 8 Aug & 0620 & 8 Aug & 1135 & 0.2 \\
\hline \multirow[t]{2}{*}{ U1439C } & 42 & 0 & 0 & 42 & 3 & \multirow[t]{2}{*}{26 Aug } & \multirow[t]{2}{*}{0310} & \multirow[t]{2}{*}{$11 \mathrm{Sep}$} & \multirow[t]{2}{*}{0205} & 16.0 \\
\hline & & 10 & 13 & 42 & 3 & & & & & 18.7 \\
\hline U1440A & 14 & 12 & 2 & 0 & 0 & 8 Aug & 2130 & 10 Aug & 2235 & 2.1 \\
\hline \multirow[t]{2}{*}{ U1440B } & 36 & 0 & 0 & 36 & 1 & \multirow[t]{2}{*}{10 Aug } & \multirow[t]{2}{*}{2235} & \multirow[t]{2}{*}{26 Aug } & \multirow[t]{2}{*}{0310} & 15.2 \\
\hline & 50 & 12 & 2 & 36 & 1 & & & & & 17.3 \\
\hline \multirow[t]{2}{*}{ U1441A } & 22 & 0 & 0 & 22 & 0 & \multirow[t]{2}{*}{11 Sep } & \multirow[t]{2}{*}{0205} & \multirow[t]{2}{*}{14 Sep } & \multirow[t]{2}{*}{0550} & 3.2 \\
\hline & 22 & 0 & 0 & 22 & 0 & & & & & 3.2 \\
\hline \multirow[t]{3}{*}{ U1442A } & 57 & 0 & 0 & 57 & 0 & \multirow[t]{3}{*}{14 Sep } & \multirow[t]{3}{*}{0550} & \multirow[t]{3}{*}{24 Sep } & \multirow[t]{3}{*}{0130} & 9.8 \\
\hline & 57 & 0 & 0 & 57 & 0 & & & & & 9.8 \\
\hline & 194 & 22 & 15 & 157 & 4 & & & & & 49.0 \\
\hline
\end{tabular}


U1439 was 447.75 h, or 18.66 days. The vessel moved to Site U1441 on 11 September.

\section{Sedimentology}

Sediment and sedimentary rocks were recovered from the seafloor to 176.47 mbsf in Hole U1439A, beneath which a thin interval of basic volcanic and volcaniclastic rocks was recovered within the igneous basement. The sediment represents the late Eocene-recent deep-sea sedimentary cover of the Izu-Bonin fore-arc basement. The underlying volcanogenic rocks are interpreted as the fore-arc basement. The sedimentary succession is divided into five lithologically distinct units (Figure F11). Lithologic Units I and II are each further divided into two subunits. The main criteria for the recognition of the lithologic units and subunits are a combination of primary lithology, grain size, color, and diagenesis. Within the overall succession, 44 ash or tuff layers were observed.

Figure F11. Lithostratigraphic sediment units and ages based on biostratigraphy.

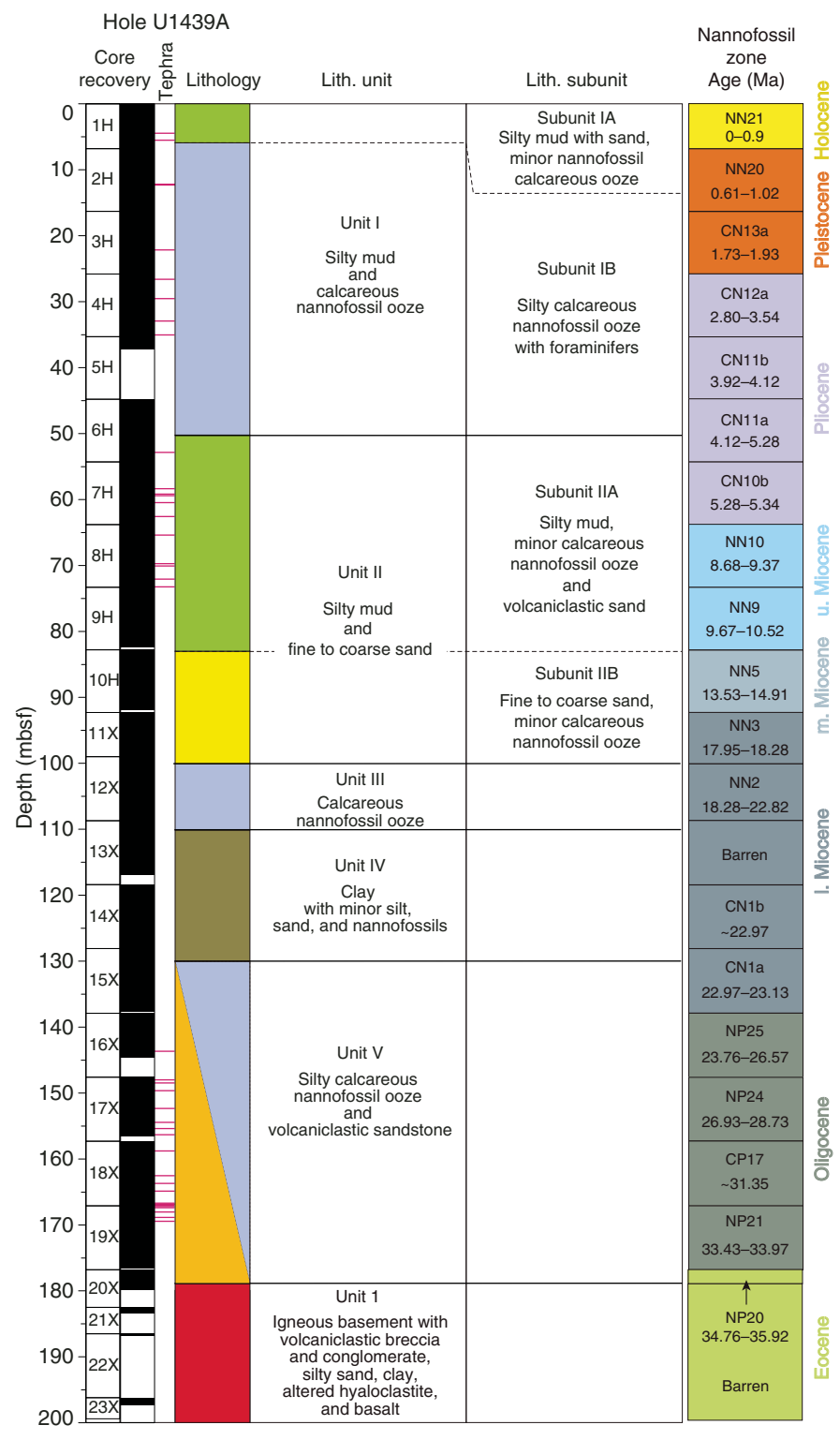

- Unit I (0-50.43 mbsf) is recognized mainly on the basis of a relatively high abundance of calcareous nannofossils compared to the sediment beneath. Unit I is divided into an upper, relatively nannofossil-poor subunit (0-5.54 mbsf) and a lower, relatively nannofossil-rich subunit (5.54-50.43 mbsf).

- Unit II (50.43-100.50 mbsf) is recognized on the basis of a downward change to silty mud and fine to coarse sand, in which the upper subunit (50.43-82.80) is relatively fine grained and the lower subunit (82.80-100.50 mbsf) relatively coarse grained.

- Unit III (100.50-110.93 mbsf) is easily recognizable because of a predominance of pale nannofossil ooze.

- Unit IV (110.93-129.76 mbsf) is marked by a distinct downward change to more clastic sediment dominated by clay, with minor silt, sand, and nannofossil-bearing sediment.

- Unit V (129.76-178.50 mbsf) is characterized by a diverse mixture of fine- to coarse-grained clastic sediment interbedded with fine-grained, nannofossil-rich sediment and sedimentary rock. The base of Unit $\mathrm{V}$ is defined as a thin $(<3 \mathrm{~cm})$ layer of dark gray to black, weakly consolidated manganese oxide-rich sediment.

\section{Biostratigraphy}

Calcareous nannofossils were present in 19 of 22 Hole U1439A core catcher samples and Sample 352-U1439A-20X-2, 0-2 cm. Preservation of calcareous nannofossils is variable, ranging from "good" in the most recent samples to "poor" in certain taxa and intervals. The oldest samples in the hole exhibit more diagenesis than younger samples. Reworking may be common throughout the section, making initial age constraints somewhat difficult. Close examination reveals somewhat continuous recovery from the Upper Pleistocene to the upper Eocene with a few gaps, especially in Miocene-aged sediment (Figure F11). The youngest age obtained was Late Pleistocene (Subzone CN14b; 0.24-.424 Ma), whereas the oldest age was late Eocene/early Oligocene (Zones NP19/20 or NP21; 34.76-35.92 Ma).

\section{Fluid geochemistry}

Twenty-one samples were collected in Hole U1439A for headspace hydrocarbon gas analysis as part of the standard shipboard safety monitoring procedure; one sample per core was collected from Cores 352-U1439A-1H through 23X, except for Cores 21X and $22 \mathrm{X}$, in which no sediment was recovered. Thirteen wholeround samples were collected for interstitial water analyses in Hole U1439A, one sample per core from Cores $1 \mathrm{H}$ through $10 \mathrm{H}$ and one sample every three cores from Cores $13 \mathrm{X}$ through 19X. No headspace gas or interstitial water samples were collected from the basement rocks in Hole U1439C. All interstitial water samples were analyzed for salinity, alkalinity, $\mathrm{pH}, \mathrm{Cl}^{-}, \mathrm{Br}^{-}, \mathrm{SO}_{4}{ }^{2-}, \mathrm{Na}^{+}, \mathrm{K}^{+}, \mathrm{Ca}^{2+}$, $\mathrm{Mg}^{2+}$, and $\mathrm{PO}_{4}{ }^{3-}$.

Methane concentrations range from 2.49 to $12.44 \mathrm{ppmv}$ in Hole U1439A, with the highest methane concentration measured in Core $1 \mathrm{H}$ at 5.9 mbsf. This high value is attributed to decomposition of organic matter in the uppermost layers of the sedimentary column. No ethane or propane was detected in Hole U1439A samples. The major result of the interstitial water analyses from Hole U1439A is a broad correlation with the described lithologic units, with the exception of $\mathrm{Mg}^{2+}$ and $\mathrm{Ca}^{2+}$. The distribution of these elements in the sedimentary column is invariant of lithology and shows a downhole increase in $\mathrm{Ca}^{2+}$ to $40.5 \mathrm{mM}$ and a decrease in $\mathrm{Mg}^{2+}$ to $39.2 \mathrm{mM}$. These variations can probably be attributed to metasomatism by interaction with fluids released from the basaltic basement. 


\section{Petrology}

Igneous rocks were recovered in Holes U1439A and U1439C. Hole U1439A tagged basement during XCB coring (Cores 352U1439A-20X through 23X; 3.7 m recovery), whereas Hole U1439C penetrated $362.3 \mathrm{~m}$ of igneous basement (Cores 352-U1439C-2R through 45R; $108.5 \mathrm{~m}$ recovery). The uppermost part of the section comprises heterolithic breccia, which represents seafloor colluvium. The lowermost part of the section is composed of mafic dikes or sills. The volcanic rocks in between are dominated by pillow lava with intercalations of massive sheet flows, igneous breccias especially hyaloclastites, and subaqueous pyroclastic flow deposits. This site is notable for the variety of boninites cored and for the intercalation of more and less differentiated boninites at several levels throughout the section. In one unit, these magmas appear to have erupted simultaneously, forming complex magma mingling tex- tures. Phenocrysts are common in the basement boninitic rocks throughout Holes U1439A and U1439C. However, the variations in phase assemblages and abundances are not always diagnostic. As a result, chemical distinctions based on portable X-ray fluorescence (pXRF) spectrometry were also used to assess changes in rock composition and to track the occurrence of different magma series.

Ten igneous units were identified in the basement at Site U1439 (Figure F12). Unit boundaries represent an abrupt change in chemical characteristics, phenocrysts, and groundmass assemblages. Subunits typically represent changes in the eruptive nature of a unit (e.g., from hyaloclastite to pillow lava or massive lava), although minor changes in chemical composition occur at some subunit boundaries. Unit 10 is doleritic and was interpreted to represent sheeted shallow dikes or sills.

Figure F12. Lithostratigraphic igneous units. Red hatched bars adjacent to lithology column represent fault zones. HSB = high-silica boninite, LSB $=$ low-silica boninite.

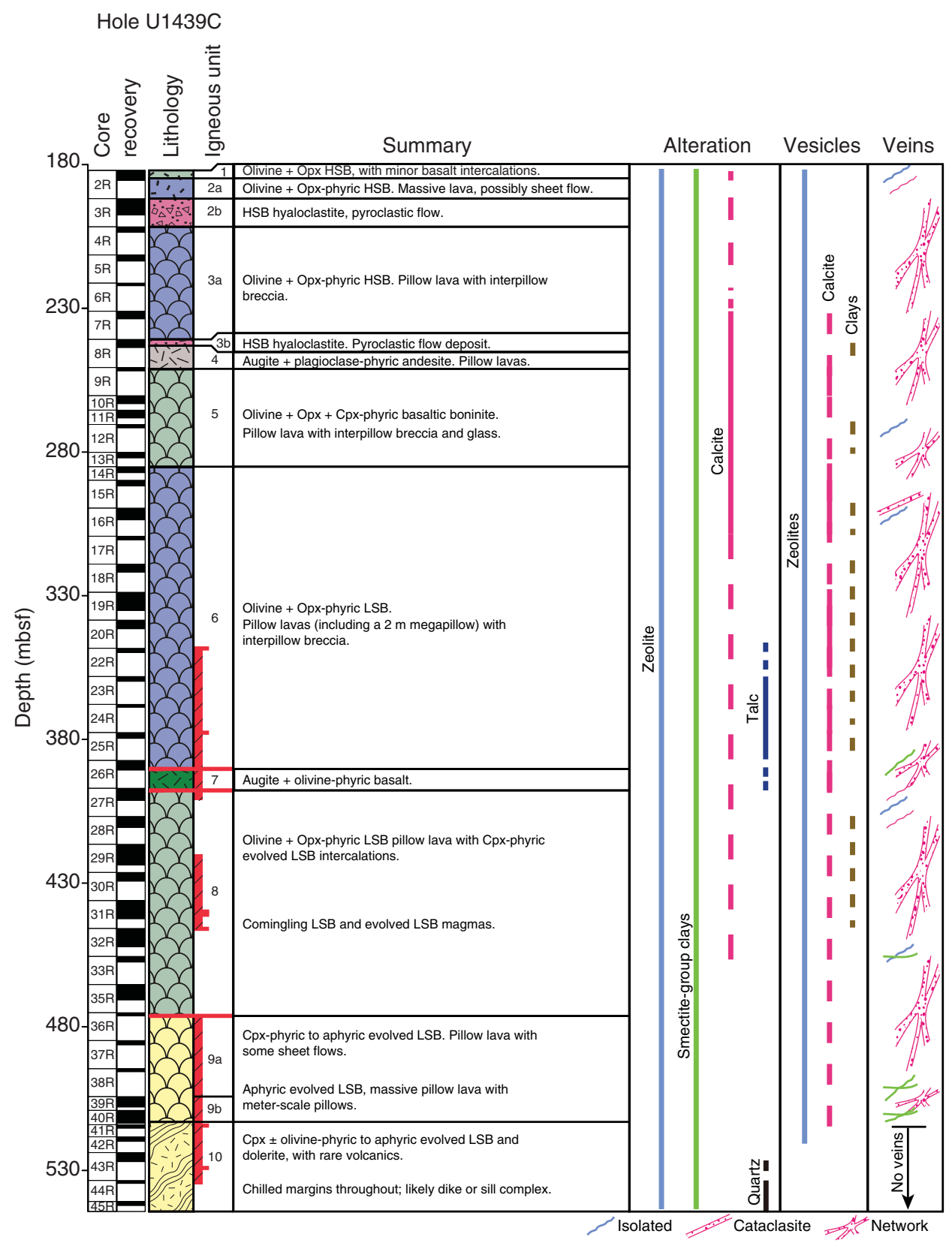


Fresh igneous rocks at Site U1439 are dominantly boninites characterized by phenocrysts of olivine and orthopyroxene and are typically set in a groundmass of pale glass and acicular to tabular pyroxene prisms. Acicular plagioclase is commonly present in the groundmasses of differentiated boninites. Phenocryst and groundmass assemblages document a range in boninite compositions:

1. Orthopyroxene $>$ olivine phenocrysts with an orthopyroxenedominated groundmass (Units 1-4),

2. Olivine + augite \pm orthopyroxene phenocrysts with an augite \pm plagioclase-bearing groundmass (Unit 5 ), and

3 . Olivine $>$ orthopyroxene \pm augite phenocrysts with augite \pm orthopyroxene \pm plagioclase in the groundmass (Units 6-9).

Based on using Niton handheld pXRF analyses, these units are also distinguished by their $\mathrm{Ti} / \mathrm{Zr}$ ratios (see Preliminary scientific assessment): Unit 1 has very low $\mathrm{Ti} / \mathrm{Zr}(<60)$, Unit 2 has significantly higher $\mathrm{Ti} / \mathrm{Zr}(90-120)$, and Unit 3 has intermediate $\mathrm{Ti} / \mathrm{Zr}$ (65-90).

Boninites in the first group are canonical boninites, to which we assigned the name "high-silica boninite," whereas those in the second and third groups have lower silica concentrations and were assigned a shipboard classification of "basaltic boninite" and "lowsilica boninite," respectively (see discussion of nomenclature in Preliminary scientific assessment). The basaltic boninites in Hole U1439C are notable for their high magnetic susceptibilities. All boninites are notable for their low $\mathrm{TiO}_{2}$ contents and $\mathrm{Ti} / \mathrm{Zr}$ compared with those of the fore-arc basalts of Site U1440.

Alteration in Hole U1439C basement units is highly variable. Fresh boninite glass is relatively common, but most samples have calcite, zeolite, and/or smectite clays partially or totally replacing groundmass, olivine and more rarely, orthopyroxene phenocrysts. Palagonite, clays, and more rarely, zeolites replace glass. Calcite and zeolite-filled veins and vesicles are common throughout the core, rarely associated with pyrite. Quartz is a rare component in some veins. The alteration generally becomes more intense with depth. Talc is present from Core 350-U1439C-22R to 26R. In fresh glass from Cores 28R to 33R, biogenic microtubes are common. Veins, principally of calcite, zeolite, and smectite, are abundant in Hole U1439C downhole to the boundary between boninite pillow lavas and dolerites.

\section{Rock geochemistry}

Whole-rock chemical analyses were performed on 48 igneous rocks and 22 sediment samples representative of the different lithologic units recovered from Site U1439. The 22 sediment samples were collected in Hole U1439A (1 per core) and analyzed for major and trace element concentrations and volatile contents. Hole U1439A sediments show a broad range of compositions, mainly marking the downhole changes in lithology from the carbonate-rich calcareous ooze $(\mathrm{CaO}>50 \mathrm{wt} \%$, Sr up to $2000 \mathrm{ppm}$, total $\mathrm{C}$ up to $11 \mathrm{wt} \%$, and $\mathrm{Zr}$ of $\sim 30-40 \mathrm{ppm}$ ) to the clay- and volcaniclastic-rich silty muds ( $\mathrm{CaO}<2 \mathrm{wt} \%$, Sr up to $200 \mathrm{ppm}$, and $\mathrm{Zr}$ up to $150 \mathrm{ppm})$. The downhole transition to igneous basement is marked by a thin, muddy, manganese-rich layer $(\mathrm{MnO}=2-5 \mathrm{wt} \%)$ and enrichments in $\mathrm{Cu}(>500 \mathrm{ppm}), \mathrm{V}(>200 \mathrm{ppm})$, and $\mathrm{Zr}(>150 \mathrm{ppm})$.

At the bottom of Hole U1439A, one orthopyroxene-phyric volcanic rock and one volcanic glass were sampled. In addition, 46 igneous rocks were selected by the Shipboard Science Party as representative of the different lithologies recovered from Hole U1439C. The rocks were grouped as olivine-pyroxene-phyric or plagioclase-bearing volcanic rocks. The 48 igneous rocks were ana- lyzed for major and trace element concentrations by inductively coupled plasma-atomic emission spectroscopy (ICP-AES) and for $\mathrm{CO}_{2}$ and $\mathrm{H}_{2} \mathrm{O}$ contents by gas chromatography for samples with loss on ignition (LOI) > $2 \mathrm{wt} \%$. An aliquot of the powder used for ICPAES analyses was subsequently used for XRF analyses, which were carried out with the pXRF. In addition, pXRF "chemostratigraphic" analyses were conducted on 350 archive-half pieces from Hole U1439C cores. The results of these chemical analyses, in conjunction with observations on core material and thin sections carried out by the petrology team, contributed to the lithologic division of the lavas into different units.

Site U1439 igneous rocks range from slightly to highly altered with LOI values from 2.5 to $16.2 \mathrm{wt} \%$. LOI values primarily vary with $\mathrm{H}_{2} \mathrm{O}$ contents $(0.5-8.8 \mathrm{wt} \%)$ and, thus, the amount and type of secondary hydrous minerals. However, several samples from the upper Units 1-8 also show high $\mathrm{CO}_{2}$ values (up to $6.4 \mathrm{wt} \%$ ) together with higher $\mathrm{Ca}$ content, the result mostly of late carbonate addition. This shows that the primary compositions of several samples were modified significantly by alteration. For this reason, the alteration of igneous rocks of Hole U1439C was considered during interpretation of their primary geochemical signature.

Igneous samples recovered from Hole U1439C are boninites with $\mathrm{SiO}_{2}$ concentrations ranging from 50.5 to $60.2 \mathrm{wt} \%$ at total alkali contents of $1.60-4.70 \mathrm{wt} \%$. Olivine-pyroxene-bearing igneous rocks are characterized by high $\mathrm{Cr}$ concentrations (221-1562 ppm), high $\mathrm{Mg} \#$ (cationic $\mathrm{Mg} /[\mathrm{Mg}+\mathrm{Fe}]$, with all $\mathrm{Fe}$ as $\mathrm{Fe}^{2+}$ ) of $64-80$ and $\mathrm{CaO} / \mathrm{Al}_{2} \mathrm{O}_{3}$ ratios of $0.49-0.93$. The lowermost lavas and dolerites (Units 9 and 10) have lower $\mathrm{Cr}$ concentrations (51-750 ppm) and Mg\# (59-76) than overlying units.

A characteristic feature of Site U1439 samples is the progressive decrease in $\mathrm{TiO}_{2}$ concentrations that characterize the transition from the lower Si igneous rocks sampled deep in Hole U1439C to the shallower, higher Si boninite samples. Another characteristic feature is the enrichments in highly incompatible and mobile elements (e.g., Ba) in igneous rocks sampled at Site U1439 compared to those from Site U1440. These enrichments are not correlated with indices of alteration and appear to be of magmatic origin.

\section{Structural geology}

Structures observed in Site U1439 cores originated from drilling-induced, sedimentary, igneous, and tectonic processes. Drilling-induced deformation in the sediment, including draggingdown, rotational shear, and postretrieval core dilation, prevented observation of sedimentary structures between $\sim 92$ and 155 mbsf. Sedimentary structures, such as bedding planes, stylolites, dewatering structures, and cross-bedding, point to an overall nearly horizontal bedding attitude. Igneous structures, although rarely observed, consist of local magmatic foliation marked by alignment of primary grains and a few centimeter-long enclaves in zones of magmatic mingling.

Tectonic structures, present mostly in igneous rocks, comprise tension fractures (veins), shear fractures, breccias, cataclasites, and fault zones. Veins are generally filled with (Mg-) calcite, zeolite, and clay. These veins typically dip steeply and do not correlate with the presence of faults. Vein thickness varies with depth and decreases from 350 to 500 mbsf. Three major fault zones occur at 348-401, 420-446, and 475-535 mbsf. The dominant sense of slip determined on slickensides is normal. Calcite microstructures in the deepest intervals include Type I and II twins, as well as subgrain boundaries, which suggests a relatively high differential stress. 


\section{Physical properties}

Many of the physical property measurements display variability at similar depths, suggesting a few major boundaries. There is a distinct increase in natural gamma ray (NGR) values at 100-130 mbsf in lithologic Units III-IV. At 135-180 mbsf in Unit V, magnetic susceptibility and $P$-wave velocity increase. The reflectance parameters $\mathrm{L}^{*}, \mathrm{a}^{*}$, and $\mathrm{b}^{*}$ decrease with depth from 0 to $130 \mathrm{mbsf}$ in Units I-IV and display an abrupt increase in values at 128-130 mbsf at the boundary between Units IV and V. Bulk, dry, and grain densities show no systematic variation with depth. Porosity increases with depth from 0 to 130 mbsf in Units I-IV and decreases in Unit V.

Magnetic susceptibility distinctly increases and density distinctly decreases at 478-540 mbsf in igneous Units 9-10. NGR values decrease with depth from 180 to 390 mbsf in Units 1-6 and are low from 390 to 540 mbsf in Units 8-10, with some peaks correlated to magnetic susceptibility peaks. At $200-240$ mbsf in Subunit 3a, density and $P$-wave velocity increase and porosity decreases. The reflectance parameters $\mathrm{a}^{*}$ and $\mathrm{b}^{*}$ have a small peak at $330 \mathrm{mbsf}$ in Unit 3.

\section{Paleomagnetism}

Sediment cored in Hole U1439A is relatively strongly magnetic and has low coercivities, so it acquired a strong drill string overprint. This overprint was easily removed by alternating field demagnetization, revealing a Pliocene-Pleistocene magnetic stratigraphy in Cores 352-U1439A-1H through 10H (0-85 mbsf). Magnetic chrons downhole to the Gilbert Chron ( 4.5 Ma) were clearly identified. The identification of older chrons downhole to Chron $3 \mathrm{~B}$ is less certain. Cores $15 \mathrm{X}$ through $19 \mathrm{X}$ show clear magnetic polarity zones tentatively correlated with Chrons 8 through 13 ( 25-34 Ma).

Igneous rock samples from Hole U1439C have mostly low inclinations with absolute values less than $\sim 30^{\circ}$ and an average of $\sim 5^{\circ}$. This is consistent with the hypothesis that the Izu-Bonin arc formed near the paleoequator. Several zones of outlier paleoinclinations occur near observed fault zones. These anomalous values may be explained by remagnetization or tectonic rotation.

\section{Downhole logging}

A $\sim 220 \mathrm{~m}$ interval of basement rocks in Hole U1439C was logged over a $\sim 18 \mathrm{~h}$ period with two tool strings, the triple comboMSS and FMS-sonic tool strings. Borehole conditions were relatively stable during logging operations, but weather conditions and sea state deteriorated as logging progressed. Spectral gamma ray, density, resistivity, magnetic susceptibility, sonic velocity, and microresistivity images were successfully acquired. Changes in the character and trend of these logs are used to define 7 logging units in this hole:

- Logging Unit 1 ( 180-189 mbsf) is characterized by increasing values in total gamma ray, resistivity, density, and velocity, in combination with decreasing magnetic susceptibility downhole.

- Logging Unit 2 ( 189-202 mbsf) shows decreases in density, resistivity, and magnetic susceptibility, whereas NGR is high relative to the units above and below.

- Logging Unit 3 ( 202-213 mbsf) exhibits overall decreases in resistivity, magnetic susceptibility, and gamma ray values with coincident discrete peaks in gamma ray and density.

- Logging Unit 4 ( 213-246 mbsf) is characterized by high-frequency variations in both resistivity and magnetic susceptibility, in combination with anticorrelated profiles of density and total gamma ray values.
- Logging Unit 5 ( 246-314 mbsf), the thickest of the logging units, is characterized by a wide range in magnetic susceptibility values, with a significant high in the uppermost $6 \mathrm{~m}$ of the unit.

- Logging Unit 6 ( 314-365 mbsf) is delineated from Unit 5 by a major washed-out zone. The resistivity, magnetic susceptibility, and velocity profiles through this interval are variable, which can, in part, be attributed to increased borehole rugosity.

- Logging Unit 7 ( 365-402 mbsf, the bottom of the logged interval), has limited data available but is differentiated from the overlying unit by higher values of resistivity, magnetic susceptibility, and total gamma ray values.

Overall, density, velocity, and resistivity increase with depth. Gamma ray and magnetic susceptibility values do not show such systematic changes with depth. The oriented microresistivity images show a wide range of features and textures in the walls of the borehole, including fracture networks, vesicles, and through-going planar features.

Although the logging unit boundaries do not correspond perfectly with the petrologic unit boundaries, there are clear relationships between the logging data and the physical properties and geochemistry of the core. Ongoing integration of the core and logging data sets will be essential in filling in some of the gaps in core recovery in the volcanic extrusive sequence of this hole.

\section{Site U1440 summary}

\section{Operations}

After an $8.2 \mathrm{nmi}$ transit from Site U1439, the vessel arrived at Site U1440 (proposed Site BON-1A; Figure F8) and a positioning beacon was deployed at $0548 \mathrm{~h}$ on 9 August 2014. Site U1440 consists of two holes. Hole U1440A was cored with the APC to $103.5 \mathrm{mbsf}$ and then cored with the XCB to a final depth of 106.1 mbsf (Table T1). Nonmagnetic core barrels were used with all APC cores. Cores $352-\mathrm{U} 1440 \mathrm{~A}-1 \mathrm{H}$ through $6 \mathrm{H}$ were oriented using the FlexIT tool, which was removed with Core $7 \mathrm{H}$ as a result of the high heave conditions experienced by the vessel. APCT-3 temperature measurements were taken with Cores $4 \mathrm{H}, 6 \mathrm{H}, 8 \mathrm{H}$, and $11 \mathrm{H}$. Basement contact was recorded at $\sim 101$ mbsf. The APC coring system was deployed 12 times, with $103.5 \mathrm{~m}$ cored and $96.4 \mathrm{~m}$ recovered (93\%). The XCB coring system was deployed twice, with $2.6 \mathrm{~m}$ cored and $0.2 \mathrm{~m}$ recovered $(8 \%)$. The total time spent in Hole U1440A was $49.25 \mathrm{~h}$.

A reentry system with a reentry cone and $99 \mathrm{~m}$ of 10.75 inch casing was drilled into the seafloor in Hole U1440B using a mud motor, underreamer, and drilling bit assembly. Coring with the RCB began at 102.3 mbsf in Hole U1440B and was terminated after bit failure at a final depth of $383.6 \mathrm{mbsf}$ (Table T1). Basement contact was estimated at $\sim 125$ mbsf. The RCB coring system was deployed 36 times, with $281.3 \mathrm{~m}$ cored and $34.7 \mathrm{~m}$ recovered (12\%). Following coring, two logging runs were made with the triple combo-Ultrasonic Borehole Imager (UBI) and FMS-sonic tool strings. As a result of deteriorating hole conditions, the triple combo-UBI tool string collected data downhole to $253 \mathrm{mbsf}$, and the FMS-sonic tool string collected data to $\sim 243 \mathrm{mbsf}$. The total time spent in Hole U1440B was $364.75 \mathrm{~h}$. The acoustic beacon was recovered at $0612 \mathrm{~h}$ on 26 August, and the vessel returned to Site U1439. The total time spent at Site U1440 was 414 h or 17.25 days.

\section{Sedimentology}

Sediment and sedimentary rocks were recovered from the seafloor to 103.5 mbsf in Hole U1440A, beneath which a thin interval 
of basic volcanic rocks was recovered. The sediment represents a section through the early Oligocene to recent deep-sea sedimentary cover of the IBM fore-arc basement. The underlying basaltic rocks recovered here are interpreted as representing the fore-arc basement. The sedimentary succession in Hole U1440A is divided into three lithologically distinct units (Figure F13). Unit I is further divided into three subunits, and Unit II is divided into two subunits. The main criteria used to define the lithologic units and subunits are a combination of primary lithology, grain size, color, and diagenesis.

- Unit I (0-32.98 mbsf) is recognized mainly on the basis of a relatively high abundance of poorly consolidated brown mud.

Figure F13. Lithostratigraphic sediment units and ages based on biostratigraphy.

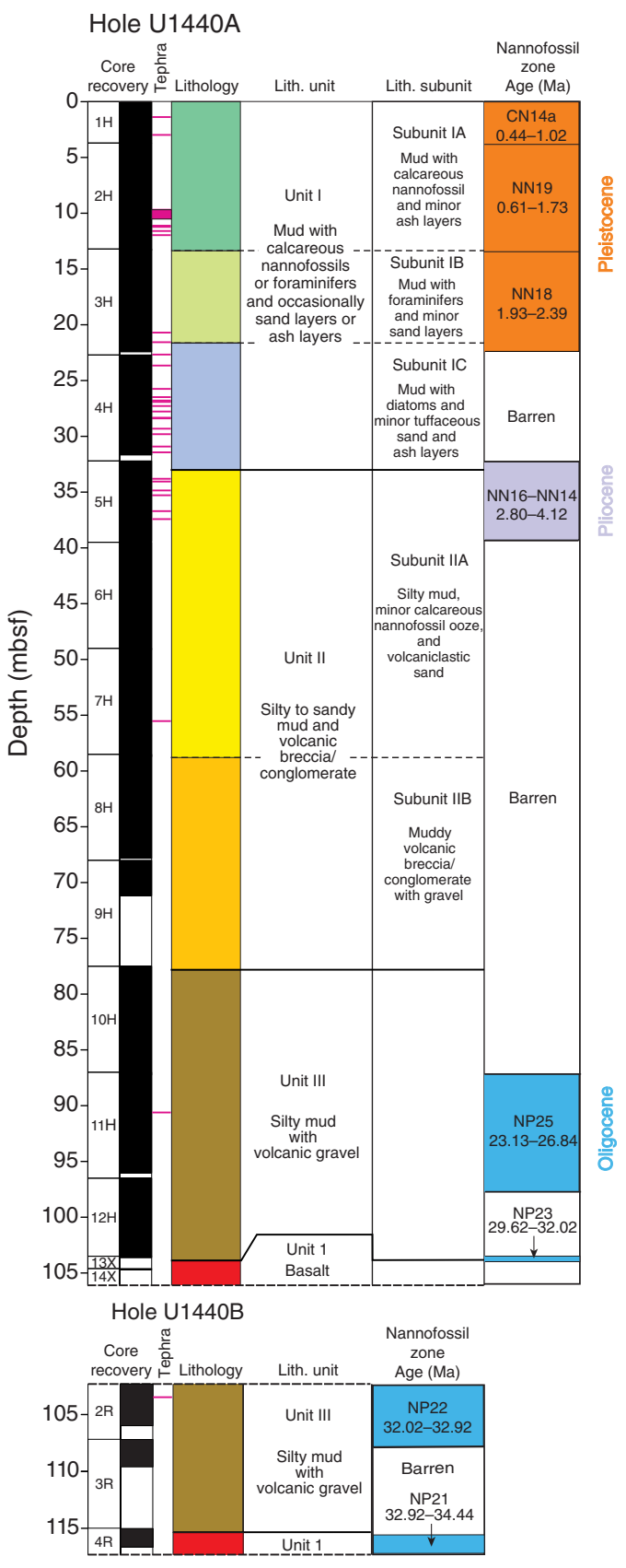

- Subunit IA (0-13.33 mbsf) is composed of mud with calcareous nannofossil and ash layers.

- Subunit IB (13.33-21.61 mbsf) is composed of mud with foraminifers and minor ash layers.

- Subunit IC comprises mud with diatoms, together with minor tuffaceous sandstone and ash layers (21.61-32.98 mbsf).

- Unit II (32.98-77.50 mbsf) is recognized on the basis of a downward increase in grain size to more clastic and volcanogenic sediment.

- Subunit IIA (32.98-58.50 mbsf) is relatively coarse grained and volcanogenic.

- Subunit IIB (58.50-77.50 mbsf) is even coarser grained and includes muddy volcanogenic breccia/conglomerate with gravel.

- Unit III (77.50-103.52 mbsf) exhibits a return to finer grained silty mud with subordinate volcanogenic gravel. The basalt beneath forms the top of the basement.

The proportions of the main sediment types recovered are

- Ash/tuff $=2.89 \mathrm{~m}$ or $2.9 \%$ of the total recovered sediments,

- Coarse-grained sediment (sand to conglomerate) $=16.5 \mathrm{~m}$ or $17.1 \%$,

- Fine-grained mud, silt/mudstone, and siltstone $=75.51 \mathrm{~m}$ or $78.5 \%$, and

- Nannofossil ooze $=1.24 \mathrm{~m}$ or $1.2 \%$.

In addition, sediment was recovered in three cores immediately below the drilled interval in Hole U1440B (Cores 2R through 4R; 102.3 to $115.3 \mathrm{mbsf}$ ). These cores correspond to Unit III in Hole U1440A.

\section{Biostratigraphy}

Calcareous nannofossils were recovered intermittently in Hole U1440A, where productive intervals are interspersed with barren intervals dominated by siliceous microfossils (especially radiolarians) and volcaniclastic material. There is a long barren interval from Sample 352-U1440A-6H-CC to $10 \mathrm{H}-\mathrm{CC}$. The youngest age obtained is Late Pleistocene (Subzone CN14a; 0.44-1.02 Ma), and the oldest age obtained is early Oligocene (Zone NP23; 29.62$32.02 \mathrm{Ma}$ ) (Figure F13). Three samples were examined from Hole U1440B. Samples 352-U1440B-2R-CC and 4R-1, 14-15 cm, contained calcareous nannofossils sufficient for age diagnostics, whereas Sample 3R-CC was barren. Preservation was moderate to poor in each sample, with many taxa showing strong dissolution and overgrowth. Both of the Hole U1440B samples have an early Oligocene age (Zones NP22 and NP21, respectively), with a range that is difficult to constrain better than $32.02-34.44$ Ma given the lack of reliable marker taxa for the equatorial Pacific. Absolute age determinations were more difficult to make at Site U1440 compared to Site U1439 as a result of increased dissolution and a number of barren intervals.

\section{Fluid geochemistry}

Twelve samples (1 per core) were collected in Hole U1440A for headspace hydrocarbon gas analysis as part of the standard shipboard safety monitoring procedure, and 12 whole-round samples were collected for interstitial water analyses (1 per core). No headspace gas or interstitial water samples were collected in Hole U1440B. All interstitial water samples were analyzed for salinity, alkalinity, $\mathrm{pH}, \mathrm{Cl}^{-}, \mathrm{Br}^{-}, \mathrm{SO}_{4}{ }^{2-}, \mathrm{Na}^{+}, \mathrm{K}^{+}, \mathrm{Ca}^{2+}, \mathrm{Mg}^{2+}$, and $\mathrm{PO}_{4}{ }^{3-}$.

Only minor methane was detected in the headspace gas samples. The highest methane concentration (5.84 ppmv) was mea- 
sured in Core 352-U1440A-1H at $1.5 \mathrm{mbsf}$ and may be attributed to the decomposition of organic matter in the uppermost layers of the sediment.

The major result of the interstitial water analyses from Hole $\mathrm{U} 1440 \mathrm{~A}$ is the distinctive behavior of $\mathrm{Mg}^{2+}$ and $\mathrm{Ca}^{2+}$. Both elements have seawater concentrations at the top of the hole, but $\mathrm{Ca}^{2+}$ concentrations then decrease with depth to $41.2 \mathrm{mM}$ at the bottom of the hole, whereas $\mathrm{Mg}^{2+}$ concentrations increase to $36.6 \mathrm{mM}$. These variations are independent of lithologic units and are attributed to pervasive fluid input from the underlying hydrothermally altered basaltic basement and alteration of volcanic ash in the sediment.

\section{Petrology}

Igneous rocks were recovered in both Holes U1440A and U1440B. Hole U1440A tagged basement during XCB coring with low recovery (Cores 352-U1440A-13X and 14X; 0.2 m recovered). Hole U1440B penetrated $268.3 \mathrm{~m}$ of igneous basement, again with low recovery (Cores 352-U1440B-4R through 36R; $33.9 \mathrm{~m}$ recovered). The basement/sediment contact is marked in both holes by a Mn-rich sediment layer or coating. The uppermost igneous unit in both holes comprises a mixture of volcanic rock fragments in a sediment matrix and likely represents talus or volcaniclastic breccia. This unit is $\sim 35 \mathrm{~cm}$ thick and underlain by more than $175 \mathrm{~m}$ of volcanic rock, which transitions over $\sim 70 \mathrm{~m}$ into dikes at $329.0 \mathrm{mbsf}$. The dikes are interpreted as part of a sheeted dike complex. The igneous basement is divided into 15 igneous units numbered in order of increasing depth (including the uppermost breccia) based largely on the physical nature of recovered lithologies, which were interpreted to be hyaloclastites, pillow lavas, sheet flows, and dikes (Figure F14).

Igneous rocks at Site U1440 are typically aphyric to sparsely phyric, plagioclase-pyroxene-magnetite phyric basalts with intergranular to intersertal textures. The coarser grained units in the dike complex and transition zone are dolerites with subophitic textures. All of the igneous rocks are petrographically similar to IBM FAB collected elsewhere and have chemical compositions consistent with this classification. They are distinct petrographically and chemically from the boninite-suite lavas, which are typically orthopyroxene and olivine phyric.

The degree of alteration of the igneous rocks at Site U1440 is low in the volcanic section where the secondary mineralogy is dominated by calcite, smectite-group clays, and zeolites including phillipsite. These minerals form abundant veins in Cores 352-U1440B$12 \mathrm{R}$ through $24 \mathrm{R}$, some of which are associated with pyrite and native copper. Alteration becomes more intense in the transition zone and dike complex. Secondary minerals typically only replace the groundmass phases, leaving the silicate framework minerals (plagioclase and pyroxene) unaffected, except in the lower part of the dike complex where pyroxene and plagioclase may be partially replaced. Glass is commonly devitrified and, less commonly, replaced by palagonite, clays, and zeolite.

\section{Rock geochemistry}

Whole-rock ICP-AES chemical analyses were performed on 33 igneous rocks and 16 sediment samples representative of the different lithologic units recovered at Site U1440. Twelve sediment samples were collected from Hole U1440A (1 per core), and three samples were collected in the deepest part of the sediment sequence in Hole U1440B from 104.4 to 115.1 mbsf. Additionally, one sandstone piece was recovered within the igneous sequence in Section 352-U1440B-15R-1 (192.8 mbsf). One aphyric basalt sample was collected at the bottom of Hole U1440A, and 32 samples, mostly basaltic, were collected in Hole U1440B. The 16 sediment samples were analyzed for major and trace element concentrations and volatile contents. The 33 igneous rocks were analyzed for major and trace element concentrations. An aliquot of the powder used for ICP-AES analyses was subsequently used for pXRF analyses.

The sediment sampled at Site U1440 is dominantly silty mud, and its compositional variations reflect sedimentary unit changes. The range of compositions is more restricted than in the sediment in Hole U1439A. The sediment has, on average, low $\mathrm{CaO}$ contents ( $<2 \mathrm{wt} \%)$, high $\mathrm{SiO}_{2}$ contents ( $>55 \mathrm{wt} \%$ ), and variable Cu concentrations (120-240 ppm). A few samples contain slightly higher carbonate contents with total $\mathrm{C}$ contents $>0.9 \mathrm{wt} \%, \mathrm{CaO}$ of $5-22 \mathrm{wt} \%$, and lower $\mathrm{Cu}$ concentrations (70-90 ppm). Hole U1440B sediment has the same composition as that of lithologic Unit III sediment in Hole U1440A. Similarly, the sandstone recovered within igneous Unit 4 rocks overlaps in composition with lithologic Unit III sediment. This sandstone could represent an accidental fragment displaced by drilling or an accumulation of sand in an open fracture.

Site U1440 igneous rocks are mostly basalts with one andesite unit (igneous Unit 6). $\mathrm{SiO}_{2}$ ranges from 48 to $57 \mathrm{wt} \%$, and total alkali $\left(\mathrm{Na}_{2} \mathrm{O}+\mathrm{K}_{2} \mathrm{O}\right)$ contents vary from 2.1 to $3.2 \mathrm{wt} \%$. These rocks are relatively depleted in incompatible trace elements (e.g., $\mathrm{TiO}_{2}=0.6-$ $1.4 \mathrm{wt} \%)$ and have highly variable $\mathrm{Cr}$ concentrations (15-380 ppm), indicating different degrees of differentiation. Downhole profiles of major element compositions exhibit a distinct increase in $\mathrm{SiO}_{2}$ concentrations and Mg\# at 260 mbsf. This depth marks the transition between igneous Units 7 and 8, which is interpreted as the boundary between the volcanic series and the lava/dike transition. The sampled igneous rocks have major element compositions similar to those of FAB collected by diving in the Bonin fore arc (cf. Ishizuka et al., 2011).

XRF chemostratigraphic analyses were conducted on archivehalf pieces of cores and on thin section billets and powders. The results of these chemical analyses, in conjunction with observations on core material and thin sections carried out by the petrology team, contributed to the 15 unit lithologic division of the lavas and dikes and are discussed in Preliminary scientific assessment. Briefly, $\mathrm{TiO}_{2}$ and $\mathrm{Zr}$ concentrations in basalts generally decrease downhole from Unit 4. Although there is some cyclicity, Cr concentrations and $\mathrm{Sr} / \mathrm{Zr}$ ratios increase over the same interval. Above Unit 4 the basalts have low $\mathrm{Zr}, \mathrm{TiO}_{2}$, and $\mathrm{Cr}$ concentrations and relatively high $\mathrm{Sr} / \mathrm{Zr}$ ratios. Unit 6 andesites are characterized by low $\mathrm{TiO}_{2}$ and $\mathrm{Sr}$ concentrations and the highest $\mathrm{Zr}$ concentrations of any lavas from Sites U1440 and U1441.

\section{Structural geology}

Bedding planes in the sediment are marked by dark pyroclastic beds and thin sandy layers and lay generally subhorizontal. Drillinginduced deformation of core features precluded meaningful structural measurements in the sediment between $~ 57$ and $102 \mathrm{mbsf}$. In the igneous rocks, magmatic fabrics are rare and limited to a few centimeter-wide domains of grain alignment. Steep, metamorphic, chlorite-based foliation overprints primary fabrics at $\sim 145-146$, 281-291, and 358-369 mbsf. Tension veins filled with (Mg-) calcite, zeolite, chlorite, and clays are common at $\sim 164-166,202-264$, and 319-369 mbsf. These veins typically form two sets at a high angle from each other with average dips of $\sim 40^{\circ} \pm 10^{\circ}$ and $80^{\circ} \pm 10^{\circ}$. The basalts and dolerites are overall free of plastic and cataclastic deformation features such as slickensides. 
Figure F14. Lithostratigraphic igneous units.

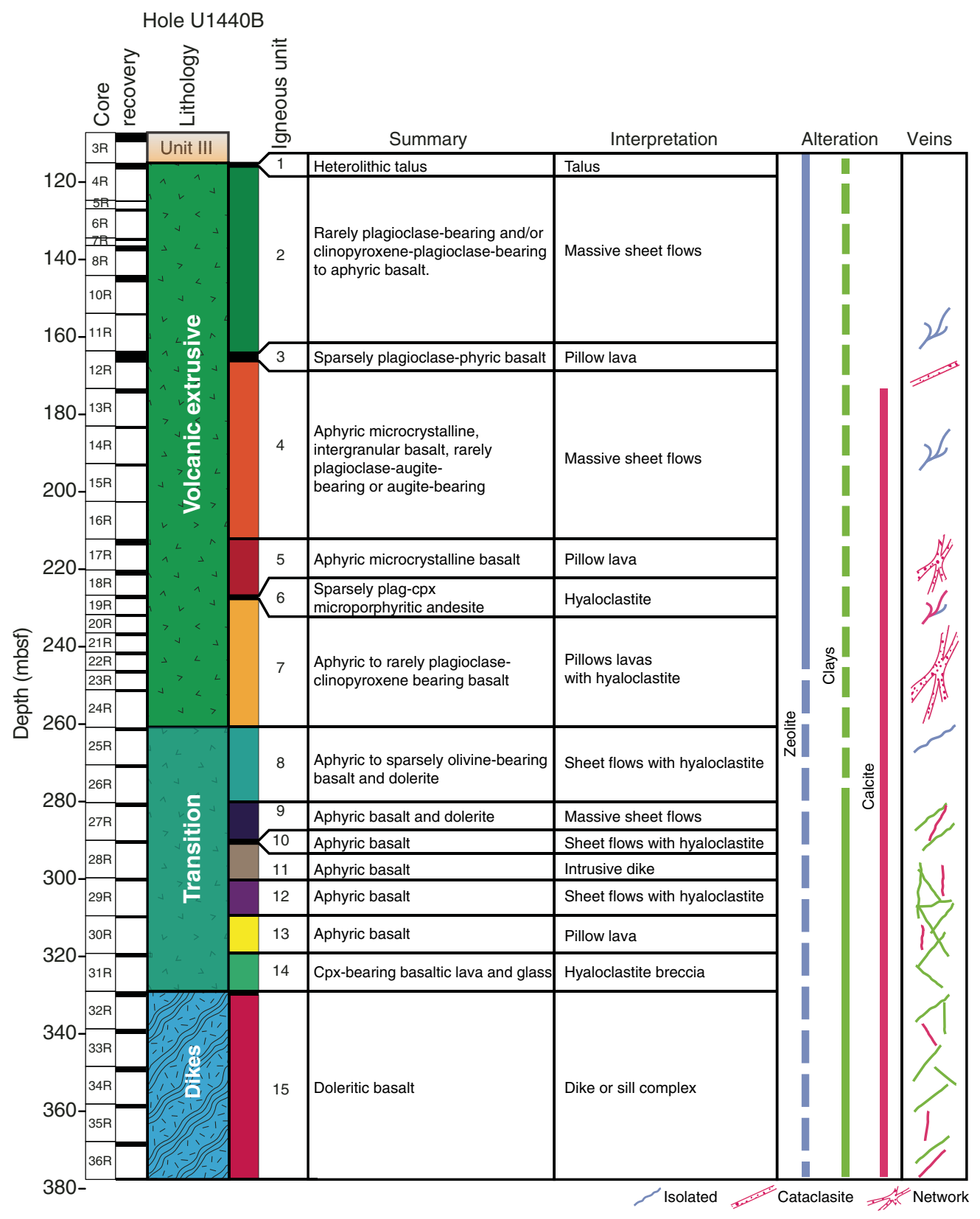

\section{Physical properties}

Changes in the trends of physical properties are encountered at similar depths, and these changes tend to be associated with different units. At $\sim 10 \mathrm{mbsf}$ in lithologic Unit I, there is a positive spike in $P$-wave velocity and NGR accompanied by a slight increase of gamma ray attenuation (GRA) density. This is an interval rich in tephra layers. At 35-40 mbsf in Unit II, $P$-wave velocity and GRA density increase sharply, whereas NGR decreases. Color reflectance parameters $L^{*}, a^{*}$, and $b^{*}$ decrease in the same interval. Physical properties show significant variability in Unit III. At $83-87 \mathrm{mbsf}$, magnetic susceptibility increases suddenly and color reflectance parameter $L *$ decreases. At $\sim 87-100$ mbsf, $P$-wave velocity increases; magnetic susceptibility and NGR are variable but generally decrease with depth; color reflectance parameters decrease with depth; GRA, dry, and bulk density increase with depth; and porosity decreases with depth. At 100-102 mbsf, $P$-wave velocity, magnetic susceptibility, NGR and GRA, and dry and bulk density suddenly decrease accompanied by a sudden increase in porosity. Physical property parameters change in igneous Units 7 and 8 . At $\sim 230$ mbsf in Unit 7, porosity decreases sharply, $P$-wave velocity increases, and bulk and dry density increase. At 270-280 mbsf in Unit 8, NGR decreases and magnetic susceptibility increases, with high values observed between $280 \mathrm{mbsf}$ and the bottom of the hole.

\section{Paleomagnetism}

Remanent magnetization measurements reveal that sediment cored at Site U1440 is highly magnetic $(\sim 0.1-2 \mathrm{~A} / \mathrm{m}$ natural remanent magnetization [NRM]), apparently as a result of input of volcaniclastic material from nearby sources. A normal PliocenePleistocene magnetic stratigraphy has been established for the up- 
per sedimentary section and includes the period from the upper Gilbert Chron ( 4 Ma) to the Brunhes Chron at the surface. Paleomagnetic samples from the igneous basement section reveal a probable magnetic reversal sequence. The upper $\sim 50$ and lower $\sim 120 \mathrm{~m}$ of the section have normal polarity, whereas the intervening $\sim 70 \mathrm{~m}$ has reversed polarity. Until radiometric dates are available for the basement section, the pattern cannot be correlated with the geomagnetic polarity timescale.

\section{Downhole logging}

A 130 m open hole interval of Hole U1440B was logged over a $\sim 24$ h period with two tool strings, the triple combo-UBI and the FMS-sonic. Although borehole conditions deteriorated while downhole logging was in progress, spectral gamma ray, density, resistivity, sonic velocity, and microresistivity images were successfully acquired.

Seven logging units are defined on the basis of the character and trend of the various logs. Logging Unit 1 ( 99-116 mbsf) is characterized by relatively consistent resistivity and velocity with depth whereas the underlying Unit 2 ( 116-122 mbsf) shows sharp increases in gamma ray, resistivity, and density downhole. Units 3 ( 122-164 mbsf) and $5(\sim 170-211 \mathrm{mbsf})$ exhibit similarities in their log responses, steadily increasing in resistivity with depth and with no net change in gamma ray values. However, Unit 3 does show much greater variability in bulk density compared to the range of densities measured in Unit 5. Units 4 ( 164-170 mbsf) and 6 ( 211-222 mbsf) are relatively thin by comparison to Units 3 and 5 and are characterized by high resistivity, high velocity, and increasing density with depth. Unit 7 has limited data available but is differentiated from the overlying unit by a marked changed in the character of the resistivity log. Overall, there are downward increases in density, resistivity, and sonic velocity, whereas gamma ray values and porosity (as derived from resistivity) exhibit decreasing downhole trends. Microresistivity images overall echo the increasing resistivity with depth and also elucidate a range of textures and features through the logged interval.

Preliminary analysis of the data shows a reasonable agreement between the logging unit boundaries and the lithologic unit boundaries that were defined on the basis of core description and geochemical analyses. It is anticipated that the logging data, although only available for the lowermost sedimentary interval and upper volcanic extrusive section, will be useful in filling in some of the gaps in core recovery.

\section{Site U1441 summary}

\section{Operations}

The JOIDES Resolution completed the $6.2 \mathrm{nmi}$ transit from Site U1439 in dynamic positioning mode while the drill string was being lowered to the seafloor. The vessel arrived at Site U1441 (proposed Site BON-6A) at $1512 \mathrm{~h}$ on 11 September 2014, and a seafloor positioning beacon was deployed.

Site U1441 consists of one hole. An RCB BHA was assembled with a C-4 bit. Hole U1440A was spudded at 2245 h on 11 September. The RCB coring system with nonmagnetic core barrels was deployed 22 times (Cores 352-U1441A-1R through 22R) and the hole was advanced to $205.7 \mathrm{mbsf}$ (Table T1). Cores 11R and 12R had no recovery as a result of a plugged bit. Hole U1441A was terminated as a result of poor core recovery, the rubbly nature of the formation, and high risk of getting stuck. The RCB cores recovered $50.7 \mathrm{~m}$ over the $205.7 \mathrm{~m}$ cored interval (25\%). The total time spent in Hole U1441A was $75.75 \mathrm{~h}$. The seafloor positioning beacon was recovered at $0914 \mathrm{~h}$ on 14 September, and the vessel started the slow transit to Site U1442 while continuing to pull the drill string to the surface.

\section{Sedimentology}

Pelagic and volcaniclastic sediment was recovered from the seafloor to 83.00 mbsf, beneath which igneous rocks were recovered. The sedimentary succession is divided into five lithologically distinct units (Figure F15). Lithologic Unit I is further divided into two subunits. The volcanic rocks beneath are interpreted as the fore-arc basement. The main criterion for the recognition of the lithologic units and subunits is a combination of primary lithology, grain size, color, and diagenesis. Within the overall succession, 16 ash or tuff

Figure F15. Lithostratigraphic sediment units and ages based on biostratigraphy.

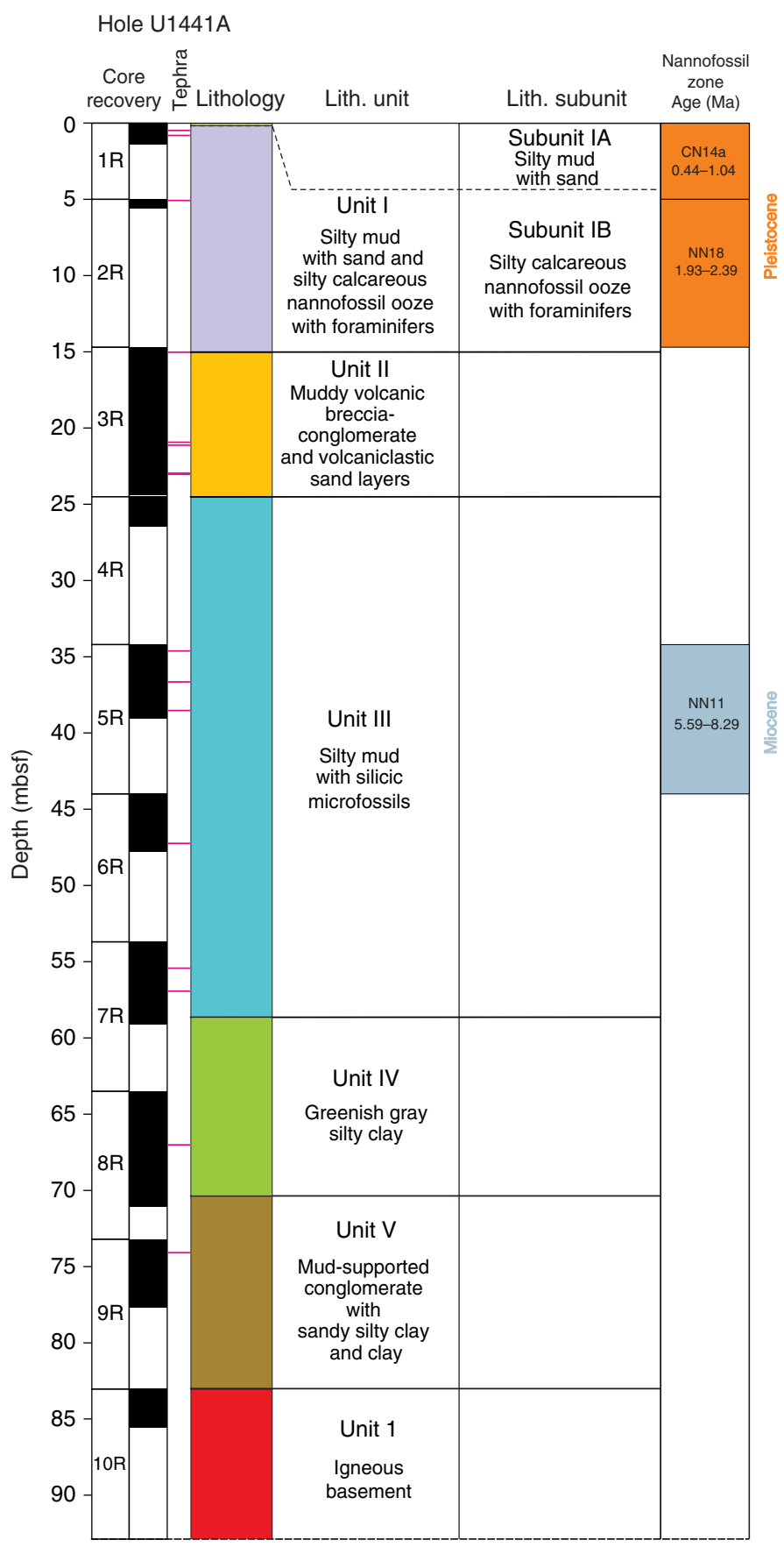


layers were observed. The bedding planes are generally oriented subhorizontally, with dip angles $<10^{\circ}$.

- Unit I (0-15.02 mbsf) is divided into 2 subunits.

- Subunit IA (0-0.17 mbsf) is recognized by the occurrence of brownish mud with medium to coarse sand.

- Subunit IB (0.17-15.02 mbsf) is a relatively nannofossil-rich interval of silty calcareous ooze with nannofossils and sparse planktonic foraminifers.

- Unit II (15.02-24.50 mbsf) is recognized on the basis of a downward change to more clastic-rich sediment composed of muddy volcanic breccia/conglomerate and volcaniclastic sand layers.

- Unit III (24.50-58.64 mbsf) is characterized by a return to finer grained silty mud with relatively abundant radiolarians.

- Unit IV (58.64-70.38 mbsf) is distinguished by a distinct downward change to greener, relatively fine-grained sediment dominated by greenish gray silty clay.

- Unit V (70.38-83.00 mbsf) is a much coarser, mud-supported conglomerate with sandy and silty clay and also clay.

\section{Biostratigraphy}

Calcareous nannofossils were present in 3 of 10 core catcher samples. Samples 352-U1441A-1R-CC and 2R-CC are nannofossil oozes, whereas siliceous fossils dominate Sample 5R-CC. Preservation was moderate to good in each sample. Samples $1 \mathrm{R}-\mathrm{CC}$ and $2 \mathrm{R}-$ $\mathrm{CC}$ yield an approximately Late Pleistocene age, whereas Sample 5R-CC yields an approximately late Miocene age (5.59-8.29 Ma). The widespread presence of radiolarians in the lower part of the sediments will help us improve the biostratigraphy postcruise.

\section{Fluid geochemistry}

Ten samples were collected from Hole U1441A for headspace hydrocarbon gas analysis as part of the standard shipboard safety monitoring procedure. Methane concentrations range from 1.08 to 1.29 ppmv, and neither ethane nor propane were detected.

\section{Petrology}

All of the igneous rocks at Site U1441 are FAB similar to those drilled at Site U1440. These basalts are also similar texturally and chemically to FAB recovered in diving expeditions in the region. They are dominated by modal plagioclase, clinopyroxene, and magnetite in the groundmass, and most are aphyric. Four units were identified based on hand specimen and thin section description and XRF data (Figure F16). Microphenocrysts of plagioclase are rare, but igneous Unit 3 contains $2 \%-3 \%$ clinopyroxene phenocrysts. Not surprisingly, Unit 3 is also the unit with the highest $\mathrm{CaO}$ content. Three chemical varieties of basalt were found. The upper basalts (Units 1 and 2) are depleted in $\mathrm{TiO}_{2}$ and $\mathrm{Zr}$ and have low $\mathrm{Cr}$ concentrations. The lowest basalts, which comprise Unit 4, are normal FAB very close in composition to those at Site U1440. In contrast, the Unit 3 basalts, which lie stratigraphically between these types, are among the most depleted basalts found along the IBM fore arc, with very low $\mathrm{TiO}_{2}$ and $\mathrm{Zr}$ concentrations and high $\mathrm{Ti} / \mathrm{Zr}$ ratios. With the exception of Unit 3, $\mathrm{TiO}_{2}, \mathrm{Zr}$, and $\mathrm{Cr}$ all show subtle increases steadily downhole.

\section{Rock geochemistry}

Seven igneous rocks from Cores 352-U1441A-10R to 22R were analyzed by ICP-AES for major and trace elements and by CHNS for $\mathrm{CO}_{2}$ and $\mathrm{H}_{2} \mathrm{O}$ contents. The igneous rocks recovered have LOIs of 2.0-4.6 wt\%. They have higher $\mathrm{H}_{2} \mathrm{O}$ contents in the upper part of the basement (Unit 1) and relatively uniform $\mathrm{H}_{2} \mathrm{O}$ contents of 2.0$2.5 \mathrm{wt} \%$ in the lower units.
The igneous rocks recovered from Hole U1441A are all basalts, with $\mathrm{SiO}_{2}$ concentrations of $49-51 \mathrm{wt} \%$ and total alkali contents of $2-4 \mathrm{wt} \%$. Overall, the major element composition of Site U1441 basalts is relatively homogeneous with $\mathrm{MgO}$ of $6.4-8.4 \mathrm{wt} \%, \mathrm{CaO}$ of 10.7-11.6 wt\%, and $\mathrm{Fe}_{2} \mathrm{O}_{3}$ of $10.8-12$ wt\%. Site U1441 basalts are very similar in composition to the IBM FAB previously recovered by drilling at Site U1440 and by diving. The single sample analyzed from Unit 3 has high $\mathrm{Cr}$ and $\mathrm{CaO}$ concentrations, high $\mathrm{Mg \#}$, and low concentrations of $\mathrm{TiO}_{2}, \mathrm{Zr}$, and $\mathrm{Y}$. This sample plots as a magnesian end-member composition on trace element variation diagrams but, despite its lower Ti contents, is both geochemically and petrographically distinct from Site U1439 boninites.

Alteration in Hole U1441A ranges from moderate to highly altered and tends to decrease downhole. The secondary assemblage consists of smectite group clays and zeolites with minor calcite (Figure F17). Clay minerals are dominant in the top half of the hole and downhole to Core 352-U1441A-16R. In the lower half of the hole, zeolite becomes the most abundant alteration mineral in the groundmass.

\section{Structural geology}

In the igneous units, viscous-plastic fabrics related to magmatic flow are rare and limited to millimeter- to centimeter-wide domains, defined primarily at the micro scale. These domains are relatively common in the lower parts of Hole U1441A (e.g., in Sections 352-U1441A-19R-1 and 22R-1). The magmatic foliation is mainly defined by the shape-preferred orientation of acicular feldspar crystals embedded within a glassy or microcrystalline matrix.

Extensional fractures without mineral fillings are subvertical and are observed at 85.15 and 180.45 mbsf. Subvertical to inclined, whitish, crystalline, millimeter-thick veins are abundant at $122.22-$ 141.43 and 190.2-190.6 mbsf. In the lower interval the veins form steeply inclined conjugate sets. The vein-filling material consists of (Mg-) calcite and/or zeolite and/or chlorite.

Slickensides are abundant at $84.00-88.25$ mbsf and dip steeply to subvertically. The general sense of shear is left-lateral strike-slip to oblique reverse, the latter including a left-lateral component as well. One subhorizontal slickenside shows a normal sense of shear. In the lowermost sections of Hole U1441A (interval 20R-1, 15-27 $\mathrm{cm}$ ), a semiductile to brittle, low-angle shear zone was observed within a highly altered domain. The shear zone was recovered as a single piece with an oblong shape, without a preserved contact with the wall rock. Its position within the lithostratigraphic sequence cannot be defined exactly because of poor core recovery. The recovered basalt pieces below and above do not show any indication of comparable alteration or deformation. Within the shear zone, shear bands form subparallel sets, indicating a top-down sense of shear.

\section{Physical properties}

Many of the physical properties display similar downhole trends in the sedimentary section. $P$-wave velocities have peaks as high as $1580 \mathrm{~m} / \mathrm{s}$ at 22-24 mbsf (lithologic Unit II) and $1540 \mathrm{~m} / \mathrm{s}$ at 56-58 mbsf (Unit III). Magnetic susceptibility values also have peaks to 250-300 IU at the same depths. These peaks in $P$-wave velocities and magnetic susceptibility values correspond to tephra layers. GRA densities are $1.4-1.5 \mathrm{~g} / \mathrm{cm}^{3}$, and NGR values are $10-20$ counts/s from 0 to $69 \mathrm{mbsf}$. All of these parameters have a high peak at $70 \mathrm{mbsf}$ at the bottom of Unit IV. Porosities are $65 \%-85 \%$ from 0 to 78 mbsf. Porosities are higher than $80 \%$ in Unit II and have the lowest value of $70 \%$ in Unit III.

Physical properties typically exhibit stepwise increases between Units 1 and 2. Magnetic susceptibility values start at $>1000 \mathrm{IU}$ at the 
Figure F16. Lithostratigraphic igneous units.

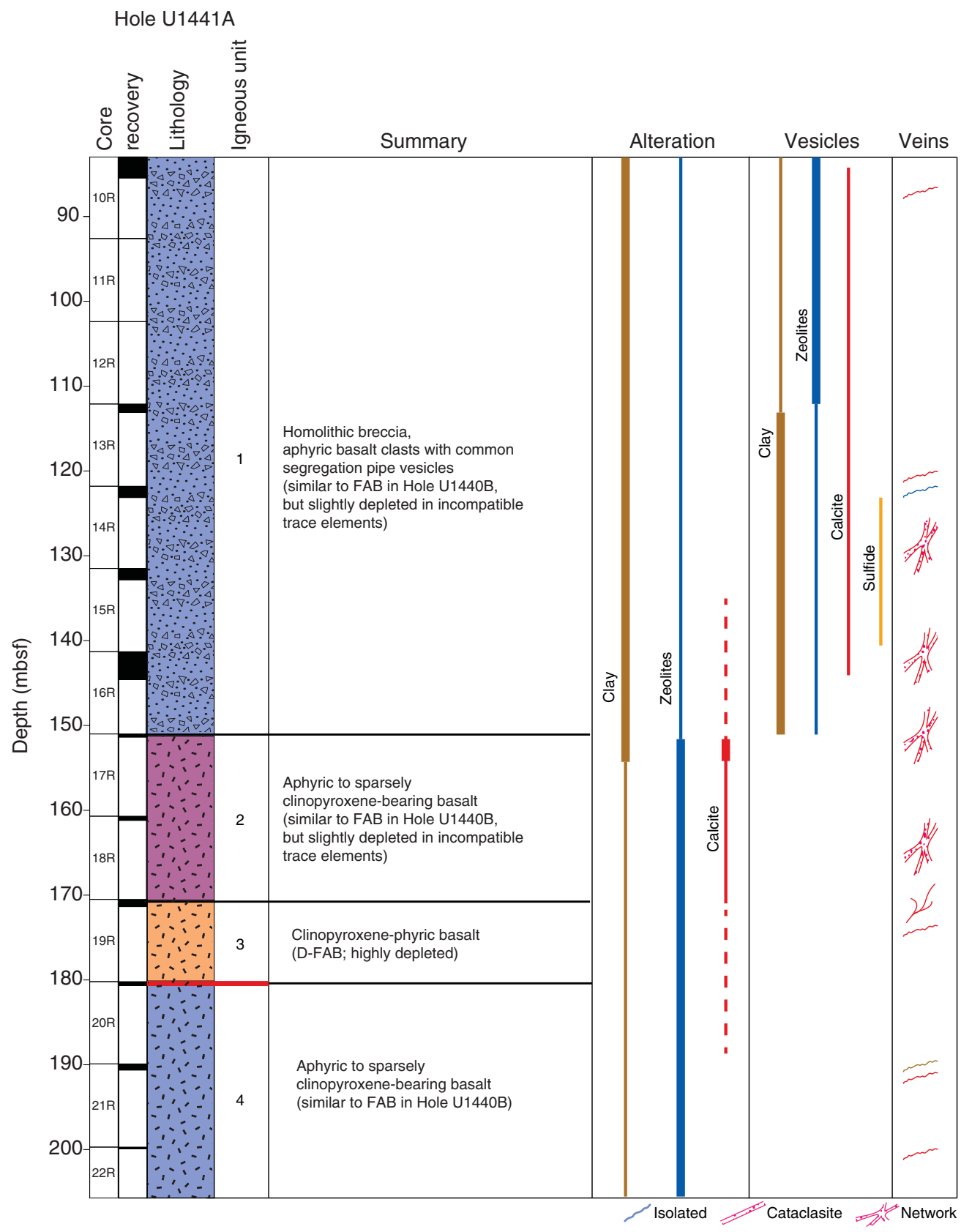

top of the basement, at $~ 85$ mbsf in Unit 1, and decrease to 500 IU in Units 2-4. GRA density values are $2-2.5 \mathrm{~g} / \mathrm{cm}^{3}$ with a peak of 2.7 $\mathrm{g} / \mathrm{cm}^{3}$ at $171 \mathrm{mbsf}$ in Unit 3. NGR values increase from 9 to 20 counts/s in Unit 1 and decrease to 5 counts/s in Units 2-4. Although the values of reflectance parameter $L^{*}$ remain steady at $50-$ 55 in Units $1-4$, both $\mathrm{a}^{*}$ and $\mathrm{b}^{*}$ values are high $(>10)$ in Unit 1 and low $(<5)$ in Units $2-4$. Bulk densities of the discrete samples are $2.4 \mathrm{~g} / \mathrm{cm}^{3}$ in Unit 1 and increase to $\sim 2.8 \mathrm{~g} / \mathrm{cm}^{3}$ in Units 2-4. Porosities are $\sim 30 \%$ in Unit 1 and decrease to $10 \%$ in Units $2-4$. P-wave velocities of discrete samples are $3000-4000 \mathrm{~m} / \mathrm{s}$ in Unit 1 and increase to $5500 \mathrm{~m} / \mathrm{s}$ in Units 2-4.

\section{Paleomagnetism}

The remanent magnetization of archive-half sediment sections from sediment Cores 352-U1441A-3R to 9R was measured with the cryogenic magnetometer. The magnetic inclinations of the sediments define normal and reversed polarity zones. The inclinations are steep, typically $>60^{\circ}$, which is probably the result of sediment disturbance by rotary coring. However, there are significant gaps in core recovery that hinder interpretation. In addition, the reversal pattern shows a small number of polarity zones, whereas there should be several on the basis of the biostratigraphic ages and the geomagnetic polarity timescale. Thus, we are unable to interpret the polarity record of the sediments in Hole U1441A.

The remanent magnetization was measured on 14 igneous rock samples from Cores 352-U1441A-10R to 22R. These samples have both normal and reversed polarities with two normal polarity zones at the top and bottom of the section bracketing a reversed polarity zone. The magnetic inclinations are close to that of the current field, implying that these rocks may have been remagnetized in the near 
Figure F17. Lithostratigraphic igneous units. Red hatched bars adjacent to lithology column represent fault zones. Opx $=$ orthopyroxene, OI $=$ olivine, Cpx $=$ clinopyroxene, $\mathrm{Pl}=$ plagioclase.

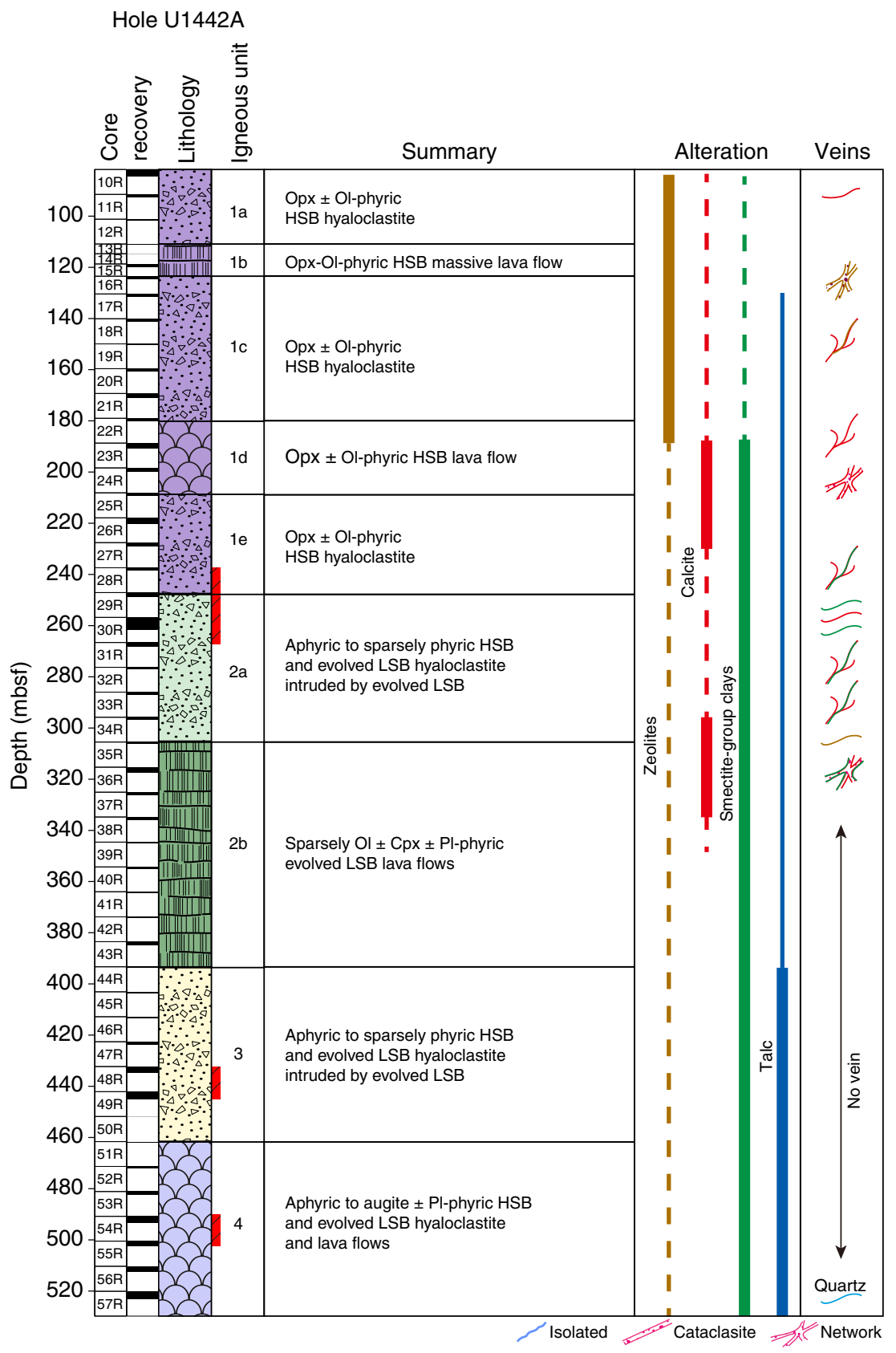

geologic past. Most of the samples are from igneous Unit 1 , which is thought to consist of talus, so the coherent inclinations are surprising. Therefore, remagnetization could explain the coherency of the jumbled pile of rocks.

\section{Operations}

\section{Site U1442 summary}

The JOIDES Resolution completed the $5.5 \mathrm{nmi}$ transit from Site U1441 in dynamic positioning mode while the drill string was being raised from the seafloor. The vessel arrived at Site U1442 (proposed Site BON-5A) at $1630 \mathrm{~h}$ on 14 September 2014, and a seafloor positioning beacon was deployed. The vessel then offset $500 \mathrm{~m}$ at an azimuth of $81^{\circ}$.
A RCB BHA was assembled with a C-4 bit and then lowered to the seafloor. Hole U1442A was spudded at $2320 \mathrm{~h}$ on 14 September $\left(28^{\circ} 24.5784^{\prime} \mathrm{N}, 142^{\circ} 37.3368^{\prime} \mathrm{E}\right.$; $3162 \mathrm{~m}$ water depth). The RCB coring system with nonmagnetic core barrels was deployed 57 times (Cores 352-U1442A-1R through 57R), with $529.8 \mathrm{~m}$ cored and $100.7 \mathrm{~m}$ recovered (19\%) (Table $\mathrm{T} 1$ ). The basement contact was at $\sim 82$ mbsf. A free-fall funnel was deployed on 19 September so that the RCB bit could be changed. The bit change occurred at $46.1 \mathrm{~h}$ of coring time. Hole U1442A was terminated when the time available for coring expired. The hole was then logged with the triple comboMSS tool string (to $371 \mathrm{mbsf}$ on the first pass and $305 \mathrm{mbsf}$ on the second pass) and the FMS-sonic tool string (to a maximum depth of 287 mbsf). The total time spent in Hole U1442A was 235.75 h. The 
seafloor positioning beacon was recovered at $0940 \mathrm{~h}$ on 24 September. After the thrusters were raised at $1030 \mathrm{~h}$ on 24 September, the vessel started the transit to Keelung, Taiwan.

\section{Sedimentology}

Pelagic and volcaniclastic sediments were recovered from the seafloor to $83.1 \mathrm{mbsf}$, beneath which igneous rocks were drilled. The sediment represents part of the late Oligocene to recent deepsea sedimentary cover of the Izu-Bonin fore arc, which is stratigraphically condensed because of its position on a basement high.

The recovered sedimentary succession is divided into 4 lithologically distinct units (Figure F18). Lithologic Unit III is divided into two subunits. The main criterion for the recognition of the lithologic units and subunits is a combination of primary lithology, grain size, color, and diagenesis. Within the overall succession, 21 ash or tuff layers were observed.

- Unit I (0-2.59 mbsf) is mostly silty to sandy nannofossil mud and nannofossil ooze, with additional dark gray "blotches" rich in volcanic glass that probably represent the remains of thin ashrich layers.

- Unit II (2.59-33.00 mbsf) is dominantly silty nannofossil ooze with slight color banding (off-white to pale brown), reflecting the presence of muddy and silty/sandy layers. The silty and sandy material is volcaniclastic in origin and is accompanied by several thin, discrete, ash layers, which are dispersed over tens of centimeter-thick intervals within the background sediment.

- Unit III (33.00-62.40 mbsf) is divided into 2 subunits.

- Subunit IIIA (33.0-52.60 mbsf) is recognized by the presence of brownish mud and nannofossil-rich mud.

- Subunit IIIB (52.60-62.40 mbsf) is relatively pure clay with some manganese-stained horizons and also nannofossil ooze intervals.

- Unit IV (62.40-83.12 mbsf) is distinguished by nannofossil-rich sediment, which becomes more lithified downward, and transitions to nannofossil chalk. This sediment contains variable amounts of clay, volcaniclastic silt/siltstone, and volcaniclastic fine sand/sandstone. The most clastic-rich sediment can be classified as nannofossil-bearing fine sand/sandstone.

The sedimentary succession is terminated downhole by a thin manganese layer, followed by a profound change to brownish red noncalcareous volcanogenic sandy and silty clay interspersed with clasts of mafic extrusive igneous rocks.

\section{Biostratigraphy}

Calcareous nannofossils were examined in core catcher Samples 352-U1442A-1R-CC to 9R-CC. An additional sample was taken from Section 10R-2, 22-23 cm, just above the layer containing igneous rocks. Preservation was moderate to good in each sample. A fairly continuous condensed section was recovered comprising sediments from the Eocene/Oligocene boundary up to as recent as the Late Pleistocene.

\section{Fluid geochemistry}

Ten samples were collected from sediment in Hole U1442A for headspace hydrocarbon gas analysis as part of the standard shipboard safety monitoring procedure. Only minor methane was detected (1.08-1.29 ppmv), and the relatively low and uniform methane concentrations imply negligible concentrations of organic matter. No ethane or propane was detected.
Figure F18. Lithostratigraphic sediment units and ages based on biostratigraphy.

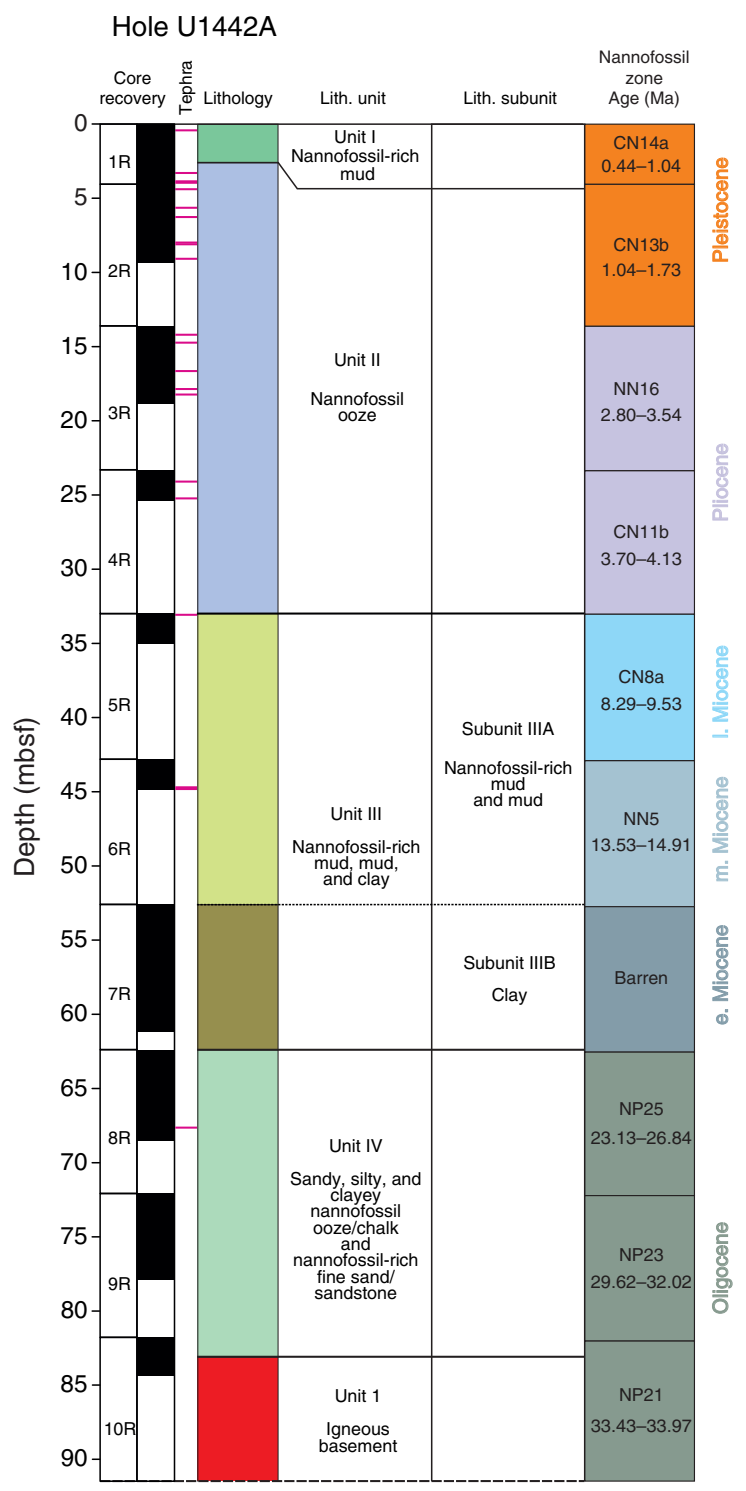

\section{Petrology}

Igneous rocks were recovered in Hole U1442A, which penetrated more than $440 \mathrm{~m}$ of igneous basement (Figure F17). The top of the igneous basement is defined by a Mn-rich sediment layer. The uppermost part of the section comprises breccia that may represent seafloor colluvium. This is underlain by boninitic lavas and hyaloclastites. Hole U1442A contains multiple zones of faulting.

Coring in Hole U1442A recovered igneous units similar to those in Hole U1439C, which lies $\sim 1.3 \mathrm{~km}$ to the west. Nevertheless, there are notable differences between the two holes. Hole U1442A recovered low- and high-silica boninites together with evolved low-silica boninites. However, unlike Hole U1439C, no dikes and no units dominated by basaltic boninites were encountered. Given the proximity of the two sites and the wealth of pXRF data, we correlated like units between the sites (see Preliminary scientific assessment). However, faults were encountered in Holes U1439C and U1442A, most indicating normal slip, but some had indicators of reverse and oblique strike-slip motion. These faults raise the possibil- 
ity that their stratigraphic records were disturbed and that the two sites were originally further apart. However, with the exception of the igneous Unit 1/2 boundary discussed below, units continued across fault surfaces at both holes suggesting that the stratigraphic record disturbance was minimal. We have no evidence for significant strike-slip motion between the sites, but such motion cannot be ruled out based on present knowledge.

Unit 1 (83-250 mbsf) consists mostly of hyaloclastites and lava flows of high-silica boninitic affinity. Unit 1 in Hole U1439C compositionally correlates with this unit but contains significantly less hyaloclastite. The most distinctive chemical feature of the upper section of Hole U1442A is the variable $\mathrm{Cr}$ content, which reaches values in excess of $1000 \mathrm{ppm}$. Below a fault zone at $240-270 \mathrm{mbsf}$, which separates Subunit 1e from Subunit 2a, Cr contents drop significantly and, with a few exceptions, remain below $500 \mathrm{ppm}$. Units 2-4 contain textural and compositional evidence of magma mingling, in which evolved boninite magma was intruded by lessevolved boninite magma. The subtle petrographic and chemical differences seen below Unit 1 were used to define subunits.

Finally, a striking feature of Hole U1442A is its excellent preservation in comparison to Site U1439. Fresh glass is pervasive throughout the entire igneous interval in Hole U1442A, making it an invaluable resource for postcruise research requiring fresh material.

In Unit 1 lava flows, the groundmass and some crystals are altered to variable degrees into smectites and carbonates (Figure F17). In Unit 2 and deeper, zeolites are still present but clays become the dominant alteration mineral. The alteration degree in this interval is variable. Alteration patches, vesicles, and veins (see below) may contain native copper. The first appearance of talc as is observed in Core 36R and coincides with the progressive disappearance of carbonate. From Core 40R to the bottom of the hole, the relative amount of talc increases. However, the general degree of alteration stays low to moderate in these lowest intervals. High alteration degree is observed only in the fault zones corresponding to cataclasites and mylonites in Cores 48R, 49R, 54R, and 55R.

\section{Rock geochemistry}

Seven sediment samples were analyzed from Hole U1442A (1 per core from Cores 352-U1442A-1R through 4R, 7R, 8R, and 10R) for carbonate contents. Carbonate contents range from 50 to 78 wt\%, except for 1 sample (interval 7R-5, 49-50 cm) with $~ 0.6 \mathrm{wt} \%$ carbonate.

We selected 21 representative igneous rock samples from Sections 352-U1442A-11R-1 through 43R-1 to analyze for major and trace element concentrations by ICP-AES. In addition, $\mathrm{H}_{2} \mathrm{O}$ and $\mathrm{CO}_{2}$ concentrations were determined for any samples with LOI $>2$ wt $\%$. The rock surfaces of 167 archive-half pieces were analyzed by pXRF for chemostratigraphic purposes.

The igneous rocks analyzed from Hole U1442A are primarily boninites and their differentiates. The samples have $\mathrm{SiO}_{2}$ contents of 52.5-63.4 wt\%, total alkali $\left(\mathrm{Na}_{2} \mathrm{O}+\mathrm{K}_{2} \mathrm{O}\right)$ contents of 1.44-4.74 wt\%, and $\mathrm{MgO}$ contents of $2.6-17.0 \mathrm{wt} \%$. Primitive magmas from Sites U1439 and U1442 have wide-ranging major and trace element compositions allowing basaltic boninite, low-silica boninite, and high-silica boninite series with different genetic histories to be distinguished. We were able to track the differentiates for each series based on mineral abundances and variations in the concentrations of $\mathrm{SiO}_{2}, \mathrm{MgO}$, and $\mathrm{TiO}_{2}$ (see Preliminary scientific assessment). Site U1442 extends to less high-alkali abundances compared to Site U1439, reflecting the greater degree of alteration in the latter.

\section{Structural geology}

Bedding planes are subhorizontal in the sedimentary units above 75 mbsf, with dips generally $<10^{\circ}$. Between 75 and 155 mbsf, the bedding planes dip $\sim 35^{\circ}$ on average. This change in dip angle defines an angular discordance at $\sim 27-32$ Ma based on biostratigraphic ages. In the igneous units, magmatic structures include contacts between distinct rock types, laminations, flow banding structures, alignments of elongated vesicles, and magmatic breccias. In general, magmatic grains exhibit relatively weak to moderate alignment. Tectonic structures in the basement include shear fractures, cataclastic shear bands, cataclastic shear zones, veins, slickensides, and breccias. Three main fault zones occur at 238.2267.5, 432.8-444.8, and 490.9-502.2 mbsf. The uppermost fault zone comprises fault gouge rich in talc and zeolites, including phillipsite. Slickensides dominantly indicate reverse dip-slip motion, although normal and oblique sense of shear is also observed.

\section{Physical properties}

In the sediments, $P$-wave velocity, magnetic susceptibility, and GRA density values increase across the boundary between lithologic Subunit IIIB and Unit IV at 62 mbsf. This depth corresponds to a strong reflector in the seismic profile across the site. NGR values decrease from the seafloor to the base of Unit IV, with the exception of higher values in Subunit IIIB (clay layer).

In the igneous basement, magnetic susceptibility values are low in igneous Unit 1 (boninite hyaloclastite) and increase abruptly at 260 mbsf near the top of Unit 2 (evolved boninite lavas). NGR values decrease gradually from the top of Unit 1 ( $83 \mathrm{mbsf}$ ) to the base of Unit 4 (523 mbsf). $P$-wave velocities are high and porosities are low in discrete samples taken from $83-170$ and 305-480 mbsf. Thermal conductivity values are relatively constant in Unit 1 and Subunit 2A, increase in Subunit 2B, and decrease in Units 3 and 4.

\section{Paleomagnetism}

Sediment Cores 352-U1442A-2R through 9R were measured with the pass-through cryogenic magnetometer. However a discontinuous record, poor recovery, and drilling-related deformation makes it impossible to interpret the magnetic stratigraphy reliably.

Paleomagnetic samples from the igneous units give paleoinclinations mostly near zero. Low negative inclinations predominate in the upper part of Hole U1442A above 400 mbsf, whereas low positive inclinations are seen below 440 mbsf. These shallow inclinations are consistent with the low paleolatitude of the Izu-Bonin arc at the time of its formation. Transitions between positive and negative inclinations above $400 \mathrm{mbsf}$ are most likely the result of secular variation at low latitudes. The shift to positive inclinations in the lower part of the hole may indicate a magnetic reversal or simply eruption of igneous Units 3 and 4 in a short interval, during which there was little secular variation. Interestingly, the Hole U1439C igneous section shows mainly low positive magnetic inclinations, whereas that of Hole U1442A mostly shows low negative inclinations. This difference may represent a change in magnetic polarity or plate motion between emplacement at the two sites.

\section{Downhole logging}

Hole U1442A was logged with the triple combo-MSS and FMSsonic tool strings. The borehole diameter was within the limits needed for the tools to function properly but the borehole conditions deteriorated during the first tool string deployment, with the hole filling in $>80 \mathrm{~m}$ by the time the second tool string was deployed. Weather conditions and sea state were excellent, with peak- 
to-peak heave $<1 \mathrm{~m}$. Spectral gamma ray values, bulk density, resistivity, magnetic susceptibility, sonic velocity measurements, and microresistivity images were acquired.

Overall, increases in density, resistivity, $P$-wave velocity, and magnetic susceptibility values are observed with depth, whereas spectral gamma ray values decrease. Eight logging units are defined on the basis of distinguishing features and trends in the various logs.

- Logging Unit 1 ( 95-120 mbsf) is characterized by decreasing total gamma ray and velocity values, coupled with increasing resistivity and magnetic susceptibility values downhole.

- Logging Unit 2 ( 120-188 mbsf) is differentiated from the overlying unit by elevated gamma ray and resistivity values and consistently low magnetic susceptibility values.

- Logging Unit 3 ( 188-204 mbsf) displays increased rugosity, which may account for the significant variability across the logging data sets, distinguishing it from the units above and below. - Logging Unit 4 ( 204-232 mbsf) has lower variability in the gamma ray and density logs and magnetic susceptibility values decrease with depth.

- Logging Unit 5 ( 232-258 mbsf)is defined by low magnetic susceptibility punctuated by three significant peaks in combination with high variability in gamma ray values.

- Logging Unit 6 ( 258-282 mbsf) is characterized by decreasing downward trends in both resistivity and density values, which is counter to the overall trend in Hole U1442A.

- Logging Unit 7 ( 282-326 mbsf) shows markedly different character in the gamma ray, density, and resistivity logs compared to the overlying unit.

- Logging Unit 8 (>326 mbsf) does not have full data coverage but is differentiated from Unit 7 by a relatively constant gamma ray profile and a less variable resistivity profile. Oriented microresistivity borehole images indicate a range of textures and structural features, including veins, fractures, and vesicles.

The downhole logging data share similarities with the corresponding core physical properties and geochemical data. However, the logging unit boundaries that are defined on the basis of petrophysical properties do not correlate directly with the petrological boundaries. Postcruise core-log interpretation will focus on fully integrating the downhole and core data sets.

\section{Preliminary scientific assessment}

Expedition 352 successfully cored $\sim 1.22 \mathrm{~km}$ of igneous basement created immediately following subduction initiation in the Bonin fore arc, together with $461 \mathrm{~m}$ of overlying sediment (Table T2). The original plan was to drill two sites to $750 \mathrm{mbsf}$ each. Drilling conditions limited depths of penetration at the first two sites and, if the original planned casing strategy had been used, little time

Table T2. Sediment and basement cored intervals, Expedition 352. Download table in .csv format.

\begin{tabular}{ccc}
\hline Hole & $\begin{array}{c}\text { Sediment } \\
\text { (mbsf) }\end{array}$ & $\begin{array}{c}\text { Basement } \\
\text { (mbsf) }\end{array}$ \\
\hline U1439A & $0-178.5$ & $178.5-199.4$ \\
U1439C & - & $182.0-544.3$ \\
U1440A & $0-103.5$ & $103.5-106.1$ \\
U1440B & $102.3-115.3$ & $115.3-383.6$ \\
U1441A & $0-83.0$ & $83.0-205.7$ \\
U1442A & $0-83.1$ & $83.1-529.8$ \\
\cline { 2 - 3 } Total $(\mathrm{m}):$ & 461.1 & 1223.5 \\
\hline
\end{tabular}

would have been left for additional drilling at alternative sites. The decision to drill in the casing at both original sites saved $\sim 10$ days, which provided the time for drilling two additional sites (U1441 and U1442). This marks only the second time a casing string was drilled in since ODP Leg 196 and the first time a complete reentry system was deployed this way.

The basement core provides diverse, stratigraphically controlled suites of lavas and shallow intrusive equivalents of our target rock types: FAB and boninite related to seafloor spreading and earliest arc development. FAB was recovered at the two deeper sites (U1440 and U1441) and boninites at the two shallower sites (U1439 and U1442). Although recovery averaged $\sim 21 \%$ for the igneous sections drilled (see Principal results for details), this recovery was sufficient to provide an excellent suite of samples for documenting the petrology, geochemistry, volcanology, and structure of the four basement sites. Onboard observations and data collection have already produced a significantly clearer understanding of both the development of the crustal architecture of the Bonin fore arc and the variations in sources and melting mechanisms through time for this region. The sediment core provides a record of the depth-time evolution of the fore-arc basement following subduction initiation and, through study of the interspersed ash layers, contributes to our understanding of the overall volcanic evolution of the region.

The overarching goal of Expedition 352 was to characterize the volcanic products of subduction initiation and early arc development and to use the results to understand better the subduction initiation process and its relevance to on-land geology. The objectives related to this goal and stated in the Expedition 352 Scientific Prospectus are listed below, accompanied by our assessment about how these objectives were addressed and the resulting discoveries. We conclude with a statement listing discoveries that went beyond those directly addressing the original objectives.

\section{Obtain a high-fidelity record of magmatic evolution during sub- duction initiation by coring volcanic rocks down to underlying in- trusive rocks, including radiometric and biostratigraphic ages.}

One major achievement of Expedition 352 was the recovery of 4 lava sequences that provide evidence for the temporal evolution of volcanic activity during the nascent development of the IBM volcanic arc. These sequences cluster into two groups (Figure F19). The first group (Sites U1440 and U1441) addressed the chemostratigraphy and petrological evolution of $\mathrm{FAB}$, and the second group (Sites U1439 and U1442) did the same for boninite-series igneous rocks. Defining the petrological/geochemical units and formulating ideas about sources and melting processes needed to generate these lavas onboard the ship was made possible by the analysis of cut rock surfaces using a Thermal Niton pXRF instrument. Expedition 352 is the first instance in which pXRF measurements have been successfully used to distinguish rock units chemically while core is being described. These real-time data also proved useful in targeting intervals for shipboard ICP-AES analyses on cores as they were recovered. The collaboration between the shipboard geochemists and petrologists emphasizes the importance of close coordination between different areas of expertise during core description and analysis, here resulting in the establishment of a new tool for use during basement coring. The targeted ICP-AES data collected onboard allowed us to generally classify the rocks based on major element data and provided important additional trace elements.

The formal naming of the volcanic rocks was carried out using modified IUGS protocols based on the three major element oxides, $\mathrm{TiO}_{2}, \mathrm{SiO}_{2}$, and $\mathrm{MgO}$. This allowed us to identify parental boninites 
Figure F19. Schematic igneous stratigraphic columns for Expedition 352 drill sites, from west to east. The western sites, U1439 and U1442, consist of boninite group lavas, including HSB, LSB, basaltic boninites, and evolved boninite-series lavas. Site U1442 includes a thick section of volcaniclastics and consists largely of hyaloclastite breccias with intercalated lava flows. In contrast, Site U1439 comprises lava flows with fewer hyaloclastite horizons. At both boninite sites, the most depleted primary boninites are found at the top of each section. The eastern sites, U1441 and U1440, consist of fore-arc basalts, including lavas, dikes or sills, and a transition zone of lavas and dikes. D-FAB, an ultradepleted variety of FAB with exceptionally low Ti concentrations, was found at Site U1441.
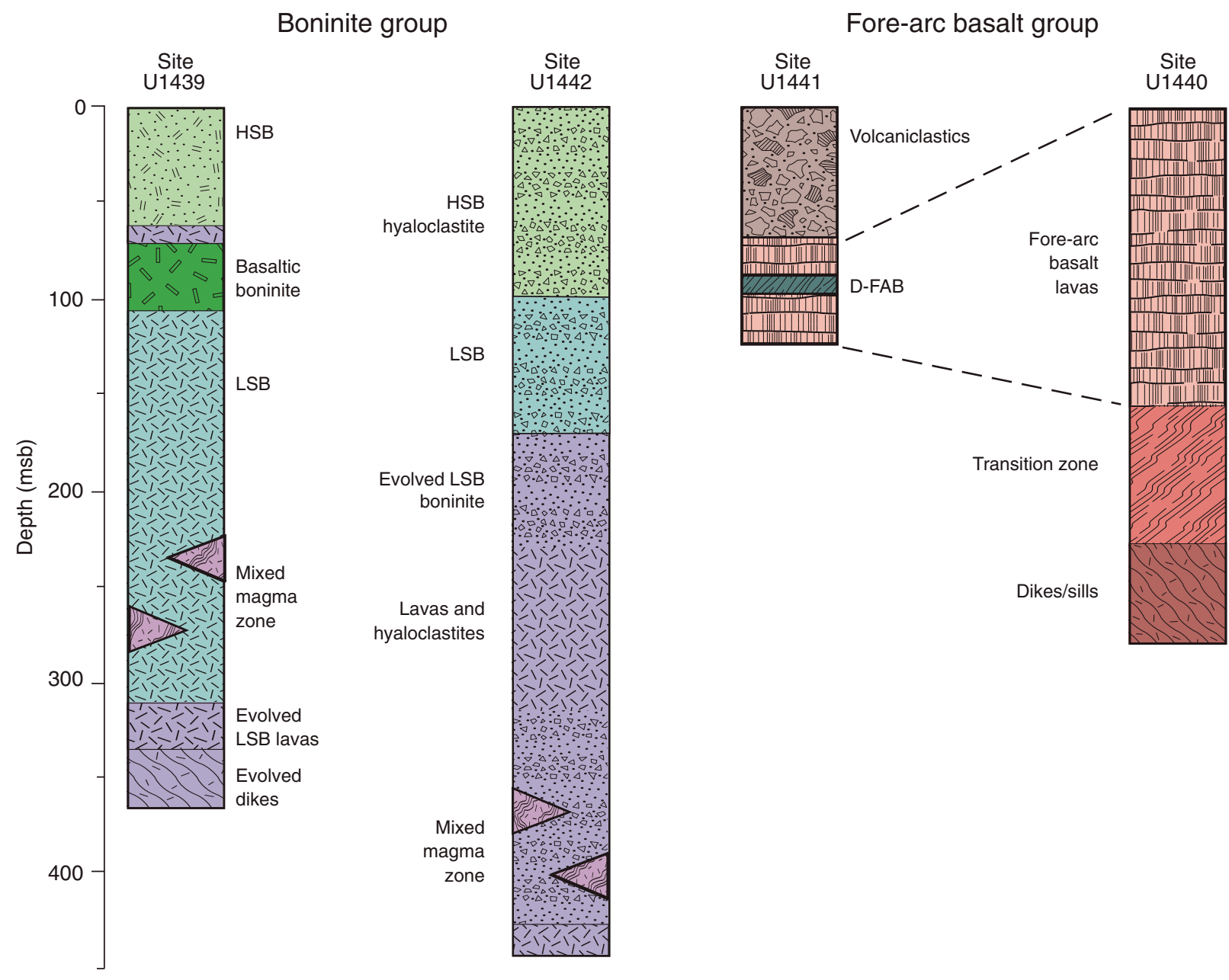

based on the IUGS criteria (Le Bas, 2000) of $<0.5 \mathrm{wt} \% \mathrm{TiO}_{2},>52 \mathrm{wt} \%$ $\mathrm{SiO}_{2}$, and $>8 \mathrm{wt} \% \mathrm{MgO}$ (Figure F20). Criteria based on those in Pearce and Robinson (2010) were used to extend the classification of parental magmas to boninite series. As Figure F20 shows and as is documented in the individual site chapters, these two diagrams provide the basis for the conclusion that the deeper sites (U1440 and U1441) predominantly recovered tholeiitic (FAB) lavas and dikes, whereas the shallower sites (U1439 and U1442) predominantly recovered boninitic lavas and dikes.

In addition, lava compositions varied enough in the boninites to compel division into three series. We defined a basaltic boninite series to include lower $\mathrm{SiO}_{2}$ concentrations for parental magmas than those allowed by the IUGS classification. The boninite field on the $\mathrm{MgO}$ versus $\mathrm{SiO}_{2}$ diagram itself was divided into low-silica and high-silica boninite series following the concept of Kanayama et al. (2013). This subclassification reveals some important variations. Most importantly, relatively primitive high-silica boninites form the upper units of both boninite holes. Another significant finding is the abundance of evolved members of the boninite series (highmagnesium andesites) in igneous Unit 2 of Hole U1442A and at the

base of the lava sequence in Hole U1439C. Only one series was made for the FAB rocks based on their uniformly basaltic parent magma compositions. Nevertheless, $\mathrm{FAB}$ lavas have ranges in $\mathrm{TiO}_{2}$ concentrations that require significant variations in parental magma compositions. For example, several rocks plot as basalt in the $\mathrm{MgO}$ versus $\mathrm{SiO}_{2}$ diagram but on the boninite/basalt boundary of the $\mathrm{TiO}_{2}$ versus $\mathrm{SiO}_{2}$ diagram. We termed these lavas D-FAB (D for depleted), to our knowledge the first lavas of this composition to be recovered from in situ oceanic crust.

Note that only ICP-AES data can be classified in this way because $\mathrm{SiO}_{2}$ and $\mathrm{MgO}$ could not be analyzed by pXRF. Moreover, $\mathrm{SiO}_{2}$ is significantly dependent on alteration. As a result we developed proxy diagrams ( $\mathrm{Ti}$ versus $\mathrm{Cr}$ and $\mathrm{Ti} / \mathrm{Zr}$ versus $\mathrm{Cr}$ ) that can informally classify the whole core even for relatively highly altered samples or for those not chosen for ICP-AES analysis (see Petrology in the Expedition 352 methods chapter [Reagan et al., 2015]). The classifications confirm those made by Figure F20 and have enabled each unit from each core to be classified in terms of magma type, as shown in the stratigraphic summary of Figure F19. 
Figure $\mathrm{F} 2 \mathrm{O} . \mathrm{MgO}$ vs. $\mathrm{SiO}_{2}$ and $\mathrm{TiO}_{2}$ vs. $\mathrm{MgO}$ diagrams used to classify the volcanic rocks and dikes sampled during Expedition 352. Boninites (sensu stricto) are defined by IUGS (Le Bas, 2000) as having MgO $>8 \mathrm{wt} \%, \mathrm{TiO}_{2}<0.5$ $\mathrm{wt} \%$, and $\mathrm{SiO}_{2}>52 \mathrm{wt} \%$ and so plot in the shaded rectangular fields on both diagrams. The dividing line between the boninite and the basalt-andesitedacite-rhyolite (BADR) series is from Pearce and Robinson (2010) (Trans. = transitional). The upper boninite series field has been divided by us into basaltic, low-silica, and high-silica boninites for more precise naming of recovered rocks. Evolved boninite series rocks classify as HMA and plot in the fields shown.
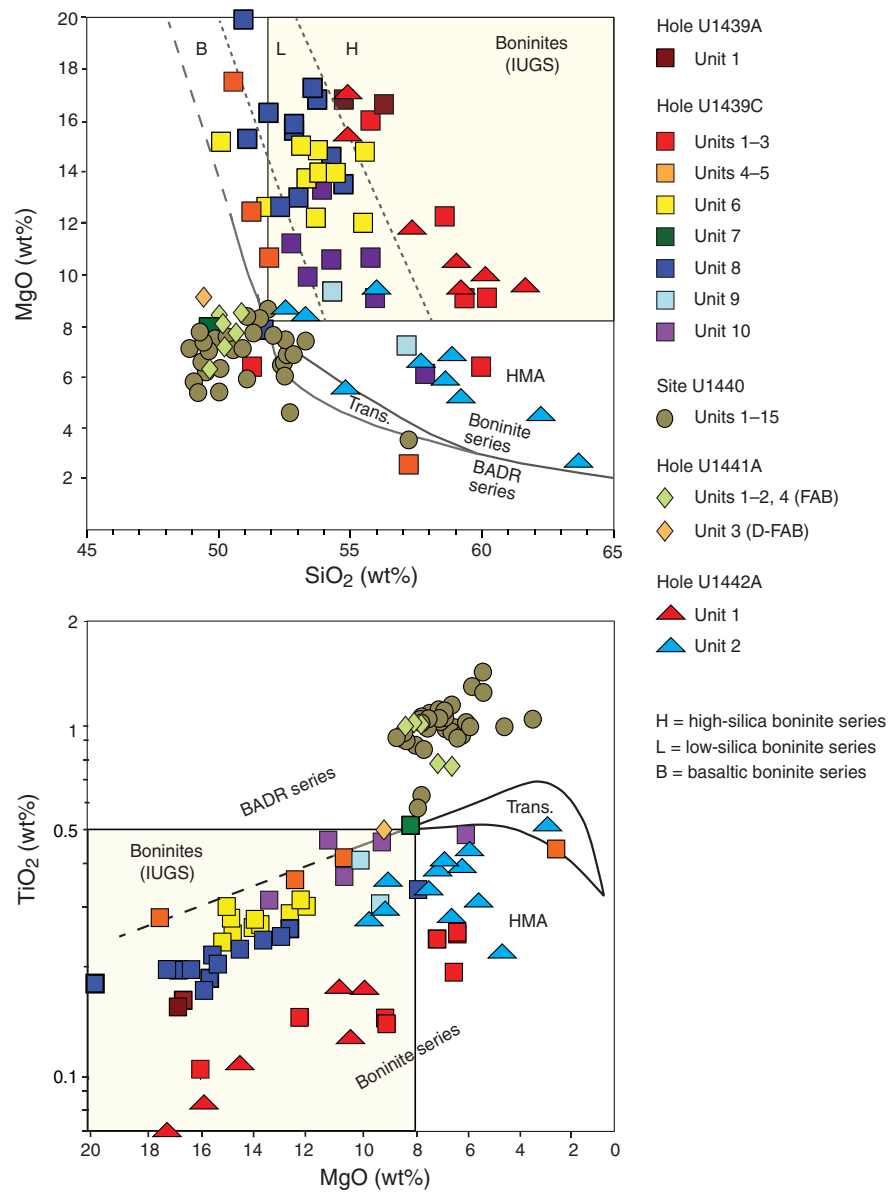

\section{FAB Sites U1440 and U1441}

The chemical compositions and mineral abundances of the lavas and dikes cored at Sites U1440 and U1441 are similar to each other. They are also similar to FAB collected during the nearby submersible dives (see Ishizuka et al., 2011) and during sampling of the Mariana fore arc to the south (Reagan et al., 2010). Lavas from Hole $\mathrm{U} 1440 \mathrm{~B}$ are underlain by a transition zone and then $40 \mathrm{~m}$ of what appears to be a sheeted dike complex, which we take to indicate that we drilled the entire extant FAB lava sequence. In contrast, Hole U1441A had significantly less penetration, was capped by a talus deposit, and did not intersect intrusive rocks. Therefore, Hole U1440B has the best reference section for illustrating the chemostratigraphy of the FAB sites.

FAB lavas and dikes from Sites U1440 and U1441 are seen in Figure F20 to be tholeiitic rather than boninitic, and the total alkalisilica (TAS) plot of LeBas et al. (1986) shows them to be predominantly basalts. Exceptions are a few basaltic andesites with 52$53 \mathrm{wt} \%$ silica and the highly differentiated andesite that makes up
Figure F21. (A) Zrvs. $\mathrm{TiO}_{2}$ (B) $\mathrm{Sr} / \mathrm{Ti}$ vs. $\mathrm{Ti} / \mathrm{Zr}$, and (C) V vs. $\mathrm{TiO}_{2}$ for Sites U1439U1442 and selected cores from DSDP Site 458. Diagonal lines in A illustrate $\mathrm{Ti} / \mathrm{Zr}$ ratios, and those in $\mathrm{C}$ represent $\mathrm{Ti} / \mathrm{N}$ ratios. The yellow fields illustrate Pacific and Atlantic MORB compositions using the glass analyses of Jenner and O'Neill (2012).
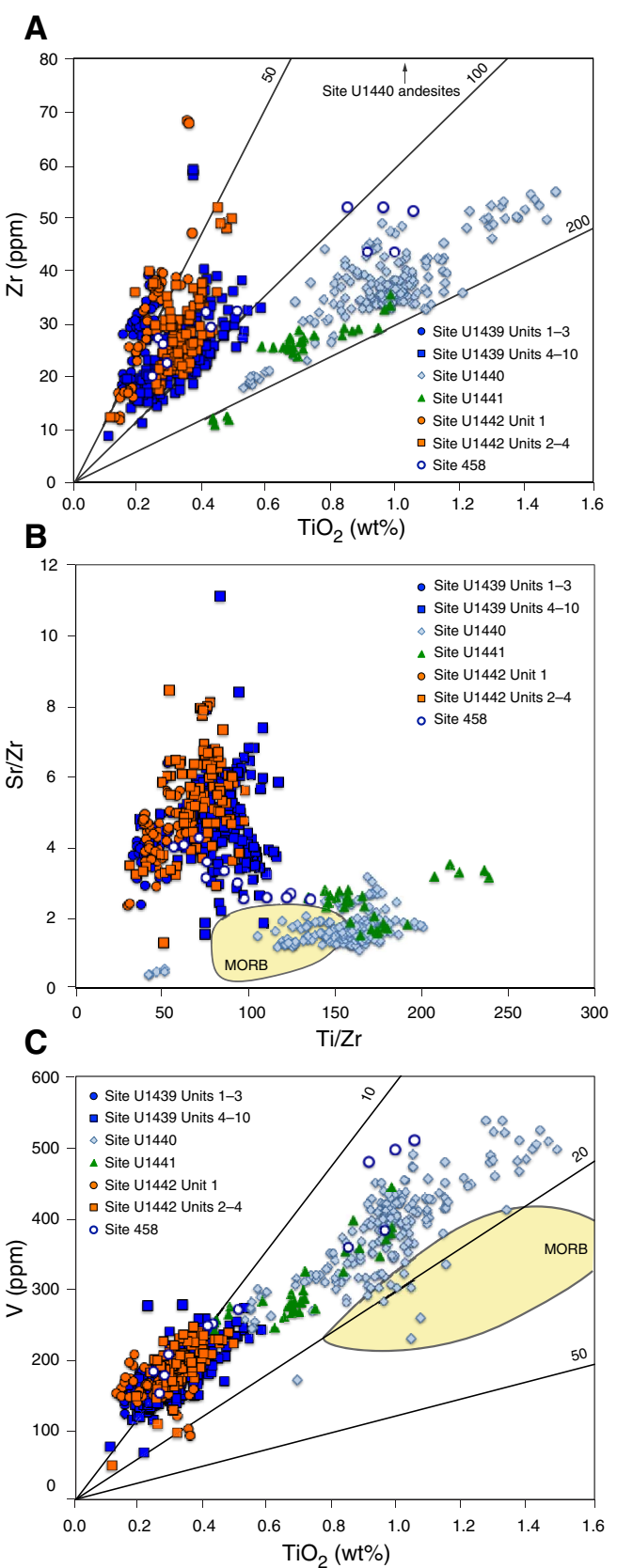

igneous Unit 6 at Site U1440 (see Site U1440 summary). With the exception of the Unit 6 andesites, FAB from our sites and other IBM fore-arc locations is characterized by low $\mathrm{Ti} / \mathrm{Zr}$ ratios and low abundances of both elements relative to MORB (Figure F21), demonstrating that they are generated by higher degrees of melting or from a more depleted mantle than for lavas from mid-ocean ridges.

The concentrations of trace elements and $\mathrm{CaO}$ in $\mathrm{FAB}$ lavas are relatively diverse because of variations in parental melt compositions in degree of differentiation and degree of alteration. Below the heterolithic breccia making up Unit 1 at Site U1441 and especially beneath Unit 4 in Hole U1440B, Cr and Mg concentrations gener- 
Figure F22. Concentrations of $\mathrm{TiO}_{2}$ and $\mathrm{Cr}$ with depth, Hole U1440B.
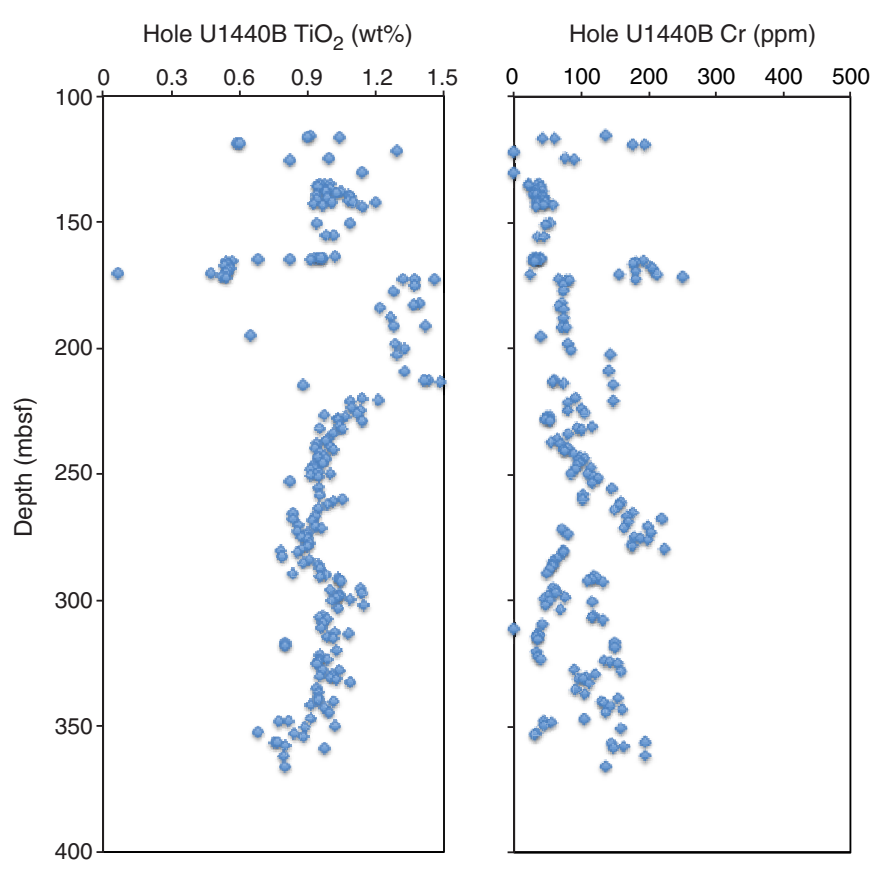

ally increase with depth (Figures F22, F23), indicating an increase in the degree of differentiation upward. Nevertheless, these trends have significant overall fine-scale diversity and are punctuated by narrow sections of core with significantly more, or less, differentiated lavas. The andesites from Site U1440 Unit 6 mentioned above represent one such significant compositional excursion. These lavas have the lowest $\mathrm{Ti} / \mathrm{Zr}$ and $\mathrm{Sr} / \mathrm{Zr}$ values (Figure F21) of any of the FAB-related lavas. We attribute this to extensive plagioclase and titanomagnetite fractionation, perhaps in a small, isolated, and shallow magma reservoir. Other compositional excursions are represented by the high-Cr, and hence less fractionated, lavas in the two cores that make up Unit 3 in Hole U1440B and the D-FAB from Hole U1441A.

Superimposed on these magma chamber effects are variations in incompatible trace element ratios that represent variations in source compositions. Two units from Hole U1440B (Units 4 and 8) and some basal dolerite dikes have $\mathrm{Sr} / \mathrm{Zr}$ ratios similar to those of average N-MORB ( 1.25), indicative of mantle sources with little or no subducted material. Other units have relatively elevated $\mathrm{Sr} / \mathrm{Zr}$, but most are still within the range of MORB glasses taken from the laser-ablation inductively coupled plasma-mass spectrometry data set of Jenner and O'Neill (2012) (Figure F21), suggesting that any subduction influence was small, at least in terms of $\mathrm{Sr}$ input, throughout the genesis of most lavas from this site. A small set of samples do, however, plot clearly above the field of MORB glasses. This includes the aforementioned D-FAB samples from Hole U1441A, where the ultradepleted source may have made the subduction component more evident. Sr is, of course, mobile during alteration. Nevertheless, the consistency of $\mathrm{Sr} / \mathrm{Zr}$ within most units likely reflects interbedding of lavas derived from mantle sources with different subduction inputs. The D-FAB unit, as noted above, has exceedingly low incompatible trace element abundances, the highest $\mathrm{Ti} / \mathrm{Zr}$ (Figure F21), and the highest $\mathrm{CaO}$ concentrations of any uncalcified lava collected during the expedition. This lava was generated by the highest degree of melting, or from the most de-
Figure F23. Concentrations of $\mathrm{TiO}_{2}$ and $\mathrm{Cr}$ with depth, Hole U1441A.

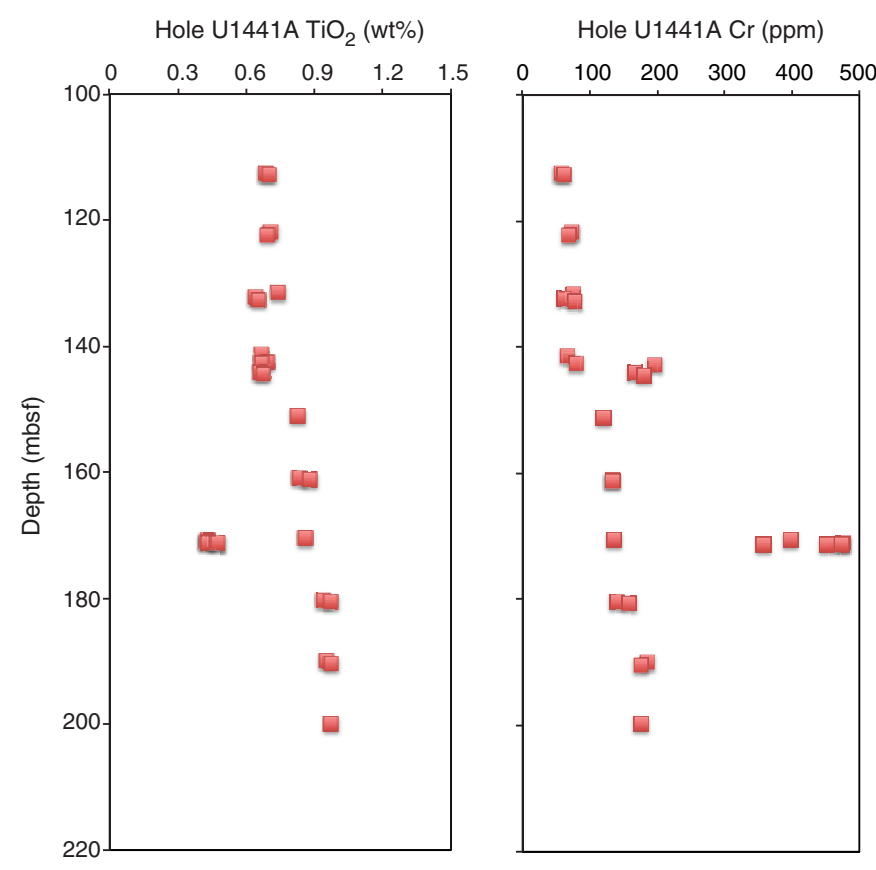

pleted source, of all FAB, and we tentatively interpret its high $\mathrm{Ti} / \mathrm{Zr}$ and high $\mathrm{CaO}$ to reflect melting of its mantle source to near the point of clinopyroxene exhaustion.

\section{Boninite Sites U1439 and U1442}

The compositions of boninite group lavas drilled at Sites U1439 and U1442 are chemically distinct from FAB. In contrast to FAB Sites U1440 and U1441, lavas in both of the boninite sites have compositions that become more primitive upward. Irrespective of degree of differentiation, $\mathrm{TiO}_{2}$ concentrations generally decrease and $\mathrm{SiO}_{2}$ concentrations generally increase upward in lavas from both boninite sites. Based on these compositional variations, the lowermost lavas are classified as basaltic boninites and low-silica boninites and the capping lavas as high-silica boninites resembling those that form the base of the lava sequence at Chichijima. Nevertheless, differences in the thicknesses of chemostratigraphic units are surprisingly great considering that the sites were only $\sim 1.3 \mathrm{~km}$ apart (Figure F24).

Our best geochemical correlation between the stratigraphic records at the two sites places differentiated basaltic boninite to lowsilica boninite series lavas at the base of both sites. The uniformly low $\mathrm{Cr}$ and $\mathrm{MgO}$ concentrations in these lavas suggest they represent magmas that fractionated in a magma chamber that persisted during the eruption of this unit. The thickness of this basal sequence appears to change from $\sim 20$ to $\sim 200 \mathrm{~m}$ from Site U1439 (Unit 9) east to Site U1442 (Units 2-4). Overlying the basal sequence at both sites are lavas of the low-silica boninite series that change in thickness from $\sim 230 \mathrm{~m}$ at Site U1439 to $80 \mathrm{~m}$ at Site U1442. These lavas have higher and more variable Ti/Zr ratios than the underlying lavas (Figure F21), indicating that they were tapped from variably depleted mantle by variably high degrees of melting.

Note, however, that paleomagnetic results collected on board are not entirely consistent with the stratigraphic correlations based on geochemistry. The average paleomagnetic inclination in Hole $\mathrm{U} 1439 \mathrm{C}$ is positive by $\sim 5^{\circ}$, whereas the equivalent average in Hole 
Figure F24. $\mathrm{Cr}$ concentrations and $\mathrm{Ti} / \mathrm{Zr}$ ratios with depth. The central colored bars represent our stratigraphic correlation between these two holes (see text for further explanation). $\mathrm{BB}=$ basaltic boninite.
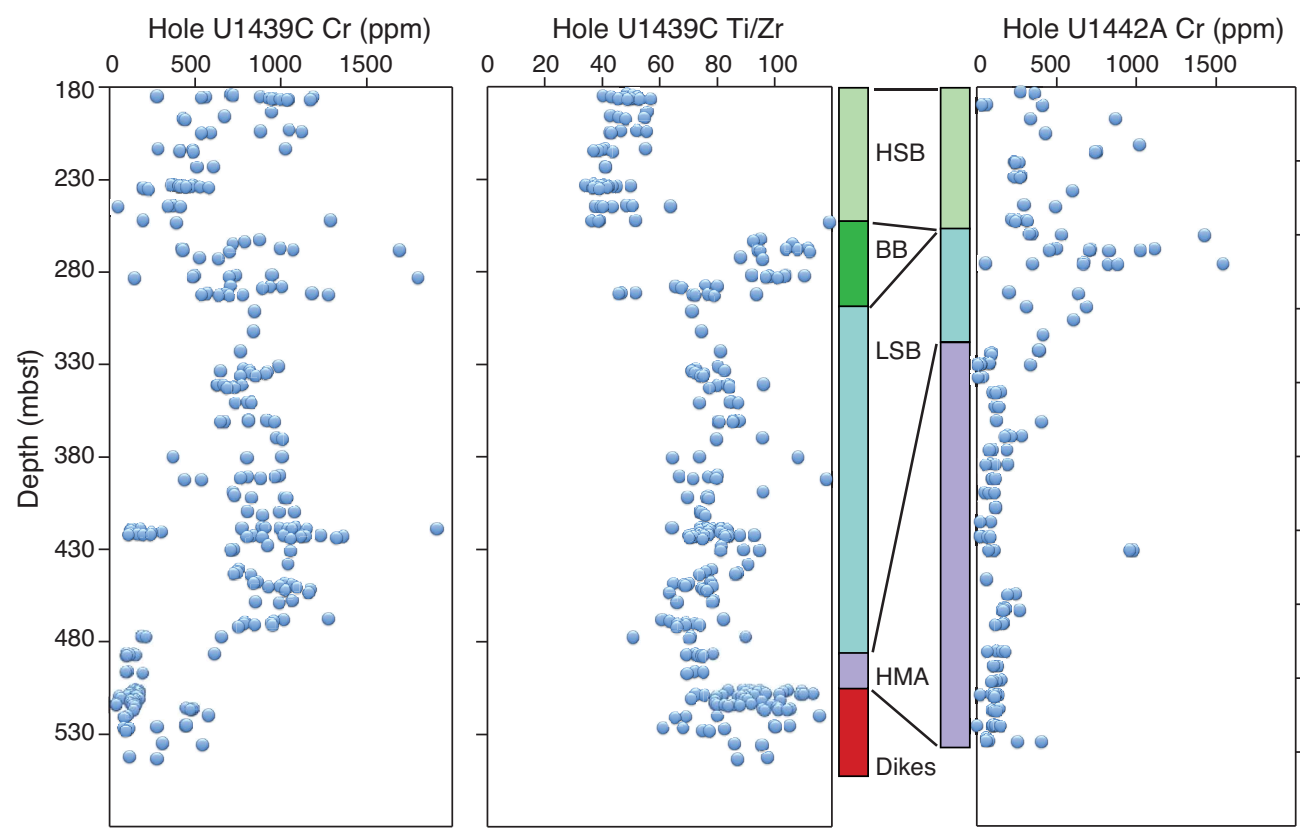

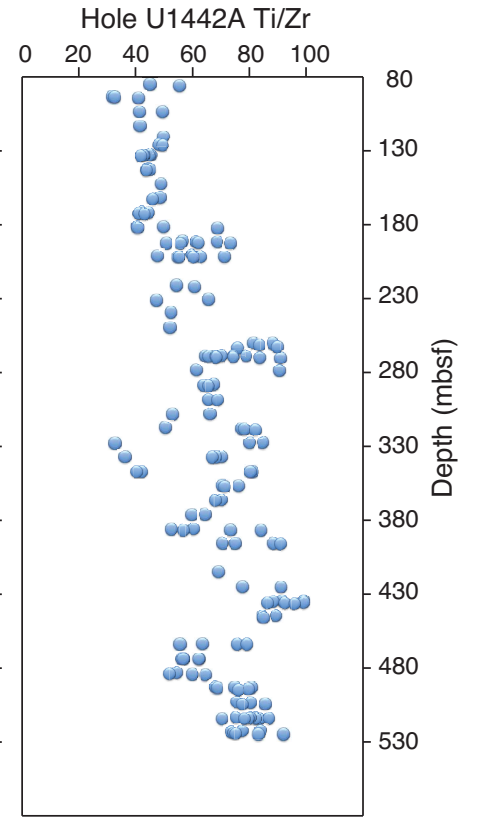

$\mathrm{U} 1442 \mathrm{~A}$ is a few degrees negative, which implies that the ages of volcanism at the two holes are separated by a magnetic reversal or Philippine plate motion. However, the inclination data collected shipboard are unequally distributed, and the variations could simply reflect a sampling bias. The majority of the negative inclinations in Hole U1442A are in high-silica boninite from Unit 1, whereas the inclination measurements in the equivalent units in Hole U1439C (Units 1-4) are too sparse to distinguish them statistically. A similar case can be made for the low-silica boninite, where Units 6-9 in Hole U1439C have more than three times as many measurements compared to Units 2-4 in Hole U1442A. Clearly, postcruise investigations of geochemistry, geochronology, and paleomagnetism will be needed to robustly correlate the stratigraphy between the two boninite sites.

Mingling between magmas with high and low $\mathrm{Cr}$ concentrations is common in this unit. This demonstrates that some magmas ponded for long enough in the crust to undergo significant crystal fractionation and erupt, whereas others rose to the surface essentially unfractionated, and that these two magmas commonly mingled and erupted before significant mixing could occur. Unit 5 in Hole U1439C represents a compositional excursion to basaltic boniniteseries lavas. These lavas differ from equivalent series lavas from deeper in this hole in that they have relatively high $\mathrm{Cr}$ concentrations in keeping with the more primitive compositions of lavas from adjacent depths in this hole. The high-silica boninites atop both holes have similar compositions. Although a few significantly differentiated lavas are present in these upper boninites, most are relatively primitive with $\mathrm{Cr}$ concentrations of $200-1600 \mathrm{ppm}$ and $\mathrm{MgO}$ of 9-17 wt\%. The extreme depletion of the mantle sources and degrees of melting for these lavas is reflected in the low $\mathrm{TiO}_{2}$ concentrations, which are typically $<0.3 \mathrm{wt} \%$, and in low $\mathrm{Ti} / \mathrm{Zr}$ ratios, which are $<60$.

Although coring in Hole U1442A ended in boninite-group lavas, Hole U1439C drilled $\sim 50 \mathrm{~m}$ into a sequence of dolerites, with compositions spanning the range of $\mathrm{Ti} / \mathrm{Zr}$ ratios of overlying lavas but with overall lower $\mathrm{Cr}$ concentrations. Our inference is that geneti- cally related dikes underlie the boninitic-group lavas. We found no evidence for the presence of FAB resembling those drilled at Sites U1440 and U1441 beneath the boninite-group lavas.

\section{DSDP Sites 458 and 459}

Selected archive cores from Mariana fore arc Site 458 were onboard the JOIDES Resolution for training purposes during Expedition 352 . We used this opportunity to analyze these cores using the pXRF instrument so that their compositions could be directly compared with those from our drill sites. The results show that the rocks from DSDP Site 458 are generally more differentiated than those drilled at Sites U1439 and U1442, with Cr concentrations ranging from $275 \mathrm{ppm}$ to below detection limits. Site 458 Cores 28 , 39 , and 43 have $\mathrm{TiO}_{2}$ and $\mathrm{Zr}$ concentrations resembling those of the low-silica boninites from the lower to middle sections of Holes U1439C and U1442A, whereas Core 47 has compositions similar to the andesite from Hole U1440A (Figure F21). The original geochemical data for DSDP sites (Wood et al., 1982; Meijer et al., 1982) demonstrate that Cores 43-45 from Site 458 and Cores 60-64 from Site 459 have compositions that are intermediate between those of our FAB and boninite sites. Our $\mathrm{Cr}$ and $\mathrm{MgO}$ concentrations and those published in Wood et al. (1982) indicate that the Site 458 and 459 lavas are typically highly fractionated. This further supports the existence of a magma chamber during the eruption of these transitional lavas.

\section{Use the results of Objective 1 to test the hypothesis that fore-arc basalt lies beneath boninites and to understand chemical gradi- ents within these units and across their transitions.}

We expected FAB to be present at the base of the Bonin fore-arc volcanic succession and a sequence of boninite-series lavas to be present atop these FAB. Our pre-expedition drilling strategy, in fact, was to drill a single section from boninite through to FAB dikes. We did not, however, encounter this stratigraphy at any of the drill sites. Instead, the presence of dikes at the base of the sections at Sites U1439 and U1440 provides evidence that these lavas are underlain 
by their own conduit systems and that FAB and boninite group lavas are likely offset more horizontally than vertically.

The separation of compositions for the $\mathrm{FAB}$ and boninite sites is best seen on the plot of $\mathrm{Zr}$ versus $\mathrm{TiO}_{2}$ concentrations (Figure F21). On this plot, the trenchward FAB sites (U1440 and U1441) have high $\mathrm{Ti} / \mathrm{Zr}$ ratios that completely separate them from the low $\mathrm{Ti} / \mathrm{Zr}$ ratios, and low absolute values of $\mathrm{Ti}$ and $\mathrm{Zr}$, of the boninite sites (U1439 and U1442). This gap appears to be filled by the compositions of lavas from Sites 458 and 459, providing some evidence that we drilled the two end-members of a FAB-boninite spectrum, but there is a continuity of compositions within which transitional members do exist. The implication is that FAB erupted closer to the trench than boninite, and we speculate that lavas of transitional compositions may have erupted at an intermediate distance from the trench.

\section{Use drilling results to understand how mantle melting processes evolve during and after subduction initiation.}

The results summarized in the assessment of Objective 2 are best explained by temporal evolution, not just of the mantle melting process itself, but also of location of that melting and of the nature of the plumbing system taking the melts from the mantle to the surface. Although the compositions of FAB lavas erupted at Sites U1440 and U1441 apparently vary through time in terms of the amount of slab fluid involved in their genesis and their extent of differentiation, all are relatively evolved, with most $\mathrm{Mg}$ concentrations lying within the range $5-8 \mathrm{wt} \%$. These lavas could have been fed from magma chambers that persisted throughout the eruptive history of FAB.

In the boninitic section, the lowermost lavas at Sites U1439 and U1442 also are relatively differentiated, with a thickness that increases to the east (i.e., from Site U1439 to U1442). Stratigraphically higher lavas at both sites are both differentiated and primitive in composition, with mingling common between the two. Primitive high-silica lavas derived from the most depleted mantle cap the stratigraphy at both sites. The changes in composition support a model in which a persistent magma chamber system was present early during genesis of boninite group lavas, especially at the more easterly boninite Site U1442. This persistent chamber system disappeared by the time high-silica boninites erupted at both sites. If the lower boninites formed at a ridge axis, these high-silica boninites could represent off-axis magmatism, perhaps the start of a protoarc.

As noted above, the $\mathrm{Sr} / \mathrm{Zr}$ ratios overlap with those for MORB for all but a small set of FAB lavas. The latter include the most depleted, where the subduction component is most visible. In addition, the drilled FAB (Figure F21), as well as those previously sampled from the IBM region (Figure F4), plot in the island arc field on a V-Ti plot. These observations support a small subduction contribution to the genesis of at some FAB lavas and dikes, likely reflecting water-enhanced melting resulting in higher oxygen fugacity and a greater degree of melting than is normally prevalent at midocean ridges (Shervais, 1982).

Boninites all were generated after the addition of a more significant flux of water-rich fluid, and perhaps a melt, from the subducting slab. The degree of depletion of $\mathrm{TiO}_{2}$ (Figure F21), as well as $\mathrm{CaO}$, increases upsection, implying that the overall depletion of the mantle continues from the FAB group through into the boninite group lavas.

These results indicate that seafloor spreading related to subduction initiation and eruption of FAB, having begun at $\sim 52 \mathrm{Ma}$
(Ishizuka et al., 2011; Reagan et al., 2013), also migrated from east to west. We believe, on the basis of the consistently evolved lower lavas and dikes, that spreading was rapid and, like fast-spreading centers (e.g., the East Pacific Rise; Langmuir et al., 1986), an axial magma chamber was present. Melting was largely decompressional during this period, but subducted fluids significantly affected at least some of the melting. Relatively fast spreading continued migrating to the west of the subduction zone through the eruption of the differentiated basaltic boninites. One plausible hypothesis is that the spreading rate had by that time declined such that a persistent magma chamber could no longer be maintained, allowing progressively more primitive lavas to erupt (cf. slow-spreading ocean ridges, Dick, 1989; Langmuir et al., 1992). The high-silica boninite at the top of the lava sequence might then represent the final magmatic phase of such a ridge when most erupting lavas were primitive. Alternatively, the high-silica boninites could represent off-axis eruptions resulting from continued melting of depleted mantle trenchward of the westward migrating ridge axis.

The initial extreme depletion of the sources for all boninite group lavas was likely related to FAB generation. This depletion likely resulted in melting of harzburgite by the time the high-silica boninites were generated. Melting of such mantle to the point of clinopyroxene exhaustion could have been achieved by a strong influx of a subduction component from the subducting plate.

\section{Test the hypothesis that the fore-arc lithosphere created during subduction initiation is the birthplace of suprasubduction zone ophiolites.}

By recovering the first sections of in situ subduction initiation oceanic crust, Expedition 352 successfully demonstrated that forearc lithosphere created during subduction initiation could be a potential birthplace of suprasubduction zone ophiolites. This was another major achievement of this expedition.

Specifically, Expedition 352 drilled the end-members of the suprasubduction zone ophiolitic spectrum: oceanic lithosphere created from FAB magma (Sites U1440 and U1441) and oceanic lithosphere created from boninite magma (Sites U1439 and U1442). Although we do not have the complete crustal sections, the fact that two sites rooted in dikes following penetration of oceanic volcanic rocks is consistent with such an interpretation. Moreover the recovery of gabbros and peridotites by dredging and submersible from the deeper parts of the fore arc supports the likelihood of an overall ophiolitic structure.

The relative ages of the two sets of sites is critical for any interpretation and will be an important part of the follow-up work. Although they have not yet been dated, comparable rocks recovered from the fore arc prior to the expedition leads us to expect that the age of the FAB section lies between 51 and $52 \mathrm{Ma}$ (Ishizuka et al., 2011; Reagan et al., 2013), whereas the age of the boninite section is somewhat younger (low-silica boninite from Site 458 is $\sim 9 \mathrm{Ma}$, the oldest high-silica boninite from Chichijima is $48 \mathrm{Ma}$; Cosca et al., 1998; Ishizuka et al., 2006).

There are ophiolites that have full lava sequences based on only one magma type and, for these, the Expedition 352 sites could provide good analog sections. Some well-preserved examples of ophiolitic upper crust derived entirely from FAB magma include the Western Mirdita complex (Dilek et al., 2008) and the Coto Block of the Zambales ophiolite (Yumul, 1996), which only have FAB lavas (using FAB in the broadest sense of any tholeiitic basalt formed by spreading and located in a fore-arc setting). Examples of ophiolitic crust derived entirely from boninitic magma include Betts Cove in 
Newfoundland (Bédard et al., 1998) and the Acoje Block of the Zambales ophiolite (Yumul, 1996). In their study of Betts Cove, Bédard et al. (1998) inferred that this entirely boninitic ophiolite formed in a fore-arc setting, a conclusion supported by the core from Sites U1439 and U1442.

However, we are aware that the sequence of events in which fore-arc basalts are overlain by boninites is also common in many ophiolites. Well-documented examples include the Troodos, Oman, Eastern Mirdita, and the Pindos/Vourinos ophiolites (see review by Dilek and Flower, 2003). Here, volcanic rocks of FAB compositions (again, in broad sense) are overlain by lavas, or intruded by dikes, of boninitic composition. Compositionally composite sequences such as these are not comparable with our drilled sections, although the magmatic sequence of FAB followed by boninite in these ophiolites is consistent with our inference that FAB magmas predated boninite magmas in the Bonin fore arc. It is possible, indeed likely, that such composite lithosphere is located between our two sets of sites, where there was insufficient sediment for us to drill. However, we are fortunate that deep-sea drilling in the Mariana fore arc (at Sites 458 and 459) did recover lavas of both boninite and FAB composition, as well as lavas transitional between the two, within the same drilled section.

Thus, between our Bonin fore-arc drill sections and those of DSDP in the Mariana fore arc, we usefully cover much of the compositional spectrum of the world's SSZ ophiolites. We note that the IBM fore arc may not be an exact analog for all SSZ ophiolites. Nevertheless, the general concept of increasing mantle depletion and subduction flux in a highly extensional subduction initiation setting could be a viable general model for their evolution.

\section{Additional results}

\section{Sedimentology and biostratigraphy}

Eocene to recent deep-sea sediment was recovered from above the Izu-Bonin fore-arc basalts and boninites (the upper part of a putative SSZ ophiolite complex). The sedimentary record provides an excellent reference for modern and ancient sedimentation in an intermediate-latitude, intraoceanic fore-arc setting. Three of the drill sites (Sites U1439-U1441) are located in fault-controlled sediment ponds up to several hundred meters thick, whereas one site (U1442) was positioned on thin sediment overlying a fault-controlled basement high (Figure F25).

The overall sediment sequence reflects the interplay of five main types of control:

1. Local basement erosion and redeposition (e.g., altered extrusive igneous rocks),

2. Regionally controlled volcanism (arc or back arc),

3. Paleoceanography (e.g., calcite compensation depth and currents),

4. Eolian input (widely dispersed ash and/or Asia-derived continental dust), and

5. Diagenesis (e.g., carbonate, zeolite, and manganese).

The basal sediment, typically overlying a manganese crust (Eocene-Oligocene), is pelagic carbonate mixed with detritus that was eroded from underlying, variably altered igneous crust. Above the basement, pelagic carbonate predominates in the Oligocene to earliest Miocene and also in the late Pliocene to Pleistocene. In contrast, relatively noncalcareous, radiolarian-rich silty clays dominated during the early Miocene. In addition, volcaniclastic sediment is relatively abundant during the early Oligocene to Eocene and also in the middle Miocene to lower Pliocene.

Three phases of highly explosive volcanism (latest Pliocene to Pleistocene, late Miocene to earliest Pliocene, and Oligocene) are represented by 132 graded air fall tephra layers, which are likely to be correlative between the four drill sites (Figure F26). Felsic ash layers (tephra) appear to be relatively abundant at Sites U1439 and U1440 (larger sediment ponds) compared to more mafic ash layers at Sites U1441 and U1442 (smaller basins).

The switch to mixed clastic and siliceous ooze sedimentation (with well-preserved radiolarian and siliceous sponge spicules) during the Miocene reflects a relative rise in the carbonate compensation depth, which could have been either tectonically or paleoceanographically controlled. The carbonate-poor interval is more extensive in the deeper water sites (U1440 and U1441) compared to the shallower sites (U1439 and U1442).

At Sites U1440 and U1441, sediment was affected, to different extents, by local gravity redeposition and current reworking, which was probably tectonically triggered. Pumice-rich volcaniclastic sediment was reworked from the fault-controlled margins of the sediment ponds, especially at Sites U1440 and U1441. There is evidence of tectonic tilting, both prior to and during sediment accumulation (e.g., Site U1439). Postdepositional tilting of Oligocene sediment and associated fracturing was locally exploited by fluid flow and manganese oxide precipitation (Site U1442). Diagenetic effects include carbonate recrystallization, zeolite growth, and upward mobilization of manganese from the igneous crust into the sediment column.

Finally, the probable difference in age between the oldest sediment recovered (Eocene; $35 \mathrm{Ma}$ ), and the igneous basement based on comparisons with comparable well-dated fore-arc basalts and boninites in the region, indicates that a 7-15 million year hiatus may exist between cessation of volcanism and covering of the seafloor by pelagic carbonates in different areas. The likely explanation of such a hiatus is that the outer part of the fore arc that encompasses the four drill sites existed as a submerged bathymetric high that remained free of sediment accumulation until the tectonically controlled formation of the sediment ponds that still remain today.

\section{Structures}

Postmagmatic extension of the outer IBM fore arc resulted in the formation of asymmetric sedimentary basins such as, for example, the half-grabens at Sites U1439 and U1442. Along their eastern margins, these basins are bounded by westward-dipping normal faults. Sedimentation was mainly syntectonic. The lowermost sequence of the sedimentary units was tilted eastward by $\sim 20^{\circ}$. These tilted bedding planes were subsequently covered by subhorizontally deposited sedimentary beds. Based on biostratigraphic constraints, the minimum age of the oldest sediments is $\sim 35 \mathrm{Ma}$; the timing of the sedimentary unconformities lies between $\sim 27$ and $32 \mathrm{Ma}$.

At Sites U1440 and U1441, postmagmatic deformation resulted mainly in strike-slip faults possibly bounding the sedimentary basins. The sedimentary units within these basins were not significantly affected by postsedimentary tectonic tilting. Based on biostratigraphic ages, the minimum age of the basement-cover contact lies between $\sim 29.5$ and $32 \mathrm{Ma}$.

Overall, the postmagmatic tectonic structures observed during Expedition 352 reveal a multiphase tectonic evolution of the outer IBM fore arc. At Sites U1439 and U1442, shear with dominant reverse to oblique reverse displacement was localized along distinct 


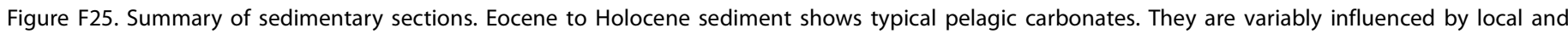
regional volcanism, leading to the alternating sequences of volcaniclastic-rich and nannofossil-pure lithologic units.

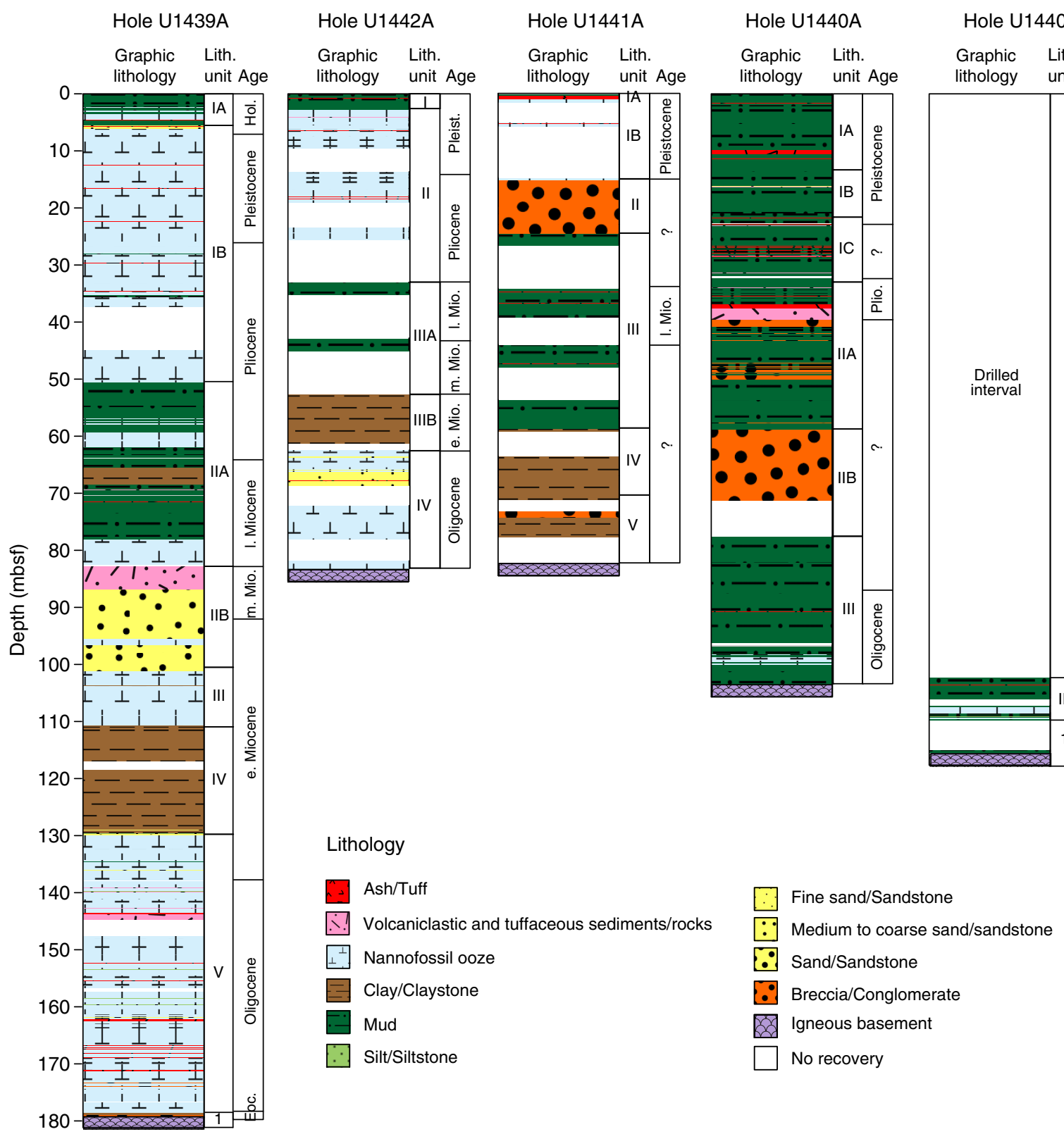

subhorizontal cataclastic shear zones as well as steeply dipping slickensides and shear fractures. These structures, forming within a contractional tectonic regime, were either reactivated as or crosscut by normal faults as well as strike-slip faults. Extension was also accommodated by steeply dipping to subvertical mineralized veins and extensional fractures. Faults observed at Sites U1440 and U1441 show mainly a strike-slip sense of motion.

\section{Physical properties and logging}

Basement rock $P$-wave velocities of $2.5-4.0 \mathrm{~km} / \mathrm{s}$ are observed in the sonic logs in Holes U1439C, U1440B, and U1442A. These velocities are $\sim 1.5 \mathrm{~km} / \mathrm{s}$ slower than observed logging velocities of normal ocean crust sites such as Holes 504B and 1256D (Becker et al., 1989; Swift et al., 2008). In contrast, porosities of the IBM and ocean crust sites are similar. Postcruise research will investigate these results, and the implications for IBM fore-arc crust and SSZ ophiolites as analogs for oceanic crust. 
Figure F26. Normalized ash abundance, Sites U1439-U1442. Note different amounts of felsic and mafic ash layers across the slope. Arrows mark the decrease and increase of felsic and mafic tephras, respectively.

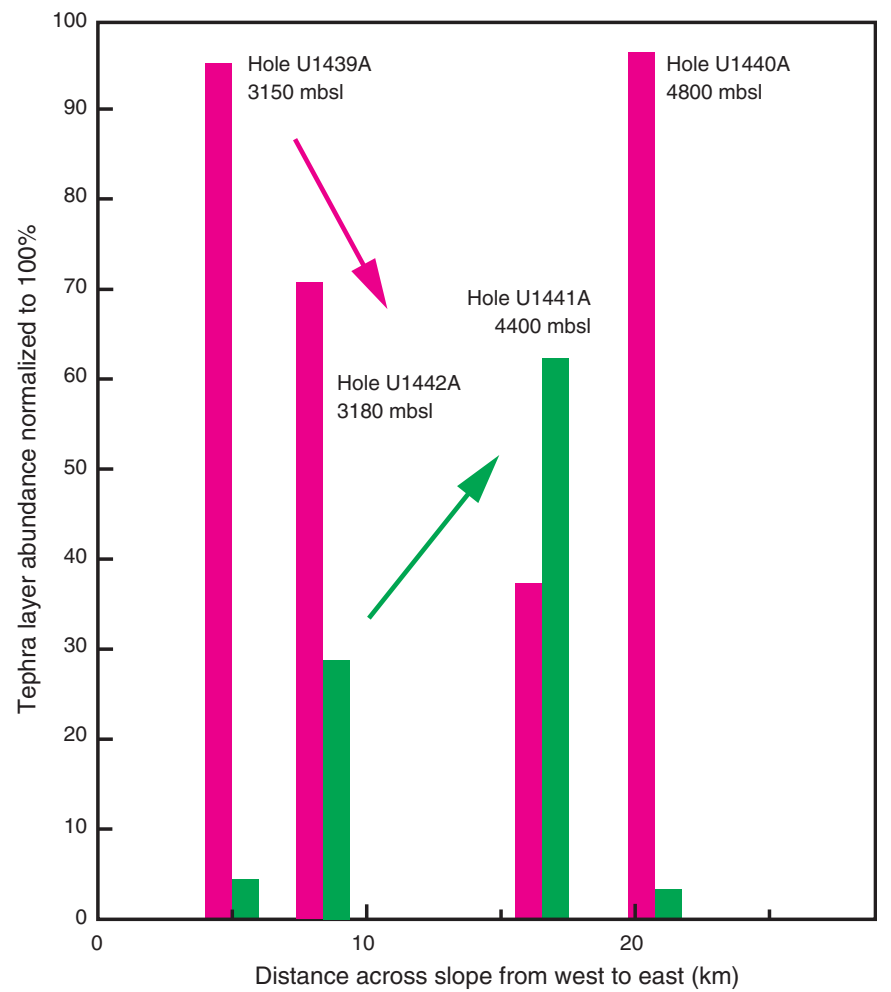

Felsic tephra Mafic tephra

\section{References}

Alabaster, T., Pearce, J.A., and Malpas, J., 1982. The volcanic stratigraphy and petrogenesis of the Oman ophiolite complex. Contributions to Mineralogy and Petrology, 81(3):168-183. http://dx.doi.org/10.1007/BF00371294

Becker, K., Sakai, H., Adamson, A.C., Alexandrovich, J., Alt, J.C., Anderson, R.N., Bideau, D., Gable, R., Herzig, P.M., Houghton, S., Ishizuka, H., Kawahata, H., Kinoshita, H., Langseth, M.G., Lovell, M.A., Malpas, J., Masuda, H., Merrill, R.B., Morin, R.H., Mottl, M.J., Pariso, J.E., Pezard, P., Phillips, J., Sparks, J., and Uhlig, S., 1989. Drilling deep into young oceanic crust, Hole 504B, Costa Rica Rift. Reviews of Geophysics, 27(1):79-102. http://dx.doi.org/10.1029/RG027i001p00079

Bédard, J.H., Lauzière, K., Tremblay, A., and Sangster, A., 1998. Evidence for forearc seafloor-spreading from the Betts Cove ophiolite, Newfoundland: oceanic crust of boninitic affinity. Tectonophysics, 284(3-4):233-245. http://dx.doi.org/10.1016/S0040-1951(97)00182-0

Bloomer, S.H., Taylor, B., MacLeod, C.J., Stern, R.J., Fryer, P., Hawkins, J.W., and Johnson, L., 1995. Early arc volcanism and the ophiolite problem: a perspective from drilling in the western Pacific. In Taylor, B., and Natland, J. (Eds.), Active Margins and Marginal Basins of the Western Pacific. Geophysical Monograph, 88:1-30. http://dx.doi.org/10.1029/GM088p0001

Cosca, M.A., Arculus, R.J., Pearce, J.A., and Mitchell, J.G., 1998. ${ }^{40} \mathrm{Ar} /{ }^{39} \mathrm{Ar}$ and $\mathrm{K}-\mathrm{Ar}$ geochronological age constraints for the inception and early evolution of the Izu-Bonin-Mariana arc system. Island Arc, 7(3):579-595. http://dx.doi.org/10.1111/j.1440-1738.1998.00211.x

Crawford, A.J., Falloon, T.J., and Green, D.H., 1989. Classification, petrogenesis and tectonic setting of boninites. In Crawford, A.J. (Ed.), Boninites and Related Rocks: London (Unwin Hyman), 1-49.

DeBari, S.M., Taylor, B., Spencer, K., and Fujioka, K., 1999. A trapped Philippine Sea plate origin for MORB from the inner slope of the Izu-Bonin
Trench. Earth and Planetary Science Letters, 174(1-2):183-197. http://dx.doi.org/10.1016/S0012-821X(99)00252-6

Dick, H.J.B., 1989. Abyssal peridotites, very slow spreading ridges and ocean ridge magmatism. In Saunders, A.D., and Norry, M.J. (Eds.), Magmatism in the Ocean Basins. Geological Society Special Publication, 42(1):71105. http://dx.doi.org/10.1144/GSL.SP.1989.042.01.06

Dilek, Y., and Flower, M.F.J., 2003. Arc-trench rollback and forearc accretion, 2. A model template for ophiolites in Albania, Cyprus, and Oman. In Dilek, Y., and Robinson, R.T. (Eds.), Ophiolites in Earth History. Geological Society Special Publication, 218:43-68. http://dx.doi.org/10.1144/GSL.SP.2003.218.01.04

Dilek, Y., Furnes, H., and Shallo, M., 2008. Geochemistry of the Jurassic Mirdita Ophiolite (Albania) and the MORB to SSZ evolution of a marginal basin oceanic crust. Lithos, 100(1-4):174-209. http://dx.doi.org/10.1016/j.lithos.2007.06.026

Hall, C.E., Gurnis, M., Sdrolias, M., Lavier, L.L., and Dietmar Müller, R., 2003. Catastrophic initiation of subduction following forced convergence across fracture zones. Earth and Planetary Science Letters, 212(1-2):15-30. http://dx.doi.org/10.1016/S0012-821X(03)00242-5

Hickey-Vargas, R., and Reagan, M.K., 1987. Temporal variation of isotope and rare earth element abundances in volcanic rocks from Guam: implications for the evolution of the Mariana Arc. Contributions to Mineralogy and Petrology, 97(4):497-508. http://dx.doi.org/10.1007/BF00375327

Ishikawa, T., Nagaishi, K., and Umino, S., 2002. Boninitic volcanism in the Oman ophiolite: implications for thermal condition during transition from spreading ridge to arc. Geology, 30(10):899-902. http://dx.doi.org/10.1130/0091-7613(2002)030<0899:BVITOO $>2.0 . C O ; 2$

Ishizuka, O., Kimura, J.-I., Li, Y.B., Stern, R.J., Reagan, M.K., Taylor, R.N., Ohara, Y., Bloomer, S.H., Ishii, T., Hargrove, U.S., III, and Haraguchi, S., 2006. Early stages in the evolution of Izu-Bonin arc volcanism: new age, chemical, and isotopic constraints. Earth and Planetary Science Letters, 250(1-2):385-401. http://dx.doi.org/10.1016/j.epsl.2006.08.007

Ishizuka, O., Tani, K., Reagan, M.K., Kanayama, K., Umino, S., Harigane, Y., Sakamoto, I., Miyajima, Y., Yuasa, M., and Dunkley, D.J., 2011. The timescales of subduction initiation and subsequent evolution of an oceanic island arc. Earth and Planetary Science Letters, 306(3-4):229-240. http://dx.doi.org/10.1016/j.epsl.2011.04.006

Jenner, F.E., and O'Neill, H.St.C., 2012. Analysis of 60 elements in 616 ocean floor basaltic glasses. Geochemistry, Geophysics, Geosystems, 13(2):Q02005. http://dx.doi.org/10.1029/2011GC004009

Johnson, L.E., and Fryer, P., 1990. The first evidence for MORB-like lavas from the outer Mariana forearc: geochemistry, petrography and tectonic implications. Earth and Planetary Science Letters, 100(1-3):304-316. http://dx.doi.org/10.1016/0012-821X(90)90193-2

Kamimura, A., Kasahara, J., Shinohara, M., Hino, R., Shiobara, H., Fujie, G., and Kanazawa, T., 2002. Crustal structure study at the Izu-Bonin subduction zone around $31^{\circ} \mathrm{N}$ : implications of serpentinized materials along the subduction plate boundary. Physics of the Earth and Planetary Interiors, 132(1-3):105-129. http://dx.doi.org/10.1016/S0031-9201(02)00047-X

Kanayama, K., Kitamura, K., and Umino, S., 2013. New geochemical classification of global boninites. IAVCEI 2013 Scientific Assembly Abstracts. (Poster 4W_1B-P13)

Kaneoka, I., Isshiki, N., and Zashu, S., 1970. K-Ar ages of the Izu-Bonin Islands. Geochemical Journal, 4(2):53-60. http://dx.doi.org/10.2343/geochemj.4.53

Kodaira, S., Noguchi, N., Takahashi, N., Ishizuka, O., and Kaneda, Y., 2010. Evolution from fore-arc oceanic crust to island arc crust: a seismic study along the Izu-Bonin fore arc. Journal of Geophysical Research: Solid Earth, 115(B9):B09102. http://dx.doi.org/10.1029/2009JB006968

Langmuir, C.H., Bender, J.F., and Batiza, R., 1986. Petrological and tectonic segmentation of the East Pacific Rise, $5^{\circ} 30^{\prime} \mathrm{N}-14^{\circ} 30^{\prime} \mathrm{N}$. Nature, 322(6078):422-429. http://dx.doi.org/10.1038/322422a0

Langmuir, C.H., Klein, E.M., and Plank, T., 1992. Petrological systematics of mid-ocean ridge basalts: constraints on melt generation beneath ocean ridges. In Morgan, J., Blackman, D., and Sinton, J. (Eds.), Mantle Flow and 
Melt Generation at Mid-Ocean Ridges. Geophysical Monograph, 71:183280. http://dx.doi.org/10.1029/GM071p0183

Le Bas, M.J., 2000. IUGS reclassification of the high-Mg and picritic volcanic rocks. Journal of Petrology, 41(10):1467-1470. http://dx.doi.org/10.1093/petrology/41.10.1467

Le Bas, M.J., Le Maitre, R.W., Streckeisen, A., Zanettin, B., and the IUGS Subcommission on the Systematics of Igneous Rocks, 1986. A chemical classification of volcanic rocks based on the total alkali-silica diagram. Journal of Petrology, 27(3):745-750. http://petrology.oxfordjournals.org/content/27/3/745.abstract

Meijer, A., Anthony, E., and Reagan, M., 1982. Petrology of volcanic rocks from the fore-arc sites. In Hussong, D.M., and Uyeda, S., Initial Reports of the Deep Sea Drilling Project, 60: Washington, DC (U.S. Government Printing Office), 709-729. http://dx.doi.org/10.2973/dsdp.proc.60.138.1982

Parkinson, I.J., Hawkesworth, C.J., and Cohen, A.S., 1998. Ancient mantle in a modern arc: osmium isotopes in Izu-Bonin-Mariana forearc peridotites. Science, 281(5385):2011-2013. http://dx.doi.org/10.1126/science.281.5385.2011

Pearce, J.A., Kempton, P.D., Nowell, G.M., and Noble, S.R., 1999. Hf-Nd element and isotope perspective on the nature and provenance of mantle and subduction components in western Pacific arc-basin systems. Journal of Petrology, 40(11):1579-1611. http://dx.doi.org/10.1093/petroj/40.11.1579

Pearce, J.A., Lippard, S.J., and Roberts, S., 1984. Characteristics and tectonic significance of supra-subduction zone ophiolites. In Kokelaar, B.P., and Howells, M.F. (Eds.), Marginal Basin Geology: Volcanic and Associated Sedimentary and Tectonic Processes in Modern and Ancient Arginal Basins. Geological Society Special Publication, 16(1):74-94. http://dx.doi.org/10.1144/GSL.SP.1984.016.01.06

Pearce, J.A. and Robinson, P.T., 2010. The Troodos ophiolitic complex probably formed in a subduction initiation, slab edge setting. Gondwana Research, 18(1):60-81. http://dx.doi.org/10.1016/j.gr.2009.12.003

Pearce, J.A., van der Laan, S.R., Arculus, R.J., Murton, B.J., Ishii, T., Peate, D.W., and Parkinson, I.J., 1992. Boninite and harzburgite from Leg 125 (Bonin-Mariana forearc): a case study of magma genesis during the initial stages of subduction. In Fryer, P., Pearce, J.A., Stokking, L.B., et al., Proceedings of the Ocean Drilling Program, Scientific Results, 125: College Station, TX (Ocean Drilling Program), 623-659. http://dx.doi.org/10.2973/odp.proc.sr.125.172.1992

Reagan, M.K., Hanan, B.B., Heizler, M.T., Hartman, B.S., and Hickey-Vargas, R., 2008. Petrogenesis of volcanic rocks from Saipan and Rota, Mariana Islands, and implications for the evolution of nascent island arcs. Journal of Petrology, 49(3):441-464. http://dx.doi.org/10.1093/petrology/egm087

Reagan, M.K., Ishizuka, O., Stern, R.J., Kelley, K.A., Ohara, Y., Blichert-Toft, J., Bloomer, S.H., Cash, J., Fryer, P., Hanan, B.B., Hickey-Vargas, R., Ishii, T., Kimura, J.-I., Peate, D.W., Rowe, M.C., and Woods, M., 2010. Fore-arc basalts and subduction initiation in the Izu-Bonin-Mariana system. Geochemistry, Geophysics, Geosystems, 11(3):Q03X12. http://dx.doi.org/10.1029/2009GC002871

Reagan, M.K., McClelland, W.C., Girard, G., Goff, K.R., Peate, D.W., Ohara, Y., and Stern, R.J., 2013. The geology of the southern Mariana fore-arc crust: implications for the scale of Eocene volcanism in the western Pacific.
Earth and Planetary Science Letters, 380:41-51.

http://dx.doi.org/10.1016/j.epsl.2013.08.013

Reagan, M.K., Pearce, J.A., Petronotis, K., Almeev, R., Avery, A.A., Carvallo, C., Chapman, T., Christeson, G.L., Ferré, E.C., Godard, M., Heaton, D.E., Kirchenbaur, M., Kurz, W., Kutterolf, S., Li, H.Y., Li, Y., Michibayashi, K., Morgan, S., Nelson, W.R., Prytulak, J., Python, M., Robertson, A.H.F., Ryan, J.G., Sager, W.W., Sakuyama, T., Shervais, J.W., Shimizu, K., and Whattam, S.A., 2015. Expedition 352 methods. In Reagan, M.K., Pearce, J.A., Petronotis, K., and the Expedition 352 Scientists, Izu-Bonin-Mariana Fore Arc. Proceedings of the International Ocean Discovery Program, 352: College Station, TX (International Ocean Discovery Program). http://dx.doi.org/10.14379/iodp.proc.352.102.2015

Rudnick, R.L., 1995. Making continental crust. Nature, 378(6557):571-578. http://dx.doi.org/10.1038/378571a0

Shervais, J.W., 1982. Ti-V plots and the petrogenesis of modern and ophiolitic lavas. Earth and Planetary Science Letters, 59(1):101-118. http://dx.doi.org/10.1016/0012-821X(82)90120-0

Stern, R.J., 2004. Subduction initiation: spontaneous and induced. Earth and Planetary Science Letters, 226(3-4):275-292. http://dx.doi.org/10.1016/j.epsl.2004.08.007

Stern, R.J., and Bloomer, S.H., 1992. Subduction zone infancy: examples from the Eocene Izu-Bonin-Mariana and Jurassic California arcs. Geological Society of America Bulletin, 104(12):1621-1636. http://dx.doi.org/10.1130/0016-7606(1992)104<1621:SZIEFT >2.3. $\mathrm{CO} ; 2$

Stern, R.J., Fouch, M.J., and Klemperer, S., 2003. An overview of the IzuBonin-Mariana subduction factory. In Eiler, J. (Ed.), Inside the Subduction Factory. Geophysical Monograph, 138:175-222. http://dx.doi.org/10.1029/138GM10

Stern, R.J., Reagan, M., Ishizuka, O., Ohara, Y., and Whattam, S., 2012. To understand subduction initiation, study forearc crust: to understand forearc crust, study ophiolites. Lithosphere, 4(6):469-483. http://dx.doi.org/10.1130/L183.1

Swift, S., Reichow, M., Tikku, A., Tominaga, M., and Gilbert, L., 2008. Velocity structure of upper ocean crust at Ocean Drilling Program Site 1256. Geochemistry, Geophysics, Geosystems, 9(10):Q10O13. http://dx.doi.org/10.1029/2008GC002188

Tatsumi, Y., and Stern, R.J., 2006. Manufacturing continental crust in the subduction factory. Oceanography, 19(4):104-112. http://dx.doi.org/10.5670/oceanog.2006.09

Taylor, R.N., Nesbitt, R.W., Vidal, P., Harmon, R.S., Auvray, B., and Croudace, I.W., 1994. Mineralogy, chemistry, and genesis of the boninite series volcanics, Chichijima, Bonin Islands, Japan. Journal of Petrology, 35(3):577617. http://dx.doi.org/10.1093/petrology/35.3.577

Wood, D.A., Marsh, N.G., Tarney, J., Joron, J.-L., Fryer, P., and Treuil, M., 1982. Geochemistry of igneous rocks recovered from a transect across the Mariana Trough, arc, fore-arc, and trench, Sites 453 through 461, Deep Sea Drilling Project Leg 60. In Hussong, D.M., Uyeda, S., et al., Initial Reports of the Deep Sea Drilling Project, 60: Washington (U.S. Government Printing Office), 611-645. http://dx.doi.org.10.2973/dsdp.proc.60.133.1982

Yumul, G.P., 1996. Varying mantle sources of supra-subduction zone ophiolites: REE evidence from the Zambales Ophiolite Complex, Luzon, Philippines. Tectonophysics, 262(1-4):243-262. http://dx.doi.org/10.1016/0040-1951(96)00013-3 